\title{
AVALIAÇÃO CLÍNICA E LABORATORIAL DO TRATAMENTO DA ESTOMATITE PROTÉTICA ATRAVÉS DE PRODUTOS NATURAIS
}

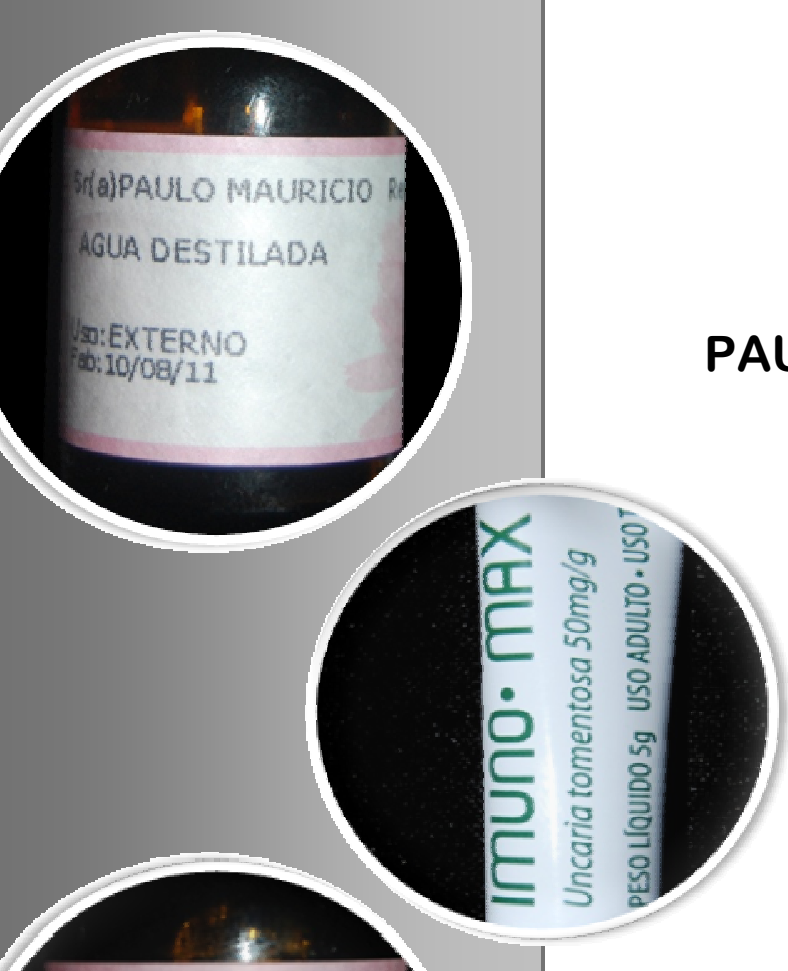

PAULO MAURÍCIO BATISTA DA SILVA

Tese apresentada à Faculdade de Odontologia de Bauru, da Universidade de São Paulo, como parte dos requisitos necessários para obtenção do título de Doutor em Ciências, no Programa de Ciências Odontológicas Aplicadas, na área de concentração em Reabilitação Oral.

Orientador: Prof. Dr. Vinícius Carvalho Porto 



\section{UNIVERSIDADE DE SÃO PAULO \\ FACULDADE DE ODONTOLOGIA DE BAURU}

PAULO MAURÍCIO BATISTA DA SILVA

Avaliação clínica e laboratorial do tratamento da estomatite protética através de produtos naturais.

Bauru

2013 



\section{PAULO MAURÍCIO BATISTA DA SILVA}

\section{Avaliação clínica e laboratorial do tratamento da estomatite protética através de produtos naturais.}

Tese apresentada à Faculdade de Odontologia de Bauru, da Universidade de São Paulo, como parte dos requisitos necessários para obtenção do título de Doutor em Ciências, no Programa de Ciências Odontológicas Aplicadas, na área de concentração em Reabilitação Oral.

Orientador: Prof. Dr. Vinícius Carvalho Porto 


\section{Silva, Paulo Maurício Batista da}

Si38a Avaliação clínica e laboratorial do tratamento da estomatite protética através de produtos naturais/ Paulo Maurício Batista da Silva. -- Bauru, 2013.

116 p.:il.; $31 \mathrm{~cm}$.

Tese (Doutorado) -- Faculdade de Odontologia de Bauru, Universidade de São Paulo.

Orientador: Prof. Dr. Vinícius Carvalho Porto

Autorizo, exclusivamente para fins acadêmicos e científicos, a reprodução total ou parcial desta dissertação/tese, por processos fotocopiadores e outros meios eletrônicos.

Assinatura:

Data:

Comitê de Ética da FOB-USP

Protocolo $n^{0}:$ 078/2010

Data: $27 / 08 / 2010$ 


\section{Dedicatória}

Dedico e agradeço este trabalho às pessoas que são imprescindíveis na minha vida, as quais, sem elas, os meus objetivos e ambições são inatingíveis.

Aos meus pais, meus eternos e maiores incentivadores. À minha amada mãe, Valdeisa, fonte inesgotável de amor e generosidade, cujo caminho de retidão guiou meus passos até aqui. Ao meu pai, Adelino, o amor aos filhos e seu profissionalismo serão sempre exemplos pra mim. Tenho certeza que, mesmo depois de concluir um doutorado, os ensinamentos mais valiosos que possuo ainda são aqueles que vocês me transmitiram. Muito obrigado por tudo.

À Patrícia, minha amantíssima namorada, minha companheira de todas as horas mesmo à distância e meu ponto de equilíbrio. Seu amor sincero, sua ajuda e sua forma positivista de enfrentar as dificuldades foram incentivos determinantes para que eu pudesse concluir este trabalho e o doutoramento. Espero tê-la na minha vida sempre e para sempre. Amo você. 



\section{Agradecimentos $\mathcal{E}_{\text {speciais }}$}

Ao mestre, orientador e, sobretudo, amigo, Prof. Dr. Vinícius Carvalho Porto, meu muito obrigado de coração. Tive a sorte e o prazer de ter sido orientado por você desde 2004, ano que cheguei a Bauru. Após 9 anos de FOB, posso concluir que poucos foram tão agraciados como eu dentro desta faculdade, pois tive o privilégio de ter um orientador amigo, generoso e dedicado à profissão. Agradeço a sua confiança e todo o seu apoio durante a realização desta pesquisa.

Aos meus irmãos, André e Cláudia, verdadeiros companheiros de todas as horas. Em especial, ao André que, no momento mais difícil, fez jus a palavra irmão e me proporcionou, entre outras coisas, um espaço tranquilo, no qual fui capaz de retornar o foco a este trabalho. Todo o meu amor e gratidão a vocês.

Aos meus sobrinhos, Fernanda, Felipe e Bia, por me oferecerem momentos de imensa alegria sempre que estamos juntos.

Aos pacientes participantes desta pesquisa, pela colaboração e disponibilidade, sem os quais esta pesquisa seria inviável.

Aos ex-alunos da Iniciação científica, Isabela Medeiros e Huascar Zapata, pela fundamental ajuda na execução desta pesquisa. 



\section{Agradecimentos}

Aos meus colegas do doutorado, Vinícius, Marcela, Marcos Lanza, Bruno, Priscila, Fábio e, em especial, ao meu amigo Marcelo Ramos, pela companhia, pelas trocas de experiência e amizade.

À Faculdade de Odontologia de Bauru - USP, representada por seu Diretor Prof. Dr. José Carlos Pereira, e à sua Comissão de Pós-Graduação, representada pelo Prof. Dr. Paulo César Conti.

A todos os Professores do Departamento de Prótese da Faculdade de Odontologia de Bauru - USP, Prof. Dr. Accácio Lins do Valle, Prof. Dr. Carlos Dos Reis Pereira de Araújo, Prof. Dr. Gerson Bonfante, Prof. Dr. José Henrique Rubo, Profa. Dra. Ana Lúcia, Profa. Dra. Simone Soares, Profa. Dra. Lucimar Falavinha, Prof. Dr. Luiz Fernando Pegoraro, Prof. Dr. Milton Carlos Salvador (in memorian), Prof. Dr. Paulo César Rodrigues Conti, Prof. Dr. Paulo Martins Ferreira, Prof. Dr. Pedro César Garcia e Prof. Dr. Wellington Cardoso Bonachela e Prof. Dr. Renato de Freitas, pelos seus ensinamentos enriquecedores. Particularmente, agradeço a Profa. Dra. Karin Hermana Neppelenbroek, por todas as vezes que interrompeu suas atividades e respondeu minhas dúvidas, e pelo financiamento de parte desta pesquisa.

Aos funcionários do Departamento de Prótese Dentária da Faculdade de Odontologia de Bauru - USP, Marcelo Giatti, Reivanildo, Walquíria, Cláudia e Débora, pela solicitude e disponibilidade.

Aos funcionários do Centro Integrado de Pesquisa - CIP da Faculdade de Odontologia de Bauru - USP, Dona Neusa, Renato e Rafaela, pela prestatividade. Em especial, agradeço ao Marcelo Milanda e a Márcia Graef, pela competência, companheirismo, ajuda e conhecimentos compartilhados. 

Aos abrigos Casa do Pão de Santo Antônio e Casa do Pão da Igreja dos Capuchinhos, ambos em Belém do Pará, os quais acolheram o meu projeto de pesquisa e ofereceram as instalações para o seu desenvolvimento.

Ao Hospital de Aeronáutica de Belém - HABE, na pessoa do Chefe da Divisão Odontológica, Coronel Corrêa, pela compreensão nos momentos que precisei me ausentar por conta da realização desta pesquisa.

À Profa. Ms. Talita Tartari pela colaboração na análise estatística deste trabalho.

À ACECIL, pela colaboração na esterilização dos espécimes de resina acrílica utilizados nesta pesquisa.

Ao Conselho Nacional de Desenvolvimento Científico e Tecnológico (CNPq) pelo auxílio financeiro concedido, o qual foi fundamental para conclusão deste curso. 



\section{RESUMO}

O aumento da resistência aos antifúngicos convencionais e os possíveis efeitos colaterais destes fármacos têm estimulado pesquisas sobre produtos naturais com potencial antimicrobiano e baixa toxicidade. Assim, o objetivo desta pesquisa foi realizar uma avaliação clínica e laboratorial do tratamento da estomatite protética (EP) através de produtos naturais, por meio de cultura micológica quantitativa, de microscopia confocal e de análise das propriedades superficiais de uma resina acrílica. Em todas as avaliações, os grupos experimentais foram divididos de acordo com as seguintes substâncias: G1 - água destilada estéril; G2 - nistatina; G3 extrato alcoólico de própolis a 20\%; G4 - gel de Punica granatum Linné; G5 - gel de Uncaria tomentosa (Imuno-Max Gel). Para a cultura micológica quantitativa, 30 pacientes diagnosticados com EP utilizaram os seus respectivos medicamentos três vezes por dia, durante 14 dias, associados à escovação das próteses com dentifrício. Nas avaliações, foram coletados materiais das áreas eritematosas da mucosa palatina e das áreas correspondentes na prótese total superior. Este procedimento foi realizado antes do tratamento (T0), após 14 dias do início do tratamento (T1) e 30 dias após a suspensão do uso dos medicamentos (T2). Os dados obtidos foram submetidos ao teste não-paramétrico de Friedman para comparações intragrupos e ao teste de Kruskal-Wallis para comparações intergrupos. Para análise através de microscopia confocal, 30 espécimes de uma resina acrílica termopolimerizável foram inoculados com $C$. albicans para a formação do biofilme e, em seguida, imersos em sua respectiva droga. Os biofilmes remanescentes sobre os espécimes foram corados através de fluorocromos indicadores de viabilidade celular. Os dados obtidos foram analisados através do teste não paramétrico de Kruskal-Wallis e do pós-teste de comparação múltipla de Dunn. Para análise das propriedades superficiais, 50 espécimes de uma resina acrílica termopolimerizável foram fabricados, polidos e testados para a verificação inicial da rugosidade e da microdureza (T0). A seguir, cada espécime foi imerso na sua correspondente substância por 24 horas. Após 14 dias de imersão (T1), as propriedades superficiais dos espécimes foram novamente mensuradas. A variação intragrupos na rugosidade e na microdureza foi avaliada através do teste $t$ pareado. 

A avaliação intergrupos, quanto ao efeito dos produtos testados na rugosidade e na microdureza, foi realizada através da análise de variância (ANOVA), seguida de teste de Tukey. Para todos os testes deste estudo foi considerado um nível de significância de $5 \%(p<0,05)$. De acordo com os resultados, foi possível concluir que o gel de $P$. granatum Linné exibiu propriedades superiores em relação aos produtos naturais testados. Esta substância apresentou um efeito mais completo, uma vez que, associada à escovação manual, proporcionou a maior redução da contaminação fúngica da mucosa palatina de pacientes com EP em longo prazo, além de promover, in vitro, a perda total da viabilidade celular e maior remoção das células fúngicas em biofilmes. Por fim, este produto não alterou significantemente, in vitro, a rugosidade e a microdureza da resina acrílica testada.

Palavras-chave: Antifúngicos. Prótese Total. Estomatite sob Prótese. Microscopia Confocal. Candida albicans. 



\section{ABSTRACT \\ Clinical and laboratory evaluation of denture stomatitis treatment using natural products.}

The increased resistance to conventional antifungal drugs and their possible side effects have stimulated research on natural products with antimicrobial activity and low toxicity. This study comprised a clinical and laboratory evaluation of the treatment of denture stomatitis (DS) using natural products by quantitative mycological culture, confocal microscopy and analysis of surface properties of an acrylic resin. In all evaluations, the experimental groups were divided according to the following substances: G1 - sterile distilled water; G2 - nystatin (Micostatin); G3 - 20\% propolis alcoholic extract; G4 - P. granatum Linné gel; G5 - Uncaria tomentosa gel (ImunoMax Gel). For quantitative mycological culture, 30 patients diagnosed with DS used their respective medicines three times a day for 14 days, associated with denture brushing with dentifrice. For the analysis, material was collected from erythematous areas of the palatal mucosa and from corresponding areas on the maxillary denture. This procedure was performed before treatment (T0), at 14 days after treatment onset (T1) and 30 days after interrupting the use of drugs (T2). Data were analyzed by the non-parametric Friedman test for intragroup comparisons and Kruskal-Wallis test for intergroup comparisons. For analysis by confocal microscopy, 30 specimens of a polymerized acrylic resin were inoculated with $C$. albicans for biofilm development and then immersed in the respective drugs. The remaining biofilms on the specimens were stained using fluorochrome indicators of cell viability. Data were analyzed by non-parametric Kruskal-Wallis test and Dunn's multiple comparison post-hoc test. For the analysis of surface properties, 50 specimens of polymerized acrylic resin were fabricated, polished and tested for initial verification of roughness and microhardness (TO). Then, the specimens were individually immersed in the respective drugs for 24 hours. After 14 days of immersion (T1), the surface properties of the specimens were measured again. The intragroup variation in roughness and microhardness was evaluated by the paired t-test. The intergroup evaluation as to the effect of tested products on roughness and microhardness was performed by analysis of variance (ANOVA) followed by Tukey test. All tests in this 

study considered a significance level of $5 \%(p<0.05)$. According to the results, it was concluded that $P$. granatum Linné gel exhibited superior properties compared to the natural products tested. This substance showed a more thorough effect, since it provided the greatest long-term reduction of fungal contamination of the palatal mucosa of patients with DS when associated with manual brushing, besides promoting total loss of cell viability and increased removal of fungal cells in biofilms in vitro. Finally, in vitro, this drug did not significantly change the roughness and hardness of the acrylic resin tested.

Key words: Antifungal drugs. Complete denture. Denture stomatitis. Confocal microscopy. Candida albicans. 



\section{LISTA DE ILUSTRAÇÕES}

Figura 1 - Sequência padrão de análise dos 6 campos dos espécimes no microscópio confocal.

Figura 2 - Imagens do biofilme de C. albicans sobre resina acrílica termopolimerizável tratado com água destilada por 1 minuto através do microscópio confocal

Figura 3 - Imagens do biofilme de C. albicans sobre resina acrílica termopolimerizável após o tratamento com nistatina por 1 minuto através do microscópio confocal 69

Figura 4 - Imagens do biofilme de C. albicans sobre resina acrílica termopolimerizável após o tratamento com extrato alcoólico de própolis a $20 \%$ por 1 minuto através do microscópio confocal.

Figura 5 - Imagens do biofilme de $C$. albicans sobre resina acrílica termopolimerizável após o tratamento com gel de $P$. granatum Linné por 1 minuto através do microscópio confocal

Figura 6 - Imagens do biofilme de C. albicans sobre resina acrílica termopolimerizável após o tratamento com gel de $U$. tomentosa por 1 minuto através do microscópio confocal. 



\section{LISTA DE TABELAS}

Tabela 1 - Distribuição dos grupos de acordo com as substâncias testadas.

Tabela 2 - Mediana e desvio interquarlítico (DI) utilizados na comparação intragrupos (Friedman) e intergrupos (Kruskal-Wallis) nos tempos avaliados para as células coletadas na mucosa do palato (UFC/ml)

Tabela 3 - Mediana e desvio interquarlítico (DI) utilizados na comparação intragrupos (Friedman) e intergrupos (Kruskal-Wallis) nos tempos avaliados para as células coletadas na superfície interna da prótese (UFC/ml) 66

Tabela 4 - Mediana e desvio interquarlítico (DI) utilizados na análise de teste de Kruskal-Wallis com post-hoc de Dunn para comparação intergrupos em relação ao número de células viáveis, não viáveis e total de células

Tabela 5 - Médias e desvios padrão (DP) utilizados na comparação intragrupos da rugosidade superficial dos espécimes antes (T0) e depois (T1) das aplicações dos produtos testados (Teste t pareado)

Tabela 6 - Médias e desvios padrão (DP) utilizados na comparação intragrupos da microdureza superficial dos espécimes antes (T0) e depois (T1) das aplicações dos produtos testados (Teste t pareado)

Tabela 7 - Médias e desvios padrão (DP) utilizados na análise de variância (ANOVA) para comparar a rugosidade e a microdureza dos espécimes no primeiro dia de avaliação (T0)

Tabela 8 - Médias e desvios padrão utilizados na análise (ANOVA) e Teste de Tukey para comparar a rugosidade e a microdureza dos espécimes no décimo quarto dia de avaliação (T1). 



\section{LISTA DE ABREVIATURAS E SIGLAS}

- $\quad E P=$ estomatite protética

- $\quad$ sp. = espécie

- $\quad$ spp. = espécies

- C. albicans = Candida albicans

- et al = e colaboradores

- $\%=$ por cento

- U. tomentosa = Uncaria tomentosa

- $\mathrm{mg} / \mathrm{kg}=$ miligramas por quilo

- $D N A=$ ácido desoxirribonucleico

- $\mathrm{COX}-1$ = enzima cicloxigenase-1

- $\mathrm{COX}-2$ = enzima cicloxigenase-2

- $S$. mutans $=$ Streptococcus mutans

- DENV-Ag = kit de detecção do antígeno do vírus da dengue

- TNF- $\alpha=$ fator de necrose tumoral- $\alpha$

- IFN- $\alpha=$ interferon- $\alpha$

- $\mathrm{IL}-6=$ do interleucina-6

- $\mathrm{IL}-10=$ interleucina-10

- C. guilliermondii = Candida guilliermondii

- C. tropicalis = Candida tropicalis

- $\quad$. granatum linné = Punica granatum Linné

- $\mathrm{mg} / \mathrm{L}=$ miligramas por litro

- S. aureus = Staphylococcus aureus

- $\mathrm{v} / \mathrm{v}=$ volume por volume

- $\quad$ S. sangui $=$ Streptococcus sangui

- $\quad$ S. mitis $=$ Streptococcus mitis

- D.O.U = Diário Oficial da União

- $\mathrm{n}^{\circ}=$ número

- $\mathrm{RNA}=$ ácido ribonucleioco

- A. montana = Arnica montana

- $M G=$ Minas Gerais

- $\mathrm{RS}=$ Rio Grande do Sul 

- $\mathrm{BA}=$ Bahia

- $\mathrm{CIM}=$ Concentração inibitória mínima

- $\quad \mathrm{UFC} / \mathrm{mL}=$ unidades formadoras de colônias por mililitro

- PAS = do inglês "Periodic acid-Schiff stain"

- $\mathrm{MEV}=$ microscopia eletrônica de varredura

- $\mathrm{RS}=$ rugosidade superficial

- $\mathrm{DK}=$ dureza Knoop

- $E L S=$ energia livre de superfície

- $P M M A=$ polimetilmetacrilato

- $\mathrm{G}=$ grupos

- $\mathrm{UI} / \mathrm{mL}=$ unidades internacionais por mililitro

- $\min =$ minutos

- $\mathrm{mL}=$ mililitro

- $\mathrm{mm}=$ milímetros

- $\mathrm{Kg}=$ quilo

- $\mathrm{T}=$ tempo

- $\mu \mathrm{L}=$ microlitro

- $\mathrm{kgf}=$ quilograma-força

- $\mathrm{SC}=$ Santa Catarina

- $\mu \mathrm{m}=$ micrômetro

- $\mathrm{mm} / \mathrm{s}=$ milímetros por segundo

- $\mathrm{ATCC}=$ do ingles "American Type Culture Collection"

- $\mathrm{TSB}=$ caldo de soja trípico

- $\mathrm{PBS}=$ solução de tampão fosfato

- $\mathrm{C}=$ Celsius

- ${ }^{\circ}=$ graus

- $\quad r p m=$ rotações por minuto

- $\mathrm{nm}=$ nanômetro

- $g=$ gramas

- $\mathrm{ADA}=$ do inglês "American Dental Association"

- ISO = do inglês "International Organization for Standardization"

- $p=$ nível de significância

- $\quad \mathrm{DI}=$ desvio interqualítico

- $\mathrm{DP}=$ desvio padrão 



\section{SUMÁRIO}

1 INTRODUÇÃO E SÍNTESE BIBLIOGRÁFICA …...................................17

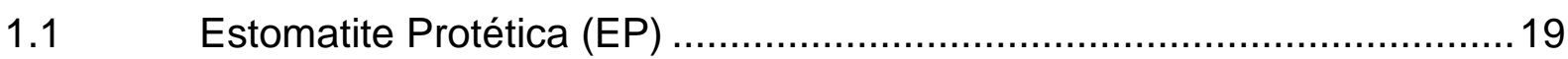

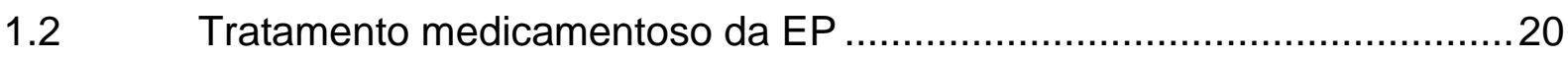

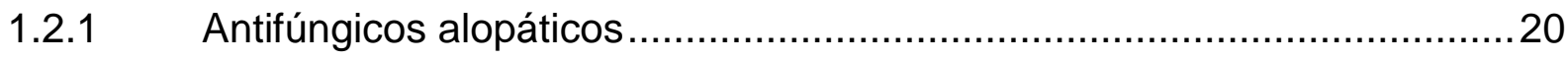

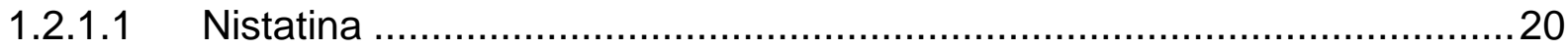

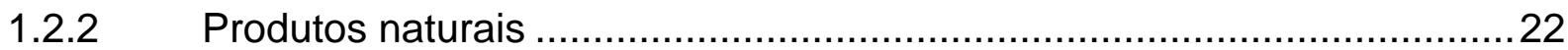

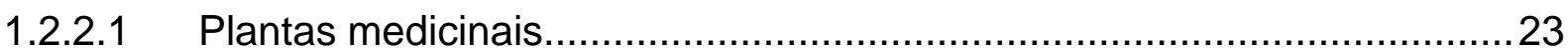

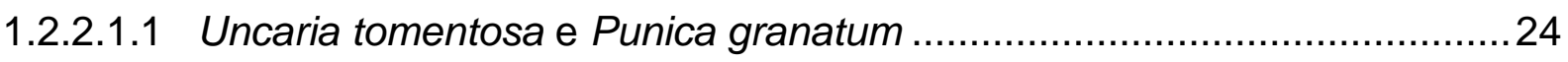

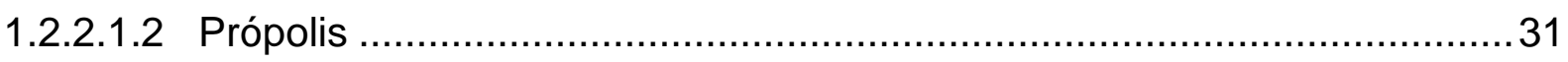

1.3 Análise dos efeitos de substância antimicrobianas sobre

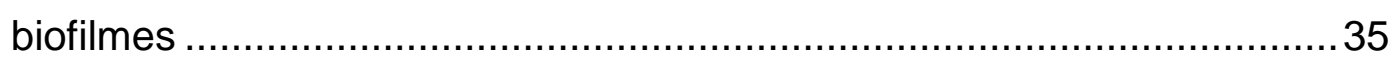

1.4 Alterações superficiais em resinas acrílicas causadas por

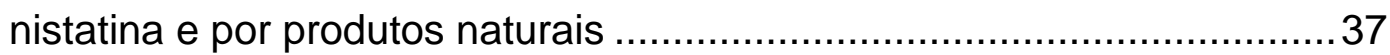

2 PROPOSIÇÃO

3 MATERIAL E MÉTODOS

3.1 Avaliação clínica do efeito antifúngico de produtos naturais no tratamento da EP. 47

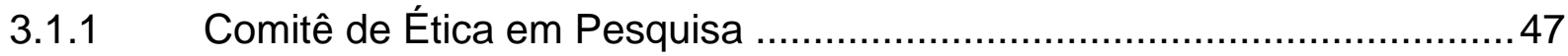

3.1.2 Anamnese e exame clínico ........................................................... 47

3.1.3 Critérios para a seleção da amostra..................................................... 48

3.1.4 Estabelecimento dos grupos de estudo................................................. 48

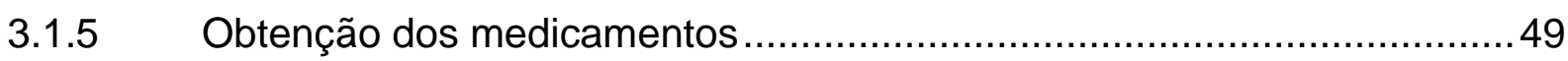

3.1.5.1 Nistatina (Micostatin) e gel de U. tomentosa (Imuno-Max)...................... 49

3.1.5.2 Extrato alcoólico de Própolis a 20 ........................................................49

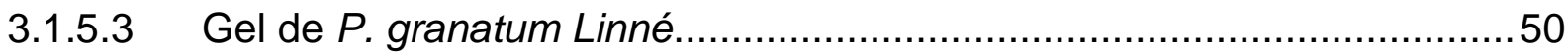

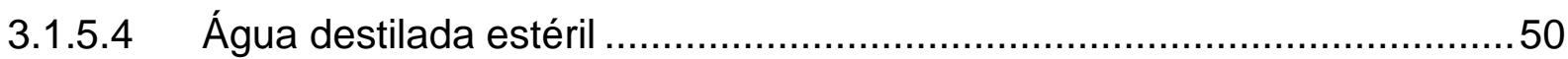

3.1.6 Avaliação clínica dos tratamentos testados...........................................50

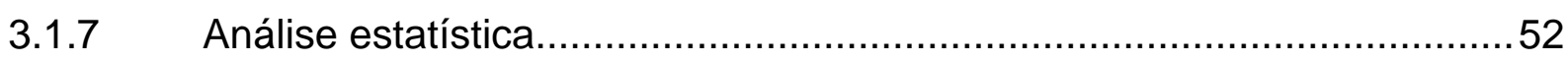



3.2 Avaliação do efeito antifúngico de produtos naturais sobre biofilmes de $C$. albicans em uma resina acrílica

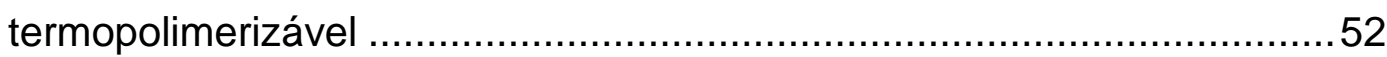

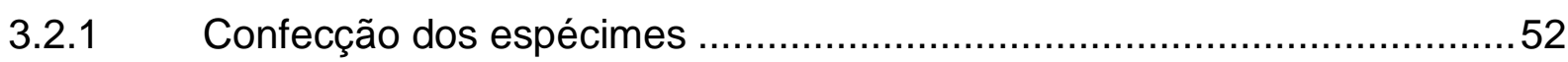

3.2.1.1 Confecção dos padrões de silicona...................................................52

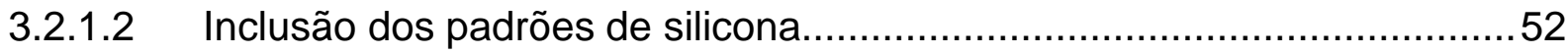

3.2.1.3 Preenchimento dos moldes, termopolimerização e acabamento dos bastões de resina acrílica ..........................................53

3.2.1.4 Lixamento dos bastões de resina acrílica, avaliação da rugosidade superficial, seccionamento e esterilização dos

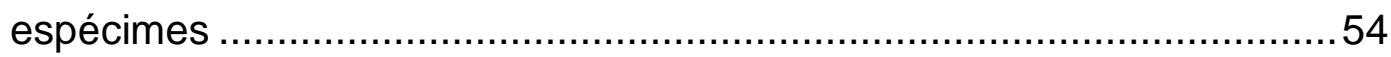

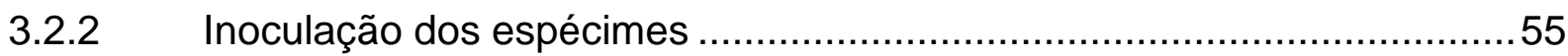

3.2.2.1 Micro-organismos e condições de crescimento .....................................55

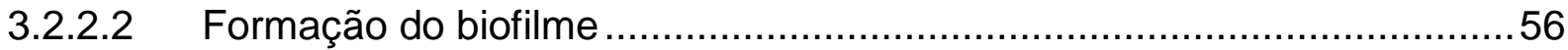

3.2.3 Aplicação das substâncias testadas..................................................57

3.2.4 Estabelecimento dos grupos de estudo...........................................57

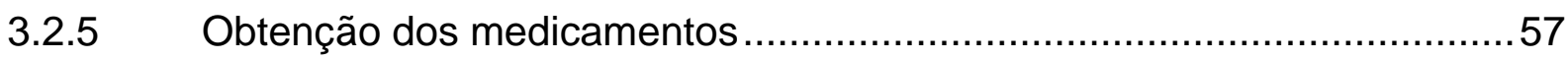

3.2.6 Processamento dos espécimes para microscopia

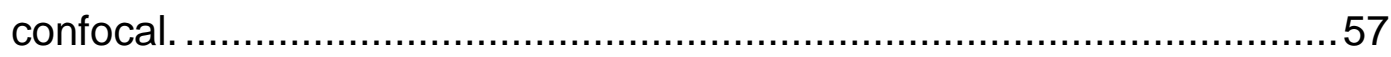

3.2.7 Análise dos espécimes no microscópio confocal ..................................58

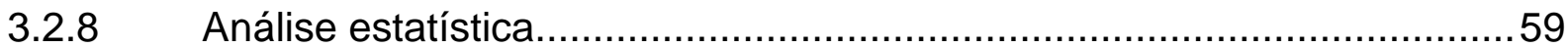

3.3 Avaliação laboratorial do efeito de produtos naturais sobre a rugosidade superficial e na microdureza de uma resina

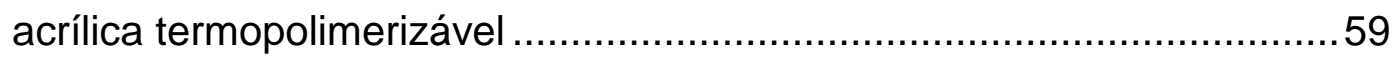

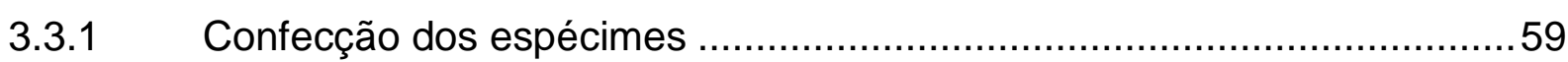

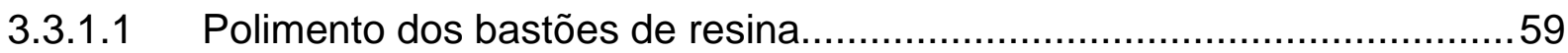

3.3.1.2 Obtenção dos espécimes de resina acrílica e

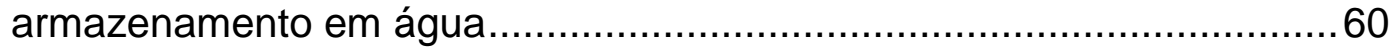

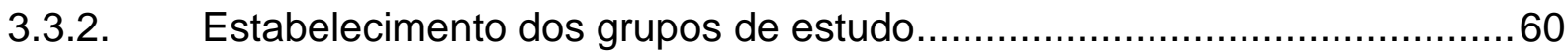

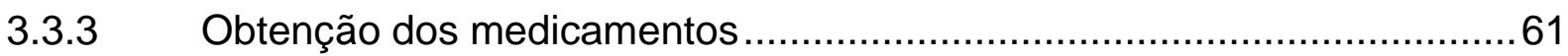

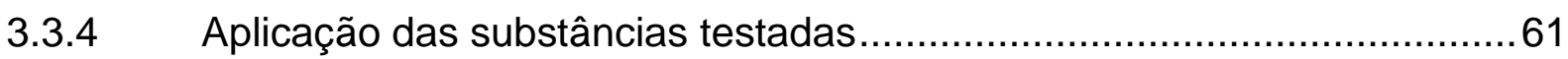

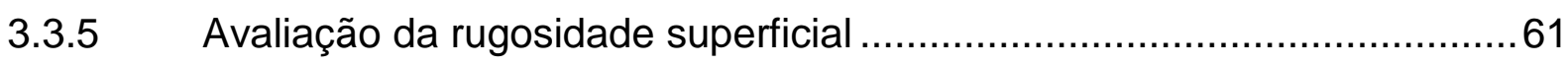

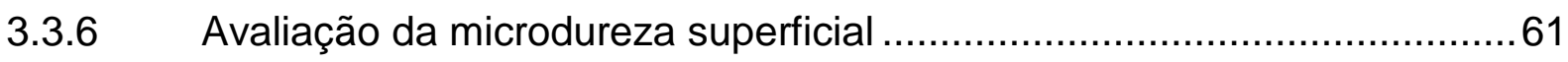

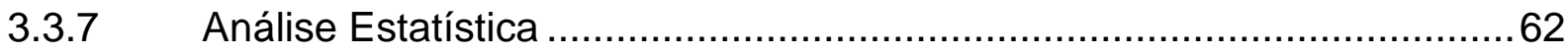



4.1 Avaliação clínica do efeito antifúngico de produtos

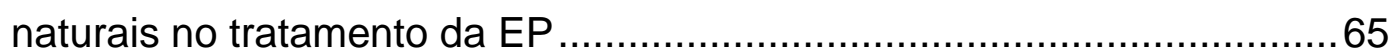

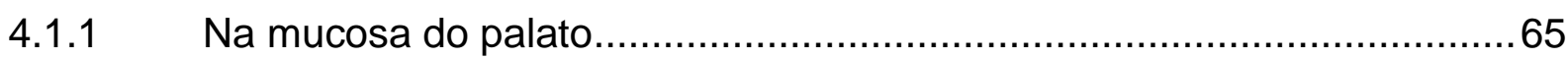

4.1.2. Na superfície interna da prótese................................................66

4.2 Avaliação do efeito antifúngico de produtos naturais sobre biofilmes de $C$. albicans em uma resina acrílica termopolimerizável ........................................................................67 67

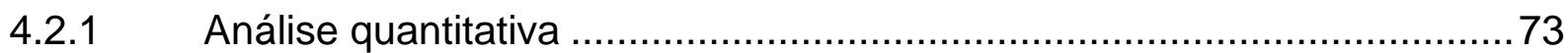

4.3 Avaliação laboratorial do efeito de produtos naturais sobre a rugosidade superficial e na microdureza de uma resina acrílica termopolimerizável .......................................................... 74

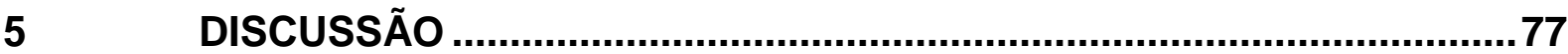

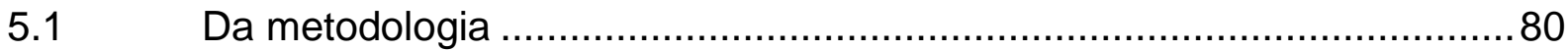

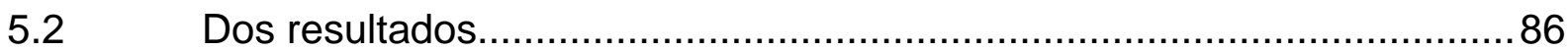

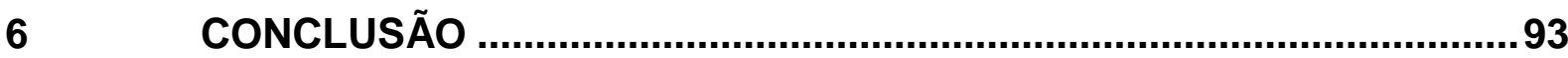

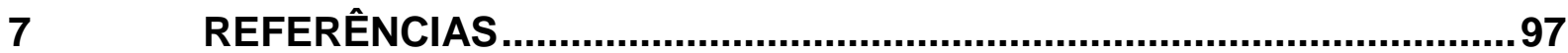

APÊNDICES............................................................................... 109 





\section{Introdução e síntese bibliográfica}

\subsection{Estomatite Protética (EP)}

A candidose bucal é uma inflamação local mucosa e oportunista, comum especialmente em indivíduos idosos e/ou usuários de prótese total ou parcial removível, e sua incidência tem aumentado nos últimos anos (CUMMING et al., 1990).

A estomatite protética (EP), considerada uma das formas de candidose bucal, é definida como um processo inflamatório na mucosa subjacente a uma prótese total ou parcial removível (RAMAGE et al., 2005), geralmente associada à presença do fungo Candida albicans (BARBEAU et al., 2003; RAMAGE et al., 2005).

Clinicamente, a EP apresenta-se como uma doença recorrente, que afeta o palato de cerca de $2 / 3$ dos usuários de prótese removível superior. É mais comum em mulheres e indivíduos imunodeficientes, e sua prevalência aumenta com a idade (ARENDORF e WALKER, 1987).

A EP afeta, na maioria dos casos, a mucosa que reveste o palato duro. Frequentemente é assintomática, porém, em casos mais graves, a mucosa pode mostrar-se hemorrágica e o paciente pode sentir prurido, queimação, inchaço, sintomatologia dolorosa, sabor desagradável, bem como apresentar halitose e xerostomia (ARENDORF e WALKER, 1987).

Muitos usuários de próteses removíveis desconhecem que têm EP, o que pode levar a um risco potencial de complicações em longo prazo, principalmente se esta patologia estiver associada a um quadro de debilidade imunológica (COCO et al., 2008).

A etiologia da EP mostra-se extremamente variável, podendo estar associada à alergia ao monômero residual, ao acúmulo de placa microbiana, ao trauma causado pela prótese total, à hipossalivação e à contaminação por $C$. albicans (ALLEGRA e GENNARI, 2000). Entre esses fatores, a maioria dos estudos afirma que a $C$. albicans representa o principal agente etiológico para essa patologia (ARENDORF e WALKER, 1987). 


\subsection{Tratamento medicamentoso da EP}

O tratamento direcionado à EP inclui terapia antifúngica tópica, cuidados com a higiene bucal e procedimentos de higiene e desinfecção das próteses removíveis. Geralmente, este tratamento não é fácil e recidivas ocorrem após a interrupção do uso da medicação. Logo, se tornam um desafio na prática clínica, face à sua frequência (BARBEAU et al., 2003).

\subsubsection{Antifúngicos alopáticos}

A forma tradicional de tratamento da EP consiste na prescrição de antifúngicos alopáticos de uso tópico. Entre estas drogas, destacam-se dois grandes grupos: os derivados poliênicos e azólicos (CAMPAGNOLI et al., 2004).

Fazendo parte dos derivados poliênicos, podemos destacar a nistatina e anfoterecina-B. Já os derivados azólicos podem ser divididos em dois grupos: os imidazóis e os triazóis (CAMPAGNOLI et al., 2004).

Estas drogas possuem basicamente o mesmo mecanismo de ação, inibindo a síntese de ergosterol em fungos patogênicos, aumentando a permeabilidade da membrana citoplasmática e, consequentemente, a perda de constituintes intracelulares (CAMPAGNOLI et al., 2004).

\subsubsection{Nistatina}

A nistatina é um antifúngico extraído de culturas de Streptomyces, que foi descoberta em 1950 por Hazen e Brown. (TAVARES, 2001). Este fármaco tem sido empregado na terapêutica antifúngica por mais de 50 anos, porém seu uso recente está associado ao aumento do número de casos de candidoses em pacientes com neoplasias, AIDS e outras alterações sistêmicas (GROESCHKE et al., 2006).

A nistatina é estruturalmente semelhante à anfotericina $B$, outro antifúngico polieno, e ambos possuem o mesmo mecanismo de ação. É efetiva contra a maioria das inflamações causadas pelas espécies de Candida spp., porém na prática médica é empregada apenas na profilaxia e tratamento de candidoses superficiais de pele e mucosas (TAVARES, 2001). 
A ação antifúngica da nistatina ocorre através da sua interação com ergosterol, esterol presente na membrana plasmática das células fúngicas, o que provoca uma desorganização funcional, devido à formação de canais transmembranares. Por esses canais ocorre a saída de água e íons essenciais para a sobrevida celular, como potássio, amônio, magnésio, fosfato, além da perda de açúcares, ésteres de fosfato e nucleotídeos. Essas alterações levam à perda da permeabilidade seletiva das células fúngicas, que culmina em danos celulares, e posteriormente, na morte celular (TAVARES, 2001).

A nistatina também se liga, mais fracamente, ao colesterol, outro tipo de esterol, presente na membrana plasmática das células de mamíferos. Essa ligação pode provocar efeitos adversos e tóxicos nessas células. Por essa razão, a nistatina é muito tóxica por via intramuscular e intravenosa, sendo capaz de causar hemólise, necrose e abscessos frios nos locais da injeção, devido à sua ligação imediata com as membranas plasmáticas das hemácias, causando sua destruição (TAVARES, 2001).

Os efeitos adversos da nistatina, como reações alérgicas, quando usada na forma tópica intraoral são incomuns, no entanto, podem ocorrer náuseas relacionadas ao sabor extremamente desagradável desta droga. Além disso, episódios de vômitos e diarréias podem limitar o uso pelo paciente, diminuindo a adesão do mesmo ao tratamento (NEVILLE, 2004).

Com o intuito de avaliar o efeito da nistatina no tratamento da EP, Bergendal e Isacsson (BERGENDAL e ISACSSON, 1980), recrutaram 48 pacientes com esta patologia, sendo examinados em três ocasiões distintas, a primeira no início do experimento, a segunda 14 dias após o inicio do tratamento e no $28^{\circ}$ dia após a suspensão do tratamento. Os pacientes foram instruídos para fazer uso de nistatina três vezes ao dia durante os experimentos. Os resultados apresentados demonstraram a redução dos aspectos clínicos de inflamação após os 14 dias de tratamento, porém no $28^{\circ}$ dia notou-se a recorrência dos sinais de inflamação nos mesmos níveis dos encontrados anteriormente ao tratamento.

Blomgren et al. (BLOMGREN, BERGGREN e JONTELL, 1998) compararam a eficácia clínica no tratamento da EP com nistatina e fluconazol em 60 pacientes acometidos por esta patologia. Exames clínicos foram realizados aos 7 e 21 dias após o exame inicial, e mensalmente nos 6 meses seguintes. Os autores concluíram 
que não houve diferença nos resultados dos tratamentos com os dois fármacos. A recorrência dos aspectos clínicos ocorreu em ambos os grupos.

Fatores como colaboração do paciente, aplicação intermitente do medicamento, ação de diluição da saliva e ação mecânica da musculatura podem comprometer a eficácia tópica de uma determinada droga, como antifúngicos, no meio bucal, através da redução da sua disponibilidade e da manutenção de concentrações abaixo do nível terapêutico preconizado. Assim, Egusa et al. (EGUSA et al., 2000) realizaram a exposição de isolados de Candida spp. à concentrações subterapêuticas de nistatina e anfotericina $B$ (antifúngicos poliênicos), durante 30 min, com o intuito de verificar o efeito na adesão à superfície de resina acrílica, a qual representa o evento inicial na evolução da EP. Os resultados demonstraram que a exposição à concentração menor de poliênicos foi capaz de diminuir a adesão inicial dos micro-organismos.

\subsubsection{Produtos naturais}

Apesar dos avanços no desenvolvimento de novos antifúngicos nas últimas três décadas, uma adaptação genética tem sido observada por parte dos microorganismos fúngicos em criar resistência a essas drogas. Como resultado, os tratamentos contra micoses humanas se tornam nem sempre efetivos, havendo com frequência recorrência do quadro clínico. Além disso, os antifúngios convencionais apresentam significativa toxicidade, a qual deve ser levada em consideração na prática clínica (PATTON, BONITO e SHUGARS, 2001).

Tendo em vista estas dificuldades que interferem no tratamento da EP com agentes antifúngicos, é de suma importância o estudo de outras substâncias medicamentosas eficazes para EP e com menor efeito colateral ao paciente (PAIVA et al., 2008). Deste modo, nas últimas décadas, observa-se um aumento do uso de produtos naturais para a prevenção de doenças bucais. Relatos na literatura têm demonstrado que estes produtos apresentam atividade antimicrobiana sobre os patógenos bucais (KOO et al., 2000a; SAMET et al., 2007; PAIVA et al., 2008), porém a literatura sobre a ação antimicótica de biofarmacos ainda é escassa. 


\subsubsection{Plantas medicinais}

As plantas têm uma capacidade quase ilimitada para sintetizar várias substâncias aromáticas provenientes do seu metabolismo primário e secundário (COWAN, 1999). Os carboidratos, as proteínas, os ácidos graxos e os ácidos nucléicos são substâncias essenciais à sobrevivência e ao desenvolvimento do vegetal e são produtos do seu metabolismo primário (VERPOORTE e MEMELINK, 2002). Além desses metabólitos, as plantas produzem uma variedade de metabólitos secundários. Esses compostos, não necessariamente essenciais ao organismo produtor, exercem um papel importante na sobrevivência da planta em seu ecossistema. Em muitos casos, estas substâncias servem como mecanismos de defesa da planta contra a predação por micro-organismos, insetos e herbívoros. Ainda, algumas substâncias, como os terpenóides, conferem odores aos vegetais e outras, como as quinonas e taninos, são responsáveis pela pigmentação (VERPOORTE, VAN DER HEIJDEN e MEMELINK, 2000)

Assim como os metabólitos primários, praticamente todos os metabólitos secundários são formados do metabolismo da glicose. Esta é convertida em moléculas de ácido pirúvico que podem seguir duas vias metabólicas distintas. $\mathrm{Na}$ primeira, moléculas de piruvato entram na via do ácido chiquímico para formar todos os metabólitos secundários aromáticos (alcaloides indólicos, quinolínicos, isoquinolínicos, ligninas e lignanas, cumarinas e taninos hidrossolúveis). Na segunda, o piruvato é oxidado até a formação de moléculas de acetil-coenzima $A$ (acetil-coA). Estas podem seguir três vias diferentes: via do ciclo do ácido cítrico, via do mevalonato e via da condensação do acetato. Os produtos destas três vias são os alcalóides pirrolidínicos, tropânicos, pirrolizidínicos, piperidínicos e quinolizidínicos, os terpenóides, os esteróis e as acetogeninas. A combinação de uma unidade do ácido chiquímico e uma ou mais unidades do acetato ou derivados destes, poderá resultar na produção de antraquinonas, de flavonóides e dos taninos condensados (OLIVEIRA et al., 2003).

Estes metabólitos secundários encontram-se presentes nas plantas em baixas concentrações, porém com uma variedade química muito grande. A literatura reporta que já foram isolados pelo menos doze mil diferentes compostos, um número inferior a $10 \%$ do estimado. São estes os compostos bioativos produzidos pelos vegetais e os responsáveis pelas propriedades terapêuticas encontrada nas 
plantas medicinais(COWAN, 1999). Sendo assim, o efeito farmacológico é resultado da ação de uma ou mais substâncias presentes na composição química da planta, denominada de principio ativo.

Entre todos esses compostos, certamente o que mais vem chamando atenção dos pesquisadores são os flavonóides (HAVSTEEN, 2002). Os flavonóides compõem uma ampla classe de substâncias de origem natural, cuja síntese não ocorre na espécie humana. Consequentemente, muitas dessas propriedades atuam de forma benéfica para a saúde humana. Atualmente, já foram identificadas mais de quatro mil substâncias pertencentes ao grupo dos flavonóides. Podem representar uma barreira química de defesa contra micro-organismos (bactérias, fungos e vírus), insetos e outros animais herbívoros (MARCUCCI, 1996).

Cerca de 4.000 substâncias diferentes já foram listadas como flavonóides, entre elas flavonas, flavonois, dihidroflavonóides, antocianidinas, isoflavonóides, catequinas e seus precursores metabólicos conhecidos como chalconas. A presença e a concentração destes compostos são utilizadas como índice de qualificação de amostras de própolis (LU, WU e YUAN, 2004). A ingestão de flavonóides interfere em diversos processos fisiológicos, auxiliando na absorção e na ação de vitaminas, atuando nos processos de cicatrização como antioxidantes, além de apresentarem atividade antimicrobiana (WILLIAMS, SPENCER e RICE-EVANS, 2004).

\subsection{Uncaria tomentosa e Punica granatum}

$\mathrm{Na}$ área da botânica, atualmente, uma das plantas mais estudadas é a Uncaria tomentosa, também conhecida como "unha de gato". Esta planta é uma vinha de madeira larga e seu nome é proveniente dos espinhos em forma de gancho que crescem ao longo da vinha e envolvem a planta (HEITZMAN et al., 2005; DE SOUZA e CIMERMAN, 2010).

Embora o gênero Uncaria se apresente amplamente distribuído em regiões tropicais da Ásia, África e America do Sul, a espécie U. tomentosa se encontra distribuída unicamente nas Américas Central e do Sul, sobretudo, na Amazônia Peruana. Também, dentro deste gênero, a $U$. tomentosa apresenta maior número de princípios ativos identificados, aproximadamente cinquenta. Entre estes princípios, destacam-se os alcalóides oxindólicos e indólicos, o ácido quinóvico, os esteróides, os flavonóides, os triterpenos e as catequinas, pois estes conferem propriedades 
anti-inflamatórias, antimicrobianas, imunoestimulantes, antineoplásicas, antioxidantes e citoprotetoras a esta planta (HEITZMAN et al., 2005; CCAHUANAVASQUEZ et al., 2007; PAIVA et al., 2008).

Em face destas considerações, pesquisas laboratoriais e clínicas têm sido realizadas visando melhorar o conhecimento sobre as propriedades químicas e farmacológicas desta planta e, consequentemente, aprimorar a sua utilização na área da saúde.

Sheng et al. (SHENG, BRYNGELSSON e PERO, 2000) avaliaram o efeito de um extrato solúvel em água de $U$. tomentosa (C-MED-100TM) na reparação de DNA em ratos e no sistema imunológico de ratos e de voluntários humanos. Para isto, foi administrado diariamente um extrato solúvel em água de $U$. tomentosa (CMED-100 ${ }^{\mathrm{TM}}$ ) em ratos, nas doses de 0,5, 10, 20, 40 e $80 \mathrm{mg} / \mathrm{kg}$, durante 8 semanas consecutivas. Nesses animais, foi observado um significativo aumento no número de leucócitos e de linfócitos, a partir das doses de 40mg/kg, em comparação ao grupo controle. Ademais, foi observado efeito reparador no DNA dos ratos expostos à intensa radiação por $3 \mathrm{~h}$. Também, não houve sinais de toxicidade aguda ou crônica e de alterações patológicas em associação com 100-C-MEDTM. Em 4 voluntários humanos sadios, o C-MED-100 ${ }^{\mathrm{TM}}$ foi administrado diariamente a $5 \mathrm{mg} / \mathrm{kg}$, durante 6 semanas consecutivas. Nenhuma toxicidade foi observada e, novamente, o número de leucócitos foi significativamente elevado após a administração da droga. A partir desses resultados, os autores afirmaram que os efeitos simultâneos de melhorias imunológicas e de reparação do DNA observados neste estudo, associado aos efeitos antioxidantes relatadas em outras pesquisas, sugerem que os produtos naturais, como o extrato de $U$. tomentosa, devem ser estudados mais profundamente, a fim de utilizá-las na quimioprevenção do DNA e em doenças autoimunes e inflamatórias.

Aguilar et al. (AGUILAR et al., 2002) avaliaram as diferenças entre os extratos aquoso e hidroalcoólico de $U$. tomentosa na atividade anti-inflamatória. Os testes in vitro mostraram que ambos os extratos apresentam capacidade inibitória de enzimas COX-1 e COX-2. Quando comparados entre si, o extrato hidroalcoólico foi mais efetivo na inibição da COX-2 enquanto o extrato aquoso mostrou maior inibição da COX-1. Conclui-se que os extratos testados de $U$. tomentosa apresentam atividade anti-inflamatória. 
Mur et al. (MUR et al., 2002) avaliaram a eficácia clínica do uso do extrato de $U$. tomentosa em pacientes com artrite reumatóide ativa. Durante a primeira fase deste estudo duplo cego (24 semanas), os pacientes que receberam $U$. tomentosa manifestaram uma redução significativa no número de articulações com sintomatologia dolorosa $(53,2 \%)$ em comparação com o grupo placebo. Durante a segunda fase do estudo (28 semanas) ambos os grupos receberam $U$. tomentosa, sendo que os pacientes que durante a primeira fase receberam placebo manifestaram uma redução significativa da sintomatologia dolorosa depois da segunda fase.

Ccahuana-Vasquez et al. (CCAHUANA-VASQUEZ et al., 2007) avaliaram a atividade antimicrobiana de diferentes concentrações de $U$. tomentosa sobre cepas de micro-organismos isolados de cavidades bucais humanas. $U$. tomentosa micropulverizada foi testada in vitro para determinar a concentração inibitória mínima (CIM) em isolados microbianos selecionados. Cepas de Streptococcus mutans, Staphylococcus spp., C. albicans, Enterobacteriaceae e Pseudomonas aeruginosa avaliadas foram isoladas de cavidades bucais humanas. Foram preparadas as concentrações de $U$. tomentosa entre 0,25 e $5 \%$ em ágar Müeller-Hinton. $U$. tomentosa a $3 \%$ inibiu $8 \%$ de Enterobacteriaceae, $52 \%$ de $S$. mutans e $96 \%$ de Staphylococcus spp.. As concentrações testadas não apresentaram efeito inibitório sobre $P$. aeruginosa e $C$. albicans. Deste modo, concluiu-se que $U$. tomentosa micropulverizada apresenta atividade antimicrobiana sobre cepas de Enterobacteriaceae, S. mutans e Staphylococcus spp..

Reis et al. (REIS et al., 2008) avaliaram a atividade imunomodeladora e antiviral dos alcalóides da $U$. tomentosa sobre o vírus da dengue tipo 2 (DENV-2) utilizando um modelo in vitro de infecção. Monócitos humanos infectados por DENV2 foram incubados com alcalóides da $U$. tomentosa. Foi determinada a atividade antiviral, pela presença dos antígenos virais (DENV-Ag) e também foram determinados os níveis de citocinas (TNF- $\alpha$, IFN- $\alpha$, IL-6 e IL-10). Os resultados mostraram uma diminuição significativa nos níveis de DENV-Ag, TNF- $\alpha$ e IFN- $\alpha$. Os autores concluíram que os alcalóides da $U$. tomentosa são efetivos na redução da infecção de monócitos pelo DENV-2, possuindo um potencial terapêutico de aplicação clínica nos casos de dengue.

Para avaliar a ação do gel da U. tomentosa em pacientes portadores de EP, Paiva et al. (PAIVA et al., 2008) selecionaram 20 pacientes apresentando esta 
patologia. Os mesmos foram divididos em 2 grupos, sendo que o grupo teste $(U$. tomentosa/Imuno-Max), composto por 10 pacientes, utilizou o gel da $U$. tomentosa sobre as lesões na cavidade oral, 3 vezes ao dia, por um período de 14 dias. 0 grupo controle (Miconazol/Daktarin® Gel) utilizou a medicação da mesma forma prescrita para o grupo-teste. Após o período de tratamento, os pacientes retornaram para nova avaliação clínica e laboratorial. A $U$. tomentosa mostrou ser um fitofármaco promissor na odontologia, apresentando vantagem sobre o miconazol de não ter provocado reações adversas nos pacientes, uma vez que, $40 \%$ dos pacientes do grupo controle apresentaram reações indesejáveis.

Souza Júnior et al. (SOUZA JÙNIOR et al., 2011) avaliaram in vitro a ação antifúngica do extrato hidroalcóolico da $U$. tomentosa sobre cepas padrão de $C$. albicans, C. guilliermondii, Candida krusei e C. tropicalis, responsáveis por afecções bucais conhecidas por candidoses. O material botânico utilizado para os testes foram 0 extrato micropulverizado do caule da $U$. tomentosa. $A$ atividade antimicrobiana e determinação da CIM do extrato da $U$. tomentosa foi determinada através da técnica de ágar-difusão em placas de Petri. Os mesmos procedimentos foram realizados com a clorexidina em concentração $0,12 \%$, um antisséptico oral utilizado como controle positivo nos experimentos. Os resultados demonstraram que todas as espécies avaliadas apresentaram-se sensíveis ao extrato da $U$. tomentosa, atuando de forma semelhante à ação da clorexidina (controle positivo). As cepas apresentaram halos de inibição de crescimento até a diluição de 1:16 do extrato. $C$. albicans foi o micro-organismo que apresentou maior sensibilidade ao extrato da $U$. tomentosa, seguido de C. guilliermondii, C. krusei e C. tropicalis.

Além da $U$. tomentosa, atualmente, muitos trabalhos científicos têm sido realizados a fim de se estudar as propriedades medicinais da romãzeira (Punica granatum Linné) (MACHADO et al., 2003; VASCONCELOS et al., 2003; VASCONCELOS et al., 2006). Esta planta apresenta um arbusto lenhoso e ramificado, sendo nativa da região que abrange desde o Irã até o Himalaia, a noroeste da Índia. Os preparos obtidos da romãzeira (flor, fruto e casca da árvore) são popularmente usados para tratar vários problemas de saúde (LANGLEY, 2000). O extrato da $P$. granatum Linné é rico em dois tipos de compostos polifenólicos: as antocianinas, que dão a cor vermelha às frutas e ao suco, e os taninos hidrolisáveis (JURENKA, 2008). 
A literatura científica também aponta a $P$. granatum Linné como uma planta com grande potencialidade para prevenir e combater várias patologias. Neste contexto, um dos primeiros trabalhos exibindo os benefícios dos compostos fenólicos da romã foi descrito por Schubert, Lanski e Neeman (SCHUBERT, LANSKY e NEEMAN, 1999). O trabalho mostrou que os flavonóides extraídos do suco fermentado e do óleo das sementes deste fitofármaco induziram inibição da atividade das enzimas oxidantes cicloxigenase e lipoxigenases, importantes no desenvolvimento do processo inflamatório. Seguidamente, trabalhos mostraram a contribuição benéfica do suco da romã na atenuação de fatores aterogênicos (AVIRAM et al., 2000; AVIRAM e DORNFELD, 2001). Também, extrato feito com o pós da casca da fruta atuou na modulação das respostas anti-inflamatórias (GRACIOUS ROSS, SELVASUBRAMANIAN e JAYASUNDAR, 2001).

A atividade antimicrobiana é outra propriedade da $P$. granatum Linné que vem sendo amplamente estudada. Os resultados de vários estudos, incluindo alguns relativos à inibição da adesão (VASCONCELOS et al., 2006), sugerem que bactérias orais e C. albicans são sensíveis a esse extrato. $O$ mecanismo específico da ação dos princípios biativos desta planta sobre os micro-organimos ainda não está totalmente elucidado. Porém, acredita-se que os taninos, principais polifenóis do extrato da $P$. granatum Linné, atuam no metabolismo celular, através das paredes celulares. Estes compostos se ligam à parede celular, atravessam essa estrutura e interferem na produção de proteínas e enzimas microbianas. Além disso, os taninos atuam perturbando a co-agregação entre os micro-organismos na parede celular (VASCONCELOS et al., 2003). Corroborando com isso, Djipa et al. (DJIPA, DELMEE e QUETIN-LECLERCQ, 2000) relataram que a atividade antimicrobiana está relacionada diretamente com a alta quantidade de taninos presentes no extrato da $P$. granatum Linné, já que a eliminação destes suprimiu esta propriedade.

Vasconcelos et al. (VASCONCELOS et al., 2003) avaliaram a utilização de um gel contendo o extrato de $P$. granatum Linné como um agente antifúngico contra a EP. Foram selecionados sessenta pacientes com EP confirmada através de exame clínico e micológico. Os pacientes foram distribuídos aleatoriamente em dois grupos de 30 pessoas, de acordo com a medicação prescrita: grupo A utilizou miconazol (Daktarin® gel) e grupo B utilizou um gel de $P$. granatum Linné. Ambos os grupos utilizaram os medicamentos três vezes por dia durante 14 dias. Após $48 \mathrm{~h}$ da suspensão dos tratamentos, os pacientes foram reexaminados e um segundo grupo 
de amostras foi coletado para exames micológicos. Os medicamentos foram avaliados pela sua resposta clínica e negatividade para Candida. Os resultados clínicos demonstraram uma resposta satisfatória em 27 e 21 pacientes dos grupos A e $B$, respectivamente. Negatividade para leveduras foi observada em 25 pacientes do grupo A e 23 do grupo B. Assim, foi possível concluir que o extrato de $P$. granatum Linné pode ser utilizado como um agente antifúngico tópico no tratamento EP.

Braga et al. (BRAGA et al., 2005) avaliaram o efeito do extrato de $P$. granatum Linné sobre o crescimento de $S$. aureus e sobre a subseqüente produção de enterotoxinas. A susceptibilidade bacteriana foi determinada pelo método de tubo-diluição e a produção de enterotoxinas foi avaliada usando placas de membrana sobre ágar. Em concentrações baixas $(0,01 \% \mathrm{v} / \mathrm{v})$, o extrato inibiu 0 crescimento bacteriano, enquanto que em uma concentração mais elevada ( $1 \% \mathrm{v} / \mathrm{v})$ este extrato eliminou o crescimento bacteriano. Além disso, foi observado que na concentração de $0,05 \%$ (v/v) o extrato de $P$. granatum Linné inibiu a produção de enterotoxina estafilocócica $A$. Com base nos resultados, os autores puderam afirmar que estes extratos podem ser utilizados como potenciais agentes terapêuticos antibacterianos, com a capacidade adicional de inibir a produção de enterotoxinas.

Vasconcelos et al. (VASCONCELOS et al., 2006) se propuseram a avaliar o efeito antimicrobiano do gel de $P$. granatum Linné e do miconazol (Daktarin® gel oral) na adesão ao vidro de 3 cepas padrão de Streptococos (mutans, sangui, e mitis), do S. mutans isoladas clinicamente (IC) e da C. albicans com e sem associações. Este efeito foi analisado por meio de soluções diluídas dos géis em concentrações crescentes que variaram de 1:1 a 1:1024. As concentrações mínimas inibitórias do gel de $P$. granatum Linné na adesão contra os micro-organismos testados foram: 1:16 para S. mutans (ATCC), S. mutans (IC) and S. sanguis; 1:128 para $S$. mitis and 1:64 para $C$. albicans. As concentrações mínimas inibitórias do gel de miconazol na adesão contra os mesmos micro-organismos foram: 1:512, 1:64, 1:4, 1:128 e 1:16, respectivamente. Nos experimentos com 3 ou 4 micro-organismos associados, o gel de $P$. granatum Linné apresentou maior eficiência em inibir a adesão microbiana do que o miconazol. Os resultados deste estudo sugerem que o fitofámaco testado pode ser usado no controle da adesão de diferentes microorganismos na cavidade bucal. 
A atividade antibiótica do extrato hidroalcoólico de $P$. granatum Linné foi avaliada por Silva et al. (SILVA et al., 2008) pelo método de difusão em ágar em 38 cepas de $S$. aureus, sendo 22 resistentes à penicilina, isoladas de vacas aparentemente saudáveis, nos municípios da região semi-árida do Estado da Paraíba, Brasil, para determinar a CIM. O extrato de $P$. granatum Linné apresentou ação antimicrobiana sobre todas as cepas testadas, formando zonas de inibição variando de 10 a $36 \mathrm{~mm}$ de diâmetro. Os resultados deste estudo confirmaram a eficácia do extrato de $P$. granatum Linné como agente antibacteriano sobre $S$. aureus.

No ano seguinte, Al-Zoreky (AL-ZOREKY, 2009) realizou uma pesquisa, com o intuito de identificar atividade antimicrobiana de vários extratos de frutas de romã contra patógenos de origem alimentar. Por meio de ensaios in vitro (difusão em ágar) e in situ (em alimentos), foi possível verificar que o extrato metanólico de cascas de romã a $80 \%$ foi um potente inibidor contra Listeria monocytogenes, $S$. aureus, Escherichia coli e Yersinia enterocolitica. A CIM do extrato metanólico de cascas de romã a $80 \%$ de contra Salmonella enteritidis foi a mais elevada $(4 \mathrm{mg} / \mathrm{ml})$. Também, esse extrato proporcionou uma redução significativa de $L$. monocytogenes em alimentos (peixe) durante o armazenamento a $4^{\mathrm{C}} \mathrm{C}$. As análises fitoquímicas revelaram a presença de inibidores ativos contra micro-organismos em cascas da romã, sobretudo, compostos fenólicos e flavonóides.

Através de um estudo clínico e laboratorial, Schreiner et al. (SCHREINER et al., 2009) avaliaram a ação antimicrobiana do chá de romã na inibição da adesão de micro-organismos oriundos da saliva sobre ligaduras ortodônticas elásticas. Para isto, 30 ligaduras foram submersas em saliva e incubadas a $37^{\circ} \mathrm{C}$ por $1 \mathrm{~h}$. A seguir, a amostra foi dividida em 3 grupos: 10 ligaduras foram submersas no chá da romã por $5 \mathrm{~min}, 10 \mathrm{em}$ clorexidina (controle positivo) e 10 não receberam nenhum tratamento (controle negativo). Na sequência, alíquotas de cada grupo foram semeadas em ágar BHI. Após incubação por $48 \mathrm{~h}$, foi verificado o número de UFC/mL de micro-organismos recuperados de cada ligadura. Com o uso do chá de romã, a média de UFC/mL recuperada significativamente inferior ao controle negativo. Entretanto, a ação da clorexidina foi significativamente superior à do chá de romã. Os resultados sugerem a possível utilização do chá de folhas da romã como um meio alternativo de controle químico do biofilme dental em usuários de aparelhos ortodônticos. 
Choi et al. (CHOl et al., 2011) avaliaram a atividade antimicrobiana in vivo do extrato etanólico de $P$. granatum contra de Salmonella em camundongos. Os camundongos foram inicialmente infectados com Salmonella typhimurium, e depois tratados com extrato etanólico de $P$. granatum. O extrato foi aplicado para ter efeitos significativos sobre a mortalidade e o número de $S$. typhimurium viáveis recuperados de fezes. Enquanto os sinais clínicos e as lesões histológicas foram raramente observados nos camundongos tratados, os que não foram tratados apresentaram sinais de letargia e danos histológicos no fígado e no baço. Além disso, foi observada uma redução significativa no número de $S$. typhimurium viáveis, recuperadas de fezes de camundongos infectados, após o tratamento com o extrato etanólico de $P$. granatum, em relação aos camundongos infectados e não tratados. Com base nos resultados, os autores afirmaram que o extrato etanólico da $P$. granatum apresenta potencial terapêutico para casos de salmoneloses.

\subsection{Propólis}

Os produtos que contêm própolis e que apresentem indicações terapêuticas podem ser registrados como medicamentos específicos segundo a Resolução-RDC no 132, de 29 de maio de 2003, D.O.U. de 02/10/2003, sendo classificados como opoterápicos. Estas preparações são aquelas que são obtidas a partir de glândulas, outros órgãos, tecidos e secreções animais (BRASIL, 2003).

A própolis é o nome genérico de uma resina oriunda de diversas partes de plantas (como broto e botões florais), a qual é coletada pelas abelhas da espécie Apis mellifera. Posteriormente, modificações são realizadas nesta resina pelas abelhas, por meio da adição de secreções próprias. O nome "própolis" é derivado do grego pro, em defesa de, e polis, a cidade, e quer dizer: "em defesa da cidade ou da colméia"(MARCUCCI, 1996).

Polifenóis foram identificados como os principais constituintes orgânicos da própolis, representado principalmente por flavonóides e acompanhado por ácidos fenólicos, ésteres, aldeídos fenólicos e cetonas (SIMÕES, DE ARAÚJO e DE ARAÚJO, 2008). Estudos têm relatado notável efeito antibacteriano, antifúngico, anti-inflamatório, antioxidante e propriedades imunomoduladoras, sobretudo, aos flavonóides presentes na própolis (MARCUCCI, 1996; KOO et al., 2000a; SFORCIN, ORSI e BANKOVA, 2005). 
Em relação à atividade antimicrobiana, esta pode ocorrer através de um efeito sinergístico entre flavonóides, hidroxiácidos e sesquiterpenos sobre microorganismos, inibindo a síntese da RNA-polimerase (MARCUCCI, 1996; BOSIO et al., 2000). Além disso, achados ultraestruturais vistos em microscopia digital demonstram que a própolis pode romper a parede celular, por meio de um aumento em volume da célula (SANTOS et al., 2008; CASAROTO e LARA, 2010). Além disso, esta substância pode atuar indiretamente contra os patógenos, através da estimulação de macrófagos e de anticorpos no sistema imunológico ação imunomoduladora (SFORCIN, ORSI e BANKOVA, 2005).

Como citado anteriormente, a atividade antimicrobiana da própolis está diretamente relacionada à sua composição química. Porém, os compostos químicos presentes na própolis variam de acordo com a espécie de abelha, a área geográfica de origem e dos métodos de extração e controle de qualidade do produtor e até da época do ano (SFORCIN et al., 2000; SFORCIN, ORSI e BANKOVA, 2005). Logo, todos estes fatores podem alterar a atividade antimicrobiana da própolis (LU, CHEN e CHOU, 2005; SIMÕES, DE ARAÚJO e DE ARAÚJO, 2008).

A partir deste conhecimento, a própolis é alvo constante de estudos in vitro e in vivo, em diversos países, com o objetivo de se obter o máximo de informações, na tentativa de fazer com que a Organização Mundial de Saúde (OMS), bem como os Ministérios de Saúde dos diversos países aprovem a própolis como medicamento.

Grange e Davey (GRANGE e DAVEY, 1990) observaram que os extratos etanólicos de própolis inibiram completamente o crescimento de $S$. aureus, $S$. epidermidis, Enterococcus spp., Corynebacterium spp., Branhamella catarrhalis e Bacillus cereus, inibiram parcialmente o crescimento da Pseudomonas aeruginosa e Escherichia coli, mas não tiveram efeito sobre Klebsiella pneumoniae, demonstrando inibição preferencial sobre cocos em detrimento de bacilos Gram positivos.

A atividade antimicrobiana in vitro da própolis foi verificada contra várias linhagens de bactérias Gram positivas (Bacillus brevis, Bacillus cereus, Bacillus megatherium, Bacillus polymyxa, Bacillus pumilus, Bacillus sphaericus, Bacillus subtilis, Cellulomas funi, Nocardia globerula, Leuconostoe mesenteroides, Micrococcus lysodeikticus, Sarcina lutea, Staphylococcus aureus e Streptococcus faecalis) e Gram negativas (Aerobacter aerogenes, Alcaligenes sp., Bordetella bronchiseptica, E. coli, Proteus vulgaris, Pseudomonas aeruginosa e Serratia marcescens). Verificou-se que de 39 linhagens de bactérias testadas, o crescimento 
de 25 delas foi inibido na presença de concentrações de própolis menores que 100 $\mu \mathrm{g} / \mathrm{mL}$ (MARCUCCI, 1996).

Koo et al. (KOO et al., 2000a) avaliaram a atividade antimicrobiana in vitro, inibição da aderência do micro-organismo $S$. mutans e inibição da formação de glucanos insolúveis em água, utilizando a espécie vegetal Arnica montana e extratos etanólicos de própolis do estado de Minas Gerais, Brasil. Os extratos de própolis inibiram significativamente todos os micro-organismos testados, e o extrato de própolis do tipo III apresentou o maior espectro de ação antimicrobiana. Entretanto, os extratos de $A$. montana não apresentou uma atividade antimicrobiana significativa. Os autores constataram que o extrato de própolis mostrou atividade antimicrobiana, inibição da aderência celular e inibição da formação de glucanos insolúveis em água, enquanto que o extrato de $A$. montana foi pouco ativo nestas mesmas três condições.

Koo et al. (KOO et al., 2000b) avaliaram o efeito de uma nova variedade de própolis do estado da Bahia, Brasil, sobre o crescimento do micro-organismo $S$. mutans, aderência celular e síntese de glucanos insolúveis em água. Neste trabalho os autores também testaram as própolis do sudeste (MG) e sul (RS) do Brasil. O perfil da nova variedade de própolis foi totalmente diferente das própolis do Sudeste e Sul, não sendo detectado nenhum flavonóide ou ácido cumárico. Todos os extratos etanólicos de própolis demonstraram atividade biológica contra o microorganismo S. mutans, entretanto o extrato etanólico de própolis da Bahia mostrou $80 \%$ de inibição da aderência celular e baixa síntese de glucanos insolúveis. Os autores concluíram que a nova variedade de própolis foi excepcionalmente efetiva em todos os parâmetros testados in vitro contra o micro-organismo S. mutans, e que os efeitos biológicos não estão relacionados somente com flavonóides e derivados do ácido cinâmico.

A comprovada eficácia antimicrobiana da própolis, aliada à sua atividade anti-inflamatória, estimularam o desenvolvimento de estudos em relação à sua eficácia no tratamento tópico da EP.

Neste sentido, Ota et al. (OTA et al., 2001) investigaram, de forma laboratorial e clínica, a atividade antifúngica de uma solução alcoólica de própolis. A avaliação in vitro foi realizada através da determinação da CIM desse extrato sobre cepas de C. albicans, C. tropicalis, C. krusei e C. guilliermondii. Para a análise in vivo foram escolhidos 12 pacientes portadores de prótese total com uma 
concentração de Candida na saliva acima de mais de $400 \mathrm{UFC} / \mathrm{ml}$. Estes pacientes utilizaram uma solução hidroalcoólica de própolis a $6 \%$ como um enxaguatório bucal duas vezes ao dia, de manhã e à noite antes de dormir, por um período de 2 semanas. Antes do início tratamento, no fim da primeira semana e no fim da segunda semana, foi realizada a coleta de cada paciente para avaliar concentração de $C$. albicans na saliva. Como resultados, foram observados que todas as cepas de Candida mostraram ser sensíveis à solução alcoólica de própolis, sendo as cepas de C. albicans mais sensíveis. Por outro lado, a espécie mais resistente testada foi a $C$. guilliermondii. A parte clínica deste estudo revelou que todos os pacientes tratados com a solução hidroalcoólica de própolis a $6 \%$ apresentaram uma significante redução do número de levedura Candida na saliva.

Santos et al.(SANTOS et al., 2005) selecionaram dezoito pacientes com esta patologia, onde doze foram tratados com extrato alcoólico de própolis a $20 \%$, quatro vezes ao dia, por sete dias e seis pacientes, como grupo controle positivo, foram tratados com nistatina (Micostatin $100.000 \mathrm{Ul} / \mathrm{mL}$ ). Como métodos de avaliação dos tratamentos, foram feitas análises da mucosa do paciente através da técnica do PAS (Periodic Acid-Schiff) e análise bioquímica (Candifast, International Microbio, France) antes e depois de cada tratamento. Através dos resultados obtidos, foi observado que todos os pacientes tratados com o extrato alcoólico de propólis a $20 \%$ demonstraram regressão da infecção fúngica similar ao que aconteceu com aqueles tratados com nistatina. Portanto, foi demonstrado que o extrato alcoólico de própolis a $20 \%$ utilizado é efetivo no tratamento da EP.

Estes mesmos autores (SANTOS et al., 2008) realizaram uma avaliação clínica a respeito de uma nova formulação de gel de própolis brasileiro com 30 pacientes diagnosticados com EP. No baseline foram realizadas avaliações clínicas por um clínico único e foram dadas instruções de higiene de prótese a todos os pacientes. Quinze pacientes receberam Daktarin® (Miconazol gel) e quinze receberam gel de própolis brasileiro. A todos os pacientes foram recomendados para aplicar o produto quatro vezes por dia durante uma semana. A avaliação clínica foi repetida pelo mesmo clínico após 7 dias de tratamento. Como resultado, foi observado que todos os pacientes tratados com gel de própolis brasileiro e Daktarin ${ }^{\circledR}$ tiveram completa remissão clínica do edema e do eritema palatal. Os autores concluíram que esta nova formulação de gel de própolis brasileiro obteve 
eficácia comparável ao Daktarin $\circledast$ e pode ser uma medicação tópica alternativa no tratamento da EP.

\subsection{Análise dos efeitos de substâncias antimicrobianas sobre biofilmes}

$\mathrm{Na}$ literatura, observa-se uma vasta descrição da atividade antimicrobiana de diferentes produtos naturais. Em linhas gerais, estes estudos têm focado na ação dessas substâncias sobre células planctônicas bacterianas e fúngicas, com menor atenção aos biofilmes, os quais representam uma importante forma de resistência contra agentes antimicrobianos.

No estudo dos biofilmes, tradicionalmente, a microscopia eletrônica de varredura (MEV) tem sido o método de escolha, devido à sua alta resolução. Esta técnica permite a observação da presença e da morfologia dos micro-organismos, assim como da formação de biofilme e das diferentes associações microbianas na superfície de materiais poliméricos. Além disso, possibilita a análise minuciosa dos efeitos causados pelas soluções desinfetantes sobre micro-organismos em biofilmes, como a remoção destes da superfície do material e alterações na sua morfologia. No entanto, esta técnica requer, como pré-requisito, que o biofilme deva ser submetido aos processos de desidratação e de fixação, portanto, esta não é apropriada para o estudo de características funcionais de micro-organismos em biofilmes, como a viabilidade celular (WOOD et al., 2000).

A microscopia de fluorescência tem se revelado um método mais sensível na caracterização da viabilidade de micro-organismos, inclusive de células em biofilmes. A determinação da viabilidade por meio desta técnica ocorre através do uso de marcadores fluorescentes, denominados fluorocromos, que possibilitam a avaliação de aspectos funcionais e estruturais das células. O fluoróforo é a parte presente no fluorocromo responsável pela produção de fluorescência. A fluorescência ocorre por um fenômeno onde elétrons do fluoróforo absorvem fótons provindos de uma fonte (lâmpada ou feixe laser) e passam de um estado fundamental de energia mais baixa para um estado excitado de energia mais elevada. Nesse estado, o fluoróforo passa por uma mudança em sua conformação e pode interagir com uma série de moléculas ao seu redor. Com isso a energia deste estado excitado é dissipada em forma de fóton e o elétron retorna novamente para o 
estado de menor energia. A técnica de microscopia de fluorescência consiste justamente em captar este fóton que é emitido e através dele gerar uma imagem (ALBERTS, 2004).

Entre as técnicas de microscopia de fluorescência, a microscopia confocal de varredura a laser, associada à aplicação de fluorocromos específicos à amostra a ser analisada, proporciona a análise de biofilmes sem o preparo dos espécimes, dispensando procedimentos como a desidratação, a embebição e a fixação (ZAURA-ARITE, VAN MARLE e TEN CATE, 2001). Deste modo, a arquitetura e organização interna do biofilme são mantidas, além de outras características, como a espessura e a viabilidade celular (WOOD et al., 2000). Outra vantagem do microscópio confocal para o estudo do biofilme é sua capacidade de captar imagens em diferentes profundidades de foco, facilitando a visualização de espécimes irregulares, densos e espessos de maneira tridimensional (KUBINOVA e JANACEK, 2001).

Em relação à utilização de fluorocromos na análise da viabilidade de células fúngicas presentes em biofilmes, a literatura demonstra a frequente utilização do fluorocromo FUN-1 com esse propósito. Através deste marcador, as células fúngicas metabolicamente não ativas (não viáveis) emitem uma coloração fluorescente difusa verde-amarelada, enquanto que nas células metabolicamente ativas (viáveis), o FUN-1 é convertido em estruturas cilíndricas intravacuolares de coloração laranjaavermelhada, fazendo com que estas células emitam esta mesma coloração. Entretanto, o FUN-1 pode provocar a formação de múltiplas estruturas cilíndricas intravacuolares nas células metabolicamente ativas na forma de hifas, possibilitando a superestimação do número de células viáveis quando a densidade celular é elevada no biofilme. Logo, o FUN-1 não é ideal para a avaliação da viabilidade celular de biofilmes fúngicos (JIN et al., 2005).

$\mathrm{Na}$ busca de um fluorocromo que suprisse a limitação do FUN-1, Jin et al. (JIN et al., 2005) obtiveram êxito na determinação da viabilidade de $C$. albicans em biofilmes, através da utilização do Live/Dead® BacLight ${ }^{\top \mathrm{TM}}$ Kit (Molecular Probes, Burlington, ON, Canada), embora este seja comumente utilizado na análise de viabilidade bacteriana. Este Kit é composto de dois fluorocromos de afinidade pelos ácidos nucléicos, o SYTO-9 e o iodeto de propídeo.

Através da coloração atribuída por esses fluorocromos, é possível se determinar a viabilidade microbiana tendo como parâmetro a integridade da 
membrana citoplasmática que é imprescindível para manutenção da viabilidade celular. Quando usado sozinho, o fluorocromo SYTO-9 penetra tanto em células vivas, quanto em células mortas. Em contraste, o iodeto de propídeo penetra somente em micro-organismos mortos, com membrana comprometida. Quando utilizados simultaneamente, o iodeto de propídeo reduz o SYTO-9 no interior das células mortas. Deste modo, micro-organismos vivos, com membrana citoplasmática intacta, demonstram fluorescência verde, enquanto micro-organismos mortos, com membrana comprometida, apresentam fluorescência vermelha (JIN et al., 2005; SILVA et al., 2011).

\subsection{Alterações superficiais em resinas acrílicas causadas por nistatina e por produtos naturais}

Não obstante a comprovada eficácia antimicrobiana de antifúngicos e produtos naturais, pouco se sabe a respeito dos efeitos destas drogas sobre as propriedades superficiais de resinas acrílicas utilizadas próteses dentárias removíveis. Sempre há a preocupação a respeito de possíveis efeitos danosos na rugosidade e na microdureza desses materiais, visto que estas alterações podem tornar as resinas acrílicas mais susceptíveis ao aparecimento de ranhuras, as quais aumentam a capacidade de adesão de micro-organismos, oferecem proteção aos mesmos contra os métodos mecânicos de higiene empregados nas próteses, favorecem a instalação e o desenvolvimento de biofilmes microbianos e dificultam ainda mais o tratamento das infecções fúngicas, como a EP (RAHAL et al., 2004).

Com esse intuito, Da Silva et al. (DA SILVA et al., 2008) avaliaram o efeito do fluconazol, nistatina e gel orabase de extrato etanólico de própolis a $20 \%$ sobre a superfície de resinas acrílicas. Água deionizada e gel de própolis sem princípio ativo (própolis) foram utilizados como controles. Espécimes de resina acrílica polimerizados através de banho maria ou micro-ondas receberam acabamento e polimento e tiveram a rugosidade de superfície (RS), energia livre de superfície (ELS) e microdureza Knoop (DK) mensuradas. Os tratamentos de superfície foram obtidos pela imersão dos espécimes nos produtos avaliados durante 14 dias. Os resultados demonstraram que os grupos tratados com gel de própolis mostraram valores maiores de RS e DK, os quais foram estatisticamente diferentes dos demais 
antifúngicos. Com relação à RS e à ELS das resinas tratadas com fluconazol e nistatina, não foram encontradas diferenças entre estas. Com base no exposto, os autores afirmaram que o gel de própolis induziu modificações na superfície das resinas acrílicas, aumentando a rugosidade e microdureza.

Da Silva et al. (DA SILVA et al., 2011), através de uma ensaio laboratorial, verificaram se o poli(metil metacrilato) (PMMA) é capaz de absorver e liberar nistatina e fluconazol após a simulação de um tratamento para EP. Espécimes de resina de PMMA foram preparados através de banho maria ou por meio de microondas e, em seguida, imersos em solução contendo nistatina, fluconazol ou água deionizada (controle) durante 14 dias. Após a simulação de tratamento, os espécimes foram imersos em água destilada durante 3, 7, 10 e 14 dias. O líquido de imersão foi trocado após cada análise. Cromatografia líquida de alta performance foi utilizada para detectar a presença dos agentes antifúngicos. Para determinar se houve deposição dos agentes antifúngicos na superfície de PMMA, os espécimes foram analisados por MEV. Os resultados indicaram que não houve liberação de agentes antifúngicos dos espécimes. Deste modo, os autores puderam afirmar que a resina de PMMA não absorve ou libera agentes antifúngicos.

Ainda nesta linha, Al-Dwairi, Al-Quran e Al-Omari (AL-DWAIRI, AL-QURAN e AL-OMARI, 2012) estudaram os efeitos de antifúngicos sobre as propriedades superficiais de uma resina termopolimerizável, usada para base de próteses totais e a sua relação com a adesão in vitro de Candida albicans. Para isso, espécimes de resina foram imersos durante 14 dias em nistatina (grupo 1), em fluconazol (grupo 2), em água destilada (grupo 3) e em nenhuma substância (grupo 4). Após o período de imersão, a rugosidade superficial, o ângulo de contato, a dureza e a aderência de Candida ao material foram analisados nas amostras e comparados com 0 grupo 4 (não exposto). Os resultados mostraram que a nistatina não alterou a dureza superficial, mas aumentou a rugosidade superficial, o ângulo de contato e a aderência de Candida ao material resinoso. Por outro lado, o fluconazol não alterou a dureza e a rugosidade, mas teve um efeito significativo sobre o ângulo de contato e adesão da Candida à resina. Água destilada não provocou alterações em nenhuma das propriedades superficiais avaliadas. Os autores concluíram que a exposição da resina estudada à nistatina pode provocar mudanças na molhabilidade e na aspereza, enquanto que a exposição ao fluconazol pode afetar a energia livre de superfície e, portanto, aumentar a adesão da Candida a este material. 
Uma vez que o álcool faz parte da composição química de vários produtos naturais, como o extrato alcoólico de própolis, uma investigação a respeito do efeito dessa substância sobre as propriedades físicas resinosas é relevante. Com essa finalidade, Regis et al. (REGIS et al., 2009) utilizaram 60 espécimes circulares e 60 retangulares de resina acrílica polimerizada por micro-ondas, dividindo-as em 6 grupos, de acordo com as concentrações de etanol das soluções, nas quais as amostras foram imersas ( $0 \%$ (água), 4,5\%, 10\%, 19\%, 42\%, e 100\%). Os espécimes permaneceram imersos durante 30 dias. Após este período, as amostras foram submetidas ao teste de dureza, de rugosidade, de resistência à flexão e de alteração de cor. Os resultados revelaram que, em linhas gerais, com o aumento das concentrações de etanol das soluções, houve a diminuição da dureza e o aumento da rugosidade na superfície resinosa, a diminuição da resistência flexural e a alteração de cor. Os autores puderam concluir que o etanol provocou um efeito dissolvente e plastificante sobre o material testado, sobretudo, a partir de $42 \%$.

Apesar do crescente desenvolvimento de estudos sobre a eficácia laboratorial de biofarmacos, com constante identificação de novos princípios ativos, o conhecimento a respeito destes produtos ainda é escasso ou nem sempre tem sido transportado para a aplicação clínica. Mediante essas infomações, a realização do presente estudo visa fornecer mais referências sobre a eficácia clínica e laboratorial de produtos naturais e, assim, contribuir para a elaboração de drogas alternativas para o tratamento da EP. 



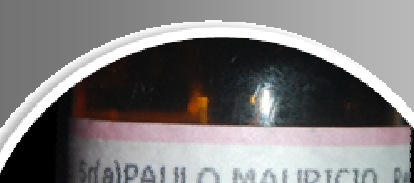

AGUA DESTILADA

D: EXTERNO
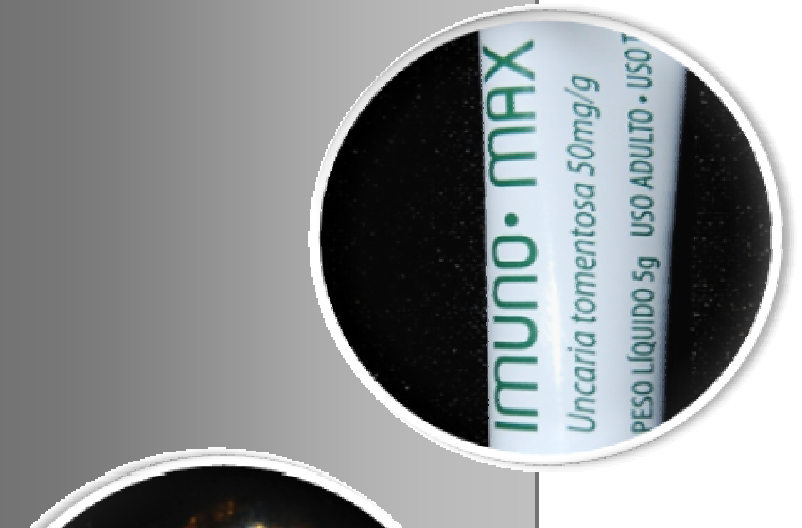

(a)PAULO MAURICIO MURA DE PROPOLIS 209

W:INTERNO

6. 10/08/11

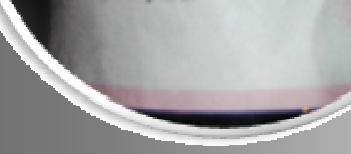

exato fluido de Punica grangts

(20. ERTERNO

p. 10,00

E

$+2$

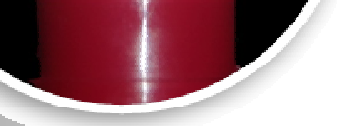

\section{MS}

2 Proposição

\section{nistatina}

100.000 UI por done de $1 \mathrm{mit}$

Suspensilo Oral

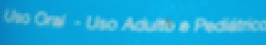

Contwido 60 mit com conth gats 



\section{PROPOSIÇÃO}

Os objetivos deste estudo foram:

- Avaliar clinicamente o efeito antifúngico dos produtos naturais no tratamento da EP;

- Avaliar in vitro o efeito antifúngico de produtos naturais sobre biofilmes de $C$. albicans em uma resina acrílica termopolimerizável através de microscopia confocal;

- $\quad$ Avaliar in vitro o efeito de sucessivas aplicações de produtos naturais na rugosidade superficial e na microdureza de uma resina acrílica termopolimerizável. 




\section{MATERIAL E MÉTODOS}

\subsection{Avaliação clínica do efeito antifúngico de produtos naturais no tratamento da EP}

\subsubsection{Comitê de Ética em Pesquisa}

Este estudo obteve aprovação pelo Comitê de Ética em Pesquisa da Faculdade de Odontologia de Bauru - FOB/USP (Anexo A). Para participar da pesquisa, todos os pacientes assinaram um termo de consentimento livre e esclarecido, o qual foi devidamente preenchido pelo pesquisador responsável (Anexo B).

\subsubsection{Anamnese e exame clínico}

Indivíduos residentes e/ou frequentadores de dois abrigos da região metropolitana de Belém-PA, entre homens e mulheres, com idade entre 50 e 81 anos que apresentaram diagnóstico clínico sugestivo para EP foram inicialmente submetidos à anamnese completa e ao exame clínico por um único examinador, de acordo com a ficha clínica aplicada utilizada neste estudo (Anexo C).

$\mathrm{Na}$ anamnese, os indivíduos foram questionados quanto a uso de medicamentos, estado geral de saúde (anterior e atual) e histórico de saúde familiar.

Em seguida, foi realizado um exame clínico detalhado das seguintes regiões: palato, mucosa jugal, língua, lábios e orofaringe de cada indivíduo. O exame criterioso da região palatina permitiu a classificação da EP de cada indivíduo em três tipos clínicos, de acordo com Newton (BARBEAU et al., 2003).

Também, as próteses dos indivíduos foram visualmente inspecionadas em relação à presença de biofilme. Outras condições das próteses analisadas clinicamente foram retenção, suporte, estabilidade, adaptação e desgaste dos dentes artificiais. 


\subsubsection{Critérios para a seleção da amostra}

Neste estudo, para a seleção da amostra, foram excluídos indivíduos portadores de próteses sem estabilidade e retenção, imunocomprometidos, com endocrinopatologias não controladas, usuários de antibióticos e submetidos a radio ou quimioterapia (NEPPELENBROEK et al., 2008).

\subsubsection{Estabelecimento dos grupos de estudo}

Ao final, 30 indivíduos, sendo 28 mulheres e 2 homens, foram selecionados, de acordo com o diagnóstico clínico positivo para EP e com os critérios de exclusão anteriormente mencionados.

A seguir, a amostra foi dividida de maneira randômica, sendo o pesquisador principal mascarado a tal divisão. Para isso, uma funcionária de um dos abrigos foi designada para realizar a divisão dos indivíduos em grupos, bem como distribuir os tratamentos.

Dessa maneira, os indivíduos foram divididos em cinco grupos $(n=6)$, de acordo com os tratamentos testados (Tabela 1).

Tabela 1 - Distribuição dos grupos de acordo com as substâncias testadas.

Grupos

Substâncias

G1 (Placebo)

Água destilada estéril

G2 (Controle positivo)

Nistatina Micostatin (100.000 Ul/ml)

G3

Extrato alcoólico de própolis a 20\%

G4

Gel de $P$. granatum Linné (Romã)

G5

Gel de U. tomentosa (Imuno-Max Gel) 
Antes do início dos tratamentos, cada paciente recebeu do pesquisador responsável uma escova dental e um dentifrício. Além disso, todos os traumas perceptíveis ocasionados pelas próteses em uso pelo paciente foram removidos por meio de pequenos desgastes nas bases de resina acrílica.

Também, neste momento, orientações por escrito quanto ao uso dos produtos foram repassadas aos pacientes e as suas respectivas cuidadoras (Anexo D). Todos os produtos testados nesta pesquisa foram prescritos três vezes ao dia, durante 14 dias, associados à escovação das próteses e da mucosa bucal com dentifrício. A aplicação tópica dos produtos na mucosa e na superfície interna da prótese foi recomandada através do uso de cotonetes limpos.

Ainda, foi informado a todos os indivíduos que aqueles que não tolerassem possíveis efeitos colaterais dos medicamentos ou que não quisessem mais participar da pesquisa, poderiam notificar o pesquisador responsável, sem nenhum constrangimento, e seriam excluídos da pesquisa.

\subsubsection{Obtenção dos medicamentos}

\subsubsection{Nistatina (Micostatin) e Gel de U. tomentosa (Imuno-Max Gel)}

Os medicamentos nistatina Micostatin (100.000 Ul/ml) e gel de $U$. tomentosa Imuno-Max Gel foram adquiridos em farmácias alopáticas da rede Droga-Rio, em Bauru, São Paulo, Brasil.

\subsubsection{Extrato alcoólico de Própolis a $20 \%$}

A própolis verde foi coletada do mel das abelhas Apis mellifera. Amostras brutas de própolis foram desidratadas e moídas, para que fossem transformadas em pó. A seguir 2,0 g desse pó foram misturados a $25 \mathrm{~mL}$ de etanol a $80 \%$ em um tubo de ensaio e agitada por $30 \mathrm{~min}$, a $70^{\circ} \mathrm{C}$. Posteriorm ente, essa mistura foi centrifugada a $8.000 \times \mathrm{g}$ para se obter os sobrenadantes, os quais foram utilizados como o extrato de própolis (SANTOS et al., 2005). A seguir, foram inseridos e identificados em frascos de $20 \mathrm{~mL}$. Todo o processo de elaboração deste medicamento foi realizado pela farmácia de manipulação Calêndula Farma, em Bauru, São Paulo. 


\subsubsection{Gel de P. granatum Linné}

O extrato de $P$. granatum Linné utilizado nesta pesquisa foi obtido como descrito por Vasconcelos et al. (VASCONCELOS et al., 2003) pela farmácia de manipulação Calêndula Farma, em Bauru, São Paulo. O extrato de $P$. granatum Linné foi preparado a partir da casca de frutos de romã. A extração dos marcadores químicos foi realizada por percolação em temperatura ambiente. $O$ extrato fluido foi preparado na proporção de 1:1 (peso/volume), em temperatura constante de $45^{\circ} \mathrm{C}$, em um sistema de rotação de vapor. Desse extrato foi produzido o gel de $P$. granatum Linné, o qual era formado basicamente por carbopol 940, trietanolamina e $0,5 \mathrm{ml}$ do extrato fluido. Quarenta gramas do gel apresentavam $0,5 \mathrm{ml}$ do extrato. A seguir, bisnagas plásticas de $20 \mathrm{~mL}$ foram preenchidas e identificadas com este produto.

\subsubsection{4 Água destilada estéril}

Após a esterilização da água destilada, frascos de vidro de $20 \mathrm{~mL}$ foram preenchidos com este produto. Para que não houvesse a identificação do produto placebo pelos pacientes, os fracos foram etiquetados também com o nome de Extrato alcoólico de Própolis a $20 \%$. Todo o processo de elaboração deste produto foi realizado pela farmácia de manipulação Calêndula Farma, em Bauru, São Paulo.

Para que o pesquisador pudesse identificar o produto placebo no momento das avaliações, foi realizada uma pequena marcação com tinta nas etiquetas dos frascos deste grupo.

\subsubsection{Avaliação clínica dos tratamentos}

Para avaliação clínica dos tratamentos testados, foi realizada cultura micológica quantitativa, a qual possibilita verificar o efeito das substâncias testadas sobre a carga fúngica de Candida spp. encontrada na mucosa palatina e na superfície interna da prótese.

Para isto, foram realizadas coletas de material das áreas eritematosas da mucosa palatina de cada indivíduo e das áreas, correspondentes aos eritemas, da superfície interna da prótese total superior. As coletas foram realizadas com swab 
oral estéril, sendo utilizado um swab para cada superfície avaliada. Em seguida, cada swab foi individualmente imerso em tubo de ensaio, previamente identificado, contendo 5,0 mL de solução salina estéril.

Em capela de fluxo laminar previamente desinfetada com álcool $70^{\circ}$, cada tubo de ensaio foi agitado vigorosamente por $1 \mathrm{~min}$ para promover a suspensão dos micro-organismos aderidos ao swab. Uma alíquota de $50 \mu \mathrm{L}$ da suspensão foi semeada com alça de Drigalsky estéril em uma placa de Petri contendo ágar Sabourand com $5 \mu \mathrm{g} / \mathrm{mL}$ de cloranfenicol. As placas de Petri foram incubadas a $3^{\circ} \mathrm{C}$ por 48 h, e, então, as colônias viáveis de Candida sp. contadas visualmente.

Após a contagem das colônias, os números de unidades formadoras de colônias (UFC/mL) foram calculados. Para esse cálculo, utilizou-se a fórmula a seguir:

$$
\mathrm{UFC} / \mathrm{mL}=\frac{\text { número de colônias } \times 10^{\mathrm{n}}}{\mathrm{q}}
$$

Nessa fórmula, $n$ equivale ao valor absoluto da diluição (1, 2, 3 ou 4), e q equivale à quantidade, em $\mathrm{mL}$, pipetada para cada diluição quando nas semeaduras das placas. No presente estudo, não houve a necessidade de diluição da alíquota, logo o número de colônias não foi multiplicado por nenhum fator de potência e o valor de q correspondeu a 0,05, uma vez que foram pipetados $50 \mu \mathrm{L}$ para cada plaqueamento. A mediana das 2 placas de cada espécime foi utilizada como valor final de contagem. Os valores médios de cada grupo foram devidamente catalogados para posterior avaliação estatística.

As culturas micológicas quantitativas foram realizadas, para todos os indivíduos, antes (T0) e ao final do tratamento, após 14 dias (T1). Para avaliar a efetividade de cada tratamento em longo prazo, culturas microbiológicas quantitativas foram também realizadas após 30 dias (T2) decorridos de sua suspensão.

Os procedimentos descritos para as culturas micológicas quantitativas foram realizados em duplicata, sendo obtidas, para cada indivíduo, duas placas de Petri da mucosa palatina e duas da superfície interna da prótese total superior em cada período de avaliação. 


\subsubsection{Análise estatística}

Os dados obtidos foram submetidos ao teste não-paramétrico de Friedman para comparações intragrupos e ao teste de Kruskal-Wallis para comparações intergrupos. Para todos os testes foi considerado um nível de significância de $5 \%$ $(p<0,05)$.

\subsection{Avaliação do efeito antifúngico de produtos naturais sobre biofilmes de $C$. albicans em uma resina acrílica termopolimerizável}

\subsubsection{Confecção dos espécimes}

\subsubsection{Confecção dos padrões de silicona}

Para confecção dos padrões de silicona, foi utilizada uma matriz metálica, de forma retangular, medindo $30 \mathrm{~mm}$ de comprimento, $5 \mathrm{~mm}$ de largura e $5 \mathrm{~mm}$ de altura. Cada matriz foi preenchida com silicona de condensação de uso laboratorial Zetalabor (Hard 85 shore-A, Zhermack, Italy) e prensada entre duas placas de vidro (JON Com. de produtos odontológicos LTDA, São Paulo, SP) previamente isoladas com vaselina sólida (Hemafarma Com. e Ind. farmacêutica LTDA, São Gonçalo, RJ), sob peso de $5 \mathrm{~kg}$, por aproximadamente $10 \mathrm{~min}$. Em seguida, o padrão de silicone foi removido da matriz e os excessos foram cortados com auxílio de uma lâmina de bisturi.

\subsubsection{Inclusão dos padrões de silicona}

Os padrões de silicona foram incluídos em muflas de latão polido com pino n 6 (Mac Artigos odontológicos e prótese Ind. e Com. LTDA, São Paulo, SP), anteriormente isoladas com vaselina sólida. Posteriormente, as muflas metálicas foram preenchidas com gesso pedra tipo III (Gesso Pedra Herodent, Vigodent S/A Ind. e Com., Rio de Janeiro, RJ), manipulado e espatulado conforme orientações do fabricante, em cuba de borracha (Dentalbrand Comercial, São Paulo, SP) com 
espátula para gesso (Indusbello Ind. de Instr. Odontológicos, Londrina, PR), sob vibração.

Após a presa, os padrões de silicona foram colocados sobre o gesso e uma nova camada deste foi colocada entre eles, a fim de fixá-los na mufla. Esperado o tempo de presa da segunda camada, em seguida, foi aplicado o isolante Cel-Lac (S.S. White Artigos Dentários, Rio de Janeiro, RJ) em toda superfície. A contra-mufla também recebeu uma camada de vaselina sólida nas suas superfícies internas e posteriormente, foi posicionada e devidamente preenchida com gesso pedra tipo III, conforme condições técnicas descritas anteriormente.

As muflas permaneceram na prensa hidráulica (VH Equipamentos médicos Odont. Acess. LTDA., Araraquara, SP) com 0,5 Kgf de pressão, por uma hora, e em seguida, foram abertas para a remoção das matrizes de silicone e realização do exame do molde no gesso, a fim de verificar a presença de bolhas.

\subsubsection{Preenchimento dos moldes, termopolimerização e acabamento} dos bastões de resina acrílica

Para prensagem, foi utilizada a resina acrílica incolor termopolimerizável Lucitone 550 (Dentsply International INC., Chicago, IL, USA), homogeneizada com auxílio de uma espátula n³1 (SS White Art. Dentár ios LTDA, Rio de Janeiro, RJ) em recipiente de vidro (Paladon, Pr. Ind. e Comércio de produtos odontológicos, Florianópolis, SC), utilizando-se a proporção de $21 \mathrm{~g}$ de pó para $10 \mathrm{~mL}$ de líquido, conforme orientações do fabricante. O interior dos moldes de gesso foi isolado com isolante Cel Lac, com auxílio de um pincel de pêlo de marta (Condor, n\%456, Condor S.A., São Bento do Sul, SC) e preenchido com a resina acrílica na fase plástica. A base da mufla foi coberta com uma folha de papel celofane e fechada com a sua respectiva porção superior para ser prensada em prensa hidráulica sob pressão inicial de 0,5 kgf. No momento em que o ponteiro da prensa hidráulica apresentou-se estável, a pressão foi aumentada para $1 \mathrm{kgf}$ e por fim, até atingir 1,5 kgf. Após a estabilização do ponteiro em 1,5 kgf e escoamento completo do excesso da resina acrílica, a mufla foi novamente aberta, o papel celofane removido, e a película de resina acrílica excedente eliminada com o auxílio de uma espátula Lecron (S.S. White Art. Dentários LTDA, Rio de Janeiro, RJ). A mufla foi novamente fechada e levada para prensa hidráulica sob pressão de 1,5 kgf durante $30 \mathrm{~min}$. 
Decorrido esse período, a mufla foi colocada em uma prensa de aço inoxidável (Metal Vander Aparelhos para Ortodontia, Piracicaba, SP), passível de ser utilizada em polimerizadoras digitais, e levada, em água, à polimerizadora microprocessada digital, modelo Banho Maria (Solab, Piracicaba, SP), para que se processasse a termopolimerização com a seguinte programação: a temperatura da água se elevou até $73^{\circ} \mathrm{C}$ e se estabilizou durante $90 \mathrm{~min}$, em seguida, tornou a subir até atingir $100^{\circ} \mathrm{C}$, que foram mantidos por mais $30 \mathrm{~m}$ in

Ao final da demuflagem, foram obtidos bastões de resina acrílica, nos quais foi dado o acabamento com o auxílio de fresa de tungstênio em baixa velocidade (SARTORI et al., 2006).

\subsubsection{Lixamento dos bastões de resina acrílica, avaliação da} rugosidade superficial, seccionamento e esterilização dos espécimes

Cada bastão de resina acrílica teve uma face escolhida, na qual foi realizado o lixamento manual, em forma de oito (VERRAN e MARYAN, 1997), por cerca de 30 segundos, por meio de lixa d'água (Norton Abrasivos, São Paulo, SP) na granulação 120 em politriz circular (Dp-10, Struers-Panambra, São. Paulo, SP, Brasil), em baixa velocidade, sob refrigeração.

Durante ensaios iniciais desta pesquisa, foram realizadas leituras, por meio de rugosímetro, na superfície mais crítica para higienização das próteses totais, a superfície interna, obtendo-se uma média entre 1-2 $\mu \mathrm{m}$. Baseado nisto, esta mesma média de rugosidade superficial foi determinada na face lixada dos bastões de resina, sendo mensurada através do aparelho rugosímetro Hommel Tester T 1000 basic (Hommelwerke $\mathrm{GmbH}$, ref. \# 240851, Schwenningen, Germany). A leitura considerada foi a média aritmética $(\mathrm{Ra})$ entre os picos e vales percorridos pela ponta ativa do aparelho, onde o percurso de medição foi de $4,8 \mathrm{~mm}$, comprimento de onda limite $0,8 \mathrm{~mm}$ e velocidade de $0,5 \mathrm{~mm} / \mathrm{s}$. Foram realizadas seis leituras na superfície lixada de cada bastão de resina acrílica (RAHAL et al., 2004).

Paralelamente à face rugosa de cada bastão, por meio de um disco diamantado (Extec dia. wafer blade 4"x.012 x 1/2 high concen., Erios, São Paulo, SP Brasil), foi obtida uma lâmina de resina acrílica (30mm x $5 \mathrm{~mm} \times 1 \mathrm{~mm})$. Cada lâmina sofreu uma redução no seu comprimento, através do seu seccionamento em 5 partes iguais, dando origem aos espécimes propriamente ditos, medindo $5 \mathrm{~mm} \mathrm{x}$ 
$5 \mathrm{~mm} \times 1 \mathrm{~mm}$ (LAMFON et al., 2003; SILVA et al., 2011). Ao final, foram confeccionados 30 espécimes.

Em seguida, os espécimes foram submetidos à limpeza em ultrassom (Ultrasonic Cleaner, Arotec, Odontobrás, São Paulo, Brasil) por 20 min (PEREIRACENCI et al., 2007) em água destilada, para remoção dos debris da superfície da resina.

Posteriormente, os espécimes foram deixados em ar livre para secar e, em seguida, embalados individualmente para esterilização por meio de óxido de etileno (Acecil Central de esterilização comércio e indústria, Campinas, SP) (SILVA et al., 2006; MIMA et al., 2008).

\subsubsection{Inoculação dos espécimes}

\subsubsection{Micro-organismos e condições de crescimento}

Todos os procedimentos microbiológicos foram realizados sempre em condições assépticas, em capela de fluxo laminar previamente desinfetada com álcool $70^{\circ}$.

Neste estudo, foram utilizadas cepas de C. albicans ATCC 90028 para formação do biofilme sobre os espécimes.

As cepas foram reativadas de sua cultura original (TSB, Accumedia Manufacturers, Inc.Lansing, MI, USA) a $-70^{\circ} \mathrm{C}$, em $10 \mathrm{ml}$ de meio de cultura TSB caldo (CAMPANHA et al., 2007) com Cloranfenicol (Quemicetina Succinato/ Carlo Erba®, Milano, MI, Itália), e incubadas s durante $24 \mathrm{~h}$ a $37^{\circ} \mathrm{C}$ em estufa (Orion, Fanem, São Paulo, SPI), em condições aeróbicas. Após 24 h, foi realizada a centrifugação (Centrifuge 5804R, Eppendorf) da suspensão por $10 \mathrm{~min}$, com velocidade de $5.000 \mathrm{rpm}$, a $22^{\circ} \mathrm{C}$, para separação dos micro-organismos do sobrenadante. Os fungos isolados foram lavados 2 vezes em PBS (Mercker) para remoção de impurezas e o pelet final foi resuspenso em PBS. A seguir, a suspensão foi agitada por 15 segundos e a turbidez foi ajustada espectrofotometricamente (Pharmacia Biotech, Ultraspec 100, New Jersey, USA), a 600 nm, até atingir absorbância similar ao padrão 0,5 da escala McFarland. Este procedimento assegurou a preparação de uma suspensão celular com uma concentração final de 
$1 \times 10^{7} \mathrm{cels} / \mathrm{mL}$ em TSB com cloranfenicol concentração ótima para formação de biofilme (CHANDRA et al., 2001b)

\subsubsection{Formação do biofilme}

Utilizando uma pinça estéril (S.S. White Art. Dentários LTDA, Rio de Janeiro, RJ), cada espécime foi colocado em um poço de uma placa de cultura celular de 24 poços (TPP, Switzerland), no qual foi dispensado $1 \mathrm{~mL}$ da suspensão celular, através de pipetas de precisão e ponteira descartáveis, deixando os espécimes totalmente submersos. Inicialmente, todos os espécimes foram deixados em cultura com as espécies fúngicas testadas por 90 min em estufa (Orion, Fanem, São Paulo, Brasil) a $37^{\circ} \mathrm{C}$ sob agitação. Cabe ressalta que, assim como todo estudo in vitro, o presente trabalho também apresentou limitações, sendo que a principal delas é a ausência do fluxo salivar, importante no controle do acúmulo de placa microbiana. Diante disso, durante todo o período em que os espécimes foram mantidos em meio de cultura, as placas de cultura de ensaio que os mantinham foram mantidas sob movimentação constante, com o objetivo de evitar o acúmulo das células fúngicas em uma única área por deposição e não por aderência o que foi o desejado neste estudo. Além disso, de acordo com Thein, Samaranayake e Samaranayake (THEIN, SAMARANAYAKE e SAMARANAYAKE, 2007), há uma maior formação de biofilme de fúngico em ambiente dinâmico do que em meio estático.

Cessado os $90 \mathrm{~min}$, os espécimes foram individualmente e suavemente lavados três vezes em $2 \mathrm{~mL}$ de PBS (HAWSER e DOUGLAS, 1994) para garantir a remoção de células não aderidas ao material (KUHN et al., 2002). A seguir, os espécimes foram reinseridos em $1 \mathrm{~mL}$ de TSB com cloranfenicol e incubados em estufa a $37^{\circ} \mathrm{C}$ sob agitação por $24 \mathrm{~h}$ (KUMAMOTO, 2002; PEREIRA-CENCI et al., 2008) para o desenvolvimento do biofilme.

Apesar do período do tratamento da EP com as drogas testadas ser de 14 dias, a avaliação do efeito antifúngico destas substâncias foi realizada em biofilmes com $24 \mathrm{~h}$ de formação, uma vez que há um aumento do nível de morte celular após este período, devido à competição por nutrientes entre as células. Deste modo, tal fato poderia superestimar o efeito antifúngico das substâncias testadas. 


\subsubsection{Aplicação das substâncias testadas}

Após a formação do biofilme, todos os espécimes foram imersos, individualmente, em $1 \mathrm{~mL}$ da substância relativa ao seu grupo por $1 \mathrm{~min}$. Posteriormente, cada espécime foi suavemente imerso 3 vezes consecutivas (THERAUD et al., 2004) em 3 diferentes poços da placa de cultura, com $2 \mathrm{~mL}$ de PBS em cada poço, para a remoção das substâncias testadas e de possíveis células planctônicas.

\subsubsection{Estabelecimento dos grupos de estudo}

Os 30 espécimes foram divididos aleatoriamente em 5 grupos $(n=6)$, de acordo como já descrito anteriormente no item 3.1.4 deste trabalho (Tabela 1).

\subsubsection{Obtenção dos medicamentos}

Essa etapa foi realizada de maneira idêntica ao item 3.1.5 deste trabalho.

\subsubsection{Processamento dos espécimes para microscopia confocal}

Como a análise no microscópio confocal não permite a observação de mais de um espécime por vez, cada espécime foi processado de forma particular.

Assim, concluída a lavagem em PBS, cada espécime foi transferido para um poço da placa de cultura de tecidos de 24 poços, contendo $1 \mathrm{~mL}$ de PBS, misturado com $1 \mu \mathrm{M}$ do fluorocromo SYTO-9 e $1 \mu \mathrm{M}$ do fluorocromo iodeto de propídeo (LIVE/DEAD® Viability Assay Kit, Molecular Probes, Invitrogen Brasil Ltd., São Paulo, SP). Na sequência, foram aguardados $20 \mathrm{~min}$ para que haja a difusão dos fluorocromos no biofilme (JIN et al., 2005). Este processo foi realizado na ausência de luz a $37^{\circ} \mathrm{C}$, de acordo com as orientações do fabricante.

Imediatamente após o período de incubação, cada espécime foi cuidadosamente montado em lamínula de vidro associada a óleo de imersão, com a face rugosa para baixo, para análise do biofilme em microscópio confocal Leica TCS SPE (Leica Microsystems GmbH, Mannheim, Germany). A objetiva usada foi uma lente de imersão em óleo (40x; abertura numérica de 1,15). 


\subsubsection{Análise dos espécimes no microscópio confocal}

Em cada espécime, a aquisição das imagens foi realizada de maneira padronizada em 6 diferentes campos (SMITH e HUNTER, 2008), de acordo com a figura 1, a fim de que não haja a possibilidade de análise de um mesmo campo repetidas vezes.

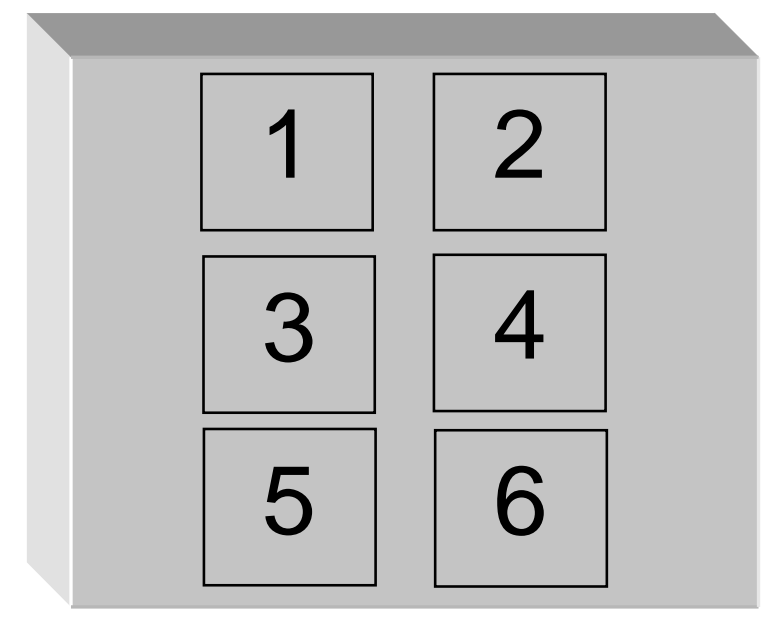

Figura 1 - Sequência padrão de análise dos 6 campos dos espécimes no microscópio confocal.

Para a análise das células do biofilme de cada campo, foi realizada a tomada de uma série de secções ópticas horizontais, com $1 \mu \mathrm{m}$ de intervalo, por toda a profundidade do biofilme. De cada secção foram adquiridas duas imagens, de forma sequencial. Para o SYTO-9 foi usada a excitação em 488 nm, e o detector espectral foi programado para a faixa de 495 a $575 \mathrm{~nm}$. Para o lodeto de Propídeo, a excitação foi em 532 nm, e a detecção entre 595 e 730 nm. A aquisição sequencial elimina qualquer interferência que possa existir do fluorocromo verde sobre 0 vermelho (cross-talk). O programa utilizado para a aquisição das imagens foi o Leica LAS AF (Leica Microsystems GmbH, Mannheim, Germany). Posteriormente, também através deste programa, foi realizada a união das duas imagens de cada secção, assim como, o agrupamento de todas as secções de cada campo, gerando uma imagem final, onde foi possível identificar as células viáveis e não viáveis em cada campo do espécime (SILVA et al., 2011).

As células viáveis, sem comprometimento de membrana citoplasmática, apresentaram coloração verde, indicando que somente o SYTO-9 estava presente no seu interior. As células não viáveis, com comprometimento de membrana 
citoplasmática celular, apresentaram coloração amarelo-avermelhada, indicativa da presença do SYTO-9 e do iodeto de propídeo no seu interior.

A porcentagem de micro-organismos viáveis e não viáveis em cada campo de cada espécime foi realizada através do programa ImageJ 1.38x (National Institutes of Health, EUA) (PEREIRA-CENCl et al., 2008). Os valores médios de cada grupo encontrados foram catalogados para posterior análise estatística.

\subsubsection{Análise estatística}

Os dados obtidos pelo microscópio confocal, relativos ao desempenho das substâncias testadas sobre $C$. albicans presentes em biofilme sobre resina acrílica, foram analisados através do teste não paramétrico de Kruskal-Wallis e do pós-teste de comparação múltipla de Dunn, com nível de significância estabelecido em 5\% $(\mathrm{p}<0,05)$.

\subsection{Avaliação laboratorial do efeito de produtos naturais sobre a rugosidade superficial e na microdureza de uma resina acrílica termopolimerizável}

\subsubsection{Confecção dos espécimes}

A confecção dos espécimes foi realizada de forma idêntica as etapas 3.2.1.2, 3.2.1.3 e 3.2.1.4 deste trabalho. As diferenças neste procedimento serão descritas nos itens a seguir.

\subsubsection{Polimento dos bastões de resina}

Os bastões de resina acrílica obtidos foram polidos com auxílio de uma politriz metalográfica mecânica (APL 4, Arotec, Cotia, SP) com dispositivo para polimentos múltiplos, capaz de realizar um polimento simultâneo com refrigeração de água em seis bastões de resina, proporcionando o paralelismo entre as superfícies polidas. $O$ tamanho dos bastões $(30 \times 5 \times 5 \mathrm{~mm})$ permitiu a completa adaptação dos mesmos aos orifícios onde se encaixaram os elementos a serem polidos na politriz metalográfica. 
As duas faces de cada bastão foram polidas de maneira idêntica. $O$ polimento de cada face se iniciou com lixa de silicone carbide de granulação 320 , acionando-se a politriz em alta velocidade, com carga máxima de $215 \mathrm{~g}$, durante 4 min. A seguir, foi realizado o polimento com as lixas de granulação 600 e 1200, também com a carga máxima de $215 \mathrm{~g}$, durante 4 min, sempre com a politriz em alta velocidade. Para o polimento final, foi utilizado um feltro (Extec Corp., Enfield, USA) umedecido com suspensão de alumina de 0,3 $\mu$ m (Buehler, Enfield, USA), por 4 min em alta velocidade, com carga de $215 \mathrm{~g}$, sem refrigeração (PINTO et al., 2010).

Com o objetivo de impedir que os grãos das primeiras lixas pudessem interferir na qualidade do polimento das seguintes, a cada troca de granulometria, os bastões de resina foram levados em uma lavadora ultrassônica (T7 Thornton, Unique Ind. e Com. de Produtos Eletrônicos LTDA, São Paulo, SP), com frequência de $40 \mathrm{~Hz}$, durante $2 \mathrm{~min}$, com água deionizada e posteriormente foram secos com papel toalha (PINTO et al., 2010).

\subsubsection{Obtenção dos espécimes de resina acrílica e armazenamento} em água

Ao final, foram obtidos 50 espécimes de resina acrílica termopolimerizável. Em cada espécime de resina, uma face foi destinada à análise da rugosidade e a outra da microdureza.

Previamente à realização dos testes iniciais de microdureza e de rugosidade superficiais, os espécimes serão armazenados em recipientes plásticos tampados, por um período de $48 \mathrm{~h}$ em água deionizada a $37^{\circ} \mathrm{C}$, c onforme as normas da ADA (American Dental Association, 1975) e ISO (International Organization for Standartization Specification 1567, 1988) (PINTO et al., 2010).

\subsubsection{Estabelecimento dos grupos de estudo}

Após o período de armazenagem em água, os espécimes foram divididos aleatoriamente em 5 grupos $(n=10)$, de acordo como já descrito anteriormente no item 3.1.4 deste trabalho (Tabela 1). 


\subsubsection{Obtenção dos medicamentos}

Essa etapa foi realizada de maneira idêntica ao item 3.1.5 deste trabalho.

\subsubsection{Aplicação das substâncias testadas}

Cada espécime foi imerso por $24 \mathrm{~h}$ em $1 \mathrm{~mL}$ de sua respectiva substância, dentro de um microtubo tipo Eppendorf e, posteriormente, hermeticamente fechado ao abrigo da luz. A cada $24 \mathrm{~h}$, foi realizada a troca da substância testada. Este procedimento foi repetido durante 14 dias (BLOMGREN, BERGGREN e JONTELL, 1998), simulando o período de utilização dessas substâncias no tratamento da EP.

\subsubsection{Avaliação da rugosidade superficial}

A rugosidade superficial média de uma face de cada espécime foi mensurada através de rugosímetro Surf Corder SE 1700 (Kosakalab, Tókio, Japão) agulha com precisão de 0,0001 $\mu \mathrm{m}$, velocidade de percurso de 0,5 mm/s. Em cada espécime foram realizadas 3 mensurações com $9 \mathrm{~mm}$ de comprimento em três diferentes posições (direita, média, esquerda).

A rugosidade superficial (Ra- $\mu \mathrm{m}$ ) de cada espécime foi avaliada antes (T0) e após o período total de contato com as substâncias testadas neste estudo (T1).

\subsubsection{Avaliação da microdureza superficial}

A microdureza superficial Knoop (KHN) média de uma face cada espécime foi mensurada por meio de um microdurômetro (Shimadzu, modelo HMV-2000, Kyoto, Japão), com carga de 25 gramas e tempo de aplicação de 25 segundos. Em cada espécime foram realizadas 3 mensurações (direita, média, esquerda).

A microdureza superficial de cada espécime foi avaliada antes (T0) e após o período total de contato com as substâncias testadas neste estudo (T1). 


\subsubsection{Análise estatística}

A variação intragrupos na rugosidade e na microdureza foi avaliada através do teste t pareado. A avaliação intergrupos quanto ao efeito dos diferentes produtos testados na rugosidade e na microdureza foi realizada através da análise de variância (ANOVA), seguida de teste de Tukey. Para todos os testes foi considerado um nível de significância de $5 \%(p<0,05)$. 




\section{RESULTADOS}

\subsection{Avaliação clínica do efeito antifúngico de produtos naturais no tratamento da EP}

\subsubsection{Na mucosa do palato}

Tabela 2 - Mediana e desvio interquarlítico (DI) utilizados na comparação intragrupos (Friedman) e intergrupos (Kruskal-Wallis) nos tempos avaliados para as células coletadas na mucosa do palato (UFC/ml).

\begin{tabular}{ccccc}
\hline \hline Grupos & T0 & T1 & T2 & p (Friedman) \\
\hline \multicolumn{5}{c}{ Med \pm DI } \\
\hline G1 & $40.0 \pm 84.0^{\mathrm{a}, \mathrm{A}}$ & $9.5 \pm 1.8^{\mathrm{b}, \mathrm{A}}$ & $10.5 \pm 2.5^{\mathrm{a}, \mathrm{b}, \mathrm{A}}$ & 0.005 \\
\hline G2 & $75.5 \pm 48.0^{\mathrm{a}, \mathrm{A}}$ & $1.0 \pm 1.5^{\mathrm{b}, \mathrm{A}}$ & $7.5 \pm 12.7^{\mathrm{a}, \mathrm{b}, \mathrm{A}}$ & 0.009 \\
\hline G3 & $62.5 . \pm 45.1^{\mathrm{a}, \mathrm{A}}$ & $4.2 \pm 5.7^{\mathrm{b}, \mathrm{A}}$ & $6.7 \pm 7.6^{\mathrm{a}, \mathrm{b}, \mathrm{A}}$ & 0.005 \\
\hline G4 & $50.5 \pm 52.3^{\mathrm{a}, \mathrm{A}}$ & $5.2 \pm 9.3^{\mathrm{b}, \mathrm{A}}$ & $2.7 \pm 9.0^{\mathrm{b}, \mathrm{A}}$ & 0.01 \\
\hline G5 & $67.5 . \pm 64.6^{\mathrm{a}, \mathrm{A}}$ & $5.2 \pm 11.5^{\mathrm{b}, \mathrm{A}}$ & $7.5 \pm 3.5^{\mathrm{a}, \mathrm{b}, \mathrm{A}}$ & 0.005 \\
\hline $\begin{array}{c}\text { p (Kruskal- } \\
\text { Wallis) }\end{array}$ & 0.98 & 0.46 & $0.88^{2}$ & \\
\hline \hline
\end{tabular}

Letras minúsculas iguais nas linhas indicam que os grupos são estatisticamente semelhantes; Letras maiúsculas iguais nas colunas indicam que os grupos são estatisticamente semelhantes $(p<0,05)$.

A análise da tabela 2 demonstrou significante redução dos valores de UFC/ml em T1, em todos os grupos, quando comparados com T0 ( $p<0,05)$. Quando comparados T1 com T2, foi observado um aumento nos valores de UFC/ml em todos os grupos, exceto para o grupo G4, o qual apresentou manutenção na inibição fúngica. Apesar disso, não foram detectadas diferenças significativas para todos os grupos quando comparados T2 e T1. Além disso, verificou-se que não houve diferença estatística significante entre os diferentes grupos em cada tempo testado $(p>0,05)$. 


\subsubsection{Na superfície interna da prótese}

Tabela 3 - Mediana e desvio interquarlítico (DI) utilizados na comparação intragrupos (Friedman) e intergrupos (Kruskal-Wallis) nos tempos avaliados para as células coletadas na superfície interna da prótese (UFC/ml).

\begin{tabular}{ccccc}
\hline \hline Grupos & T0 & T1 & T2 & p (Friedman) \\
\hline G1 & $1.2 \pm 8.5$ & $0.2 \pm 0.8$ & $0.5 \pm 2.8$ & 0.22 \\
\hline G2 & $2.0 \pm 23.8$ & $0.0 \pm 0.7$ & $0.0 \pm 3.7$ & 0.27 \\
\hline G3 & $9.7 \pm 12.8$ & $0.0 \pm 0.7$ & $0.7 \pm 2.2$ & 0.12 \\
G4 & $3.2 \pm 14.1$ & $0.0 \pm 0.7$ & $0.0 \pm 0.7$ & 0.31 \\
\hline G5 & $0.7 \pm 10.1$ & $0.0 \pm 1.5$ & $0.0 \pm 0.7$ & 0.32 \\
\hline $\begin{array}{c}p \text { (Kruskal- } \\
\text { Wallis) }\end{array}$ & 0.90 & 0.99 & 0.96 & \\
\hline \hline
\end{tabular}

A análise da tabela 3 não demonstrou redução significativa dos valores iniciais de $\mathrm{UFC} / \mathrm{mL}$ em todos os grupos testado, em relação aos demais tempos de avaliações. Ademais, verificou-se que não hove diferença estatisticamente significante entre os diferentes grupos em cada tempo analisado $(p>0,05)$. 


\subsection{Avaliação do efeito antifúngico de produtos naturais sobre biofilmes de $C$. albicans em uma resina acrílica termopolimerizável}

A análise das imagens obtidas por meio do microscópio confocal possibilitou perfeitamente a distinção entre as células viávies (verdes) e não viáveis (vermelhas) presentes nos biofilmes sobre os espécimes dos diferentes grupos testados e, por consequência, permitiu a contagem destas células através do software ImageJ.

Quanto às características morfológicas, em todos os grupos analisados, observou-se que as células fúngicas se apresentaram tanto na forma cilíndrica ou oval, típica de levedura (fungos leveduriformes), quanto na forma de levedura, na forma tubular ou filamentosa, típica de hifa (fungos filamentosos).

Amostras das imagens geradas pelo microscópio confocal dos biofilmes expostos às diferentes substâncias utilizadas nesta pesquisa podem ser observadas nas figuras 2 a 6 .
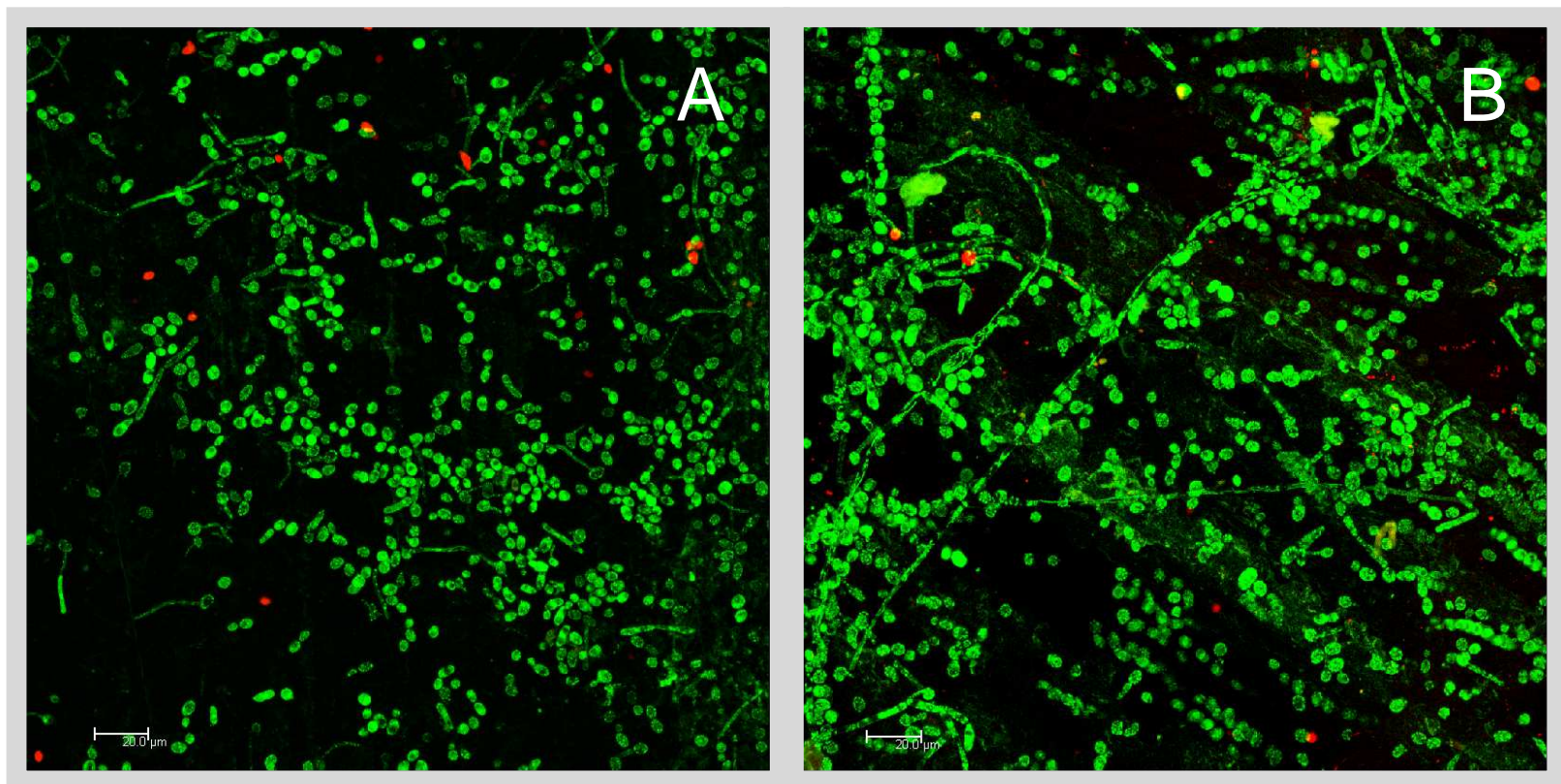

Figura 2. Imagens do biofilme de $C$. albicans sobre resina acrílica termopolimerizável tratado com água destilada por 1 minuto (grupo controle). (A-B) Biofilme rico em células viáveis (verdes), com reduzido número de células não viáveis (vermelhas). 


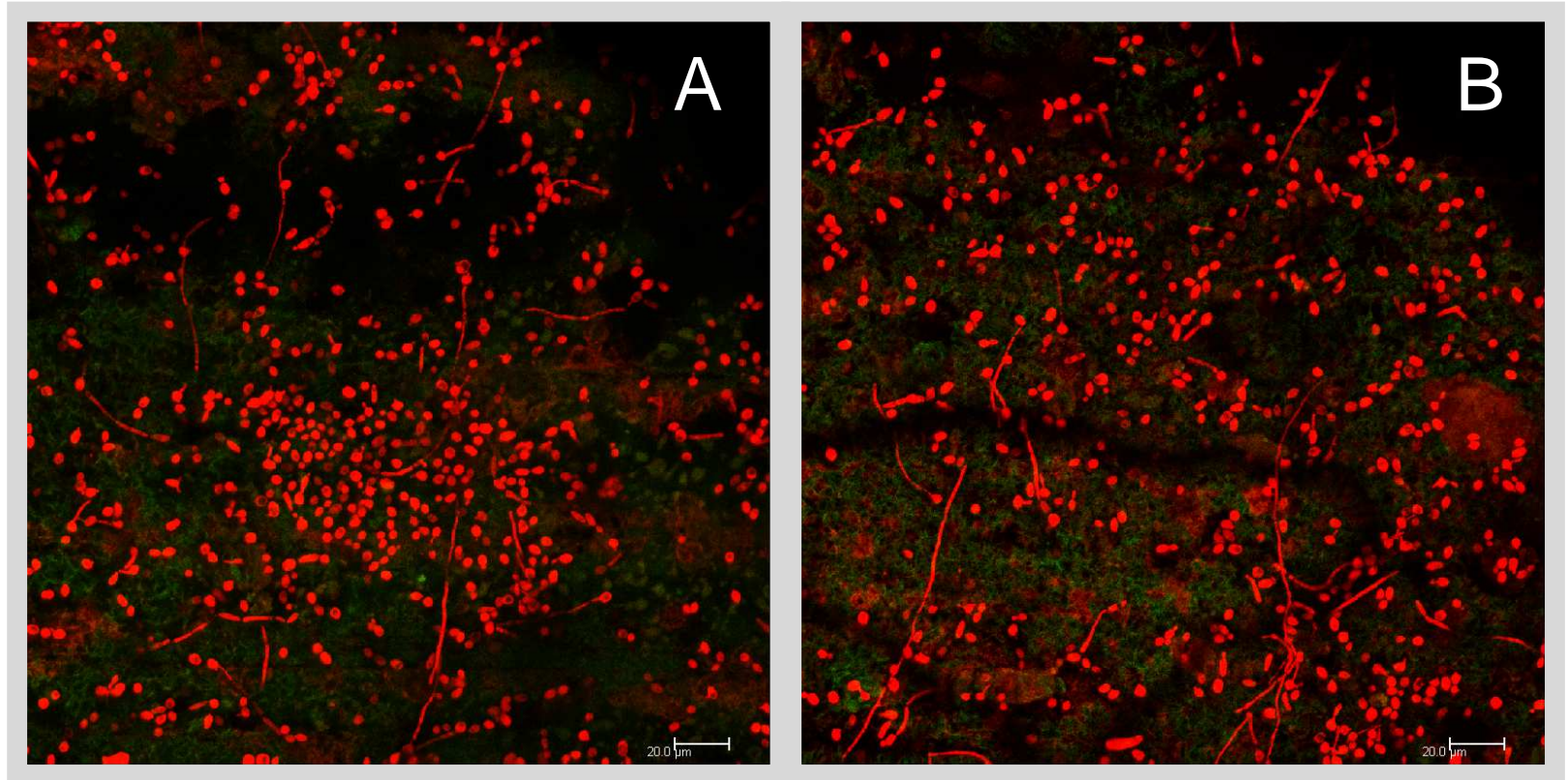

Figura 3. Imagens do biofilme de $C$. albicans sobre resina acrílica termopolimerizável após o tratamento com nistatina por 1 minuto. (A-B) Biofilme rico em células não viáveis (vermelhas), sem a presença de células viáveis (verdes).
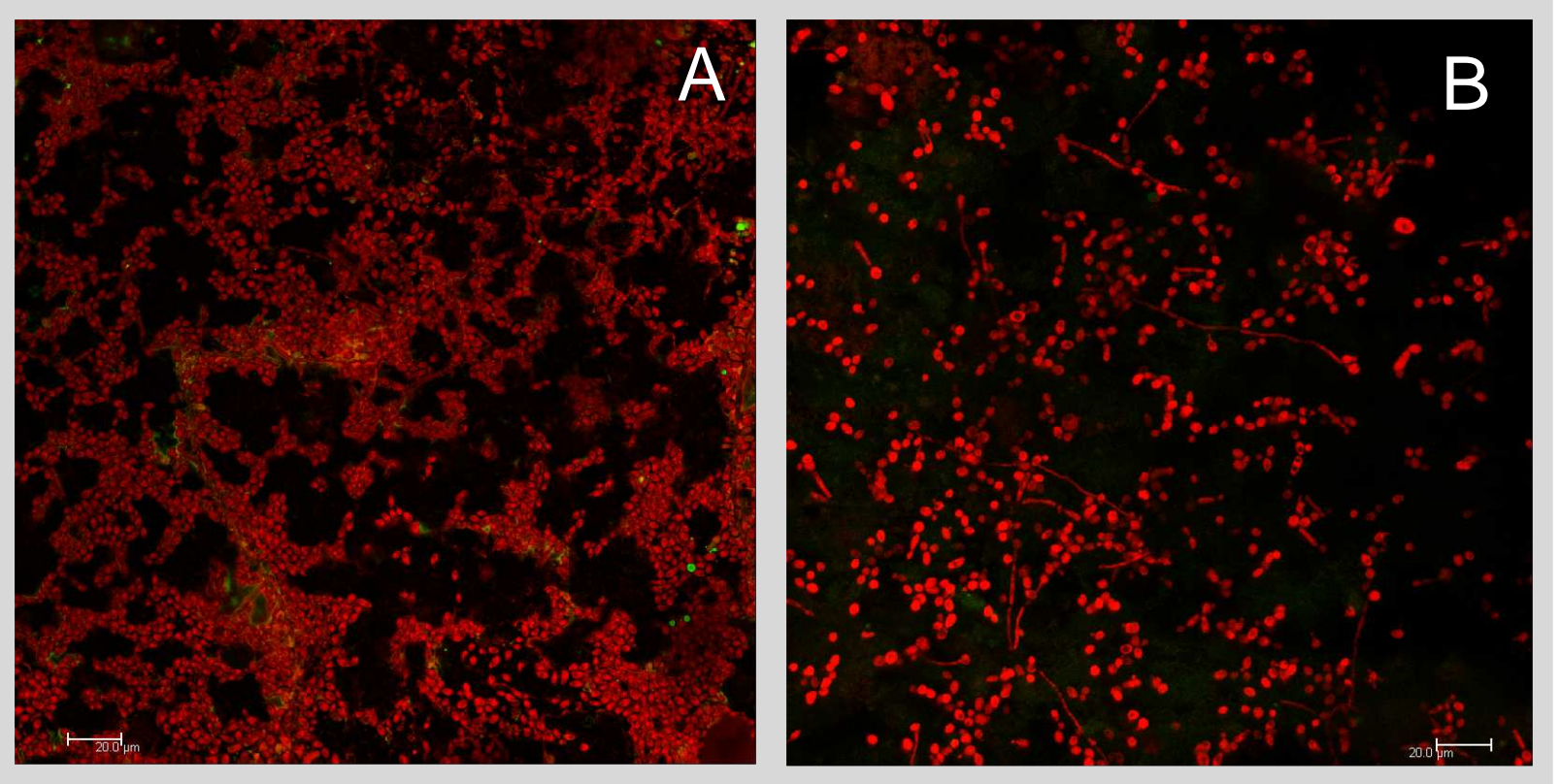

Figura 4. Imagens do biofilme de $C$. albicans sobre resina acrílica termopolimerizável após o tratamento com extrato alcoólico de própolis a $20 \%$ por 1 minuto. (A-B) Biofilme rico em células não viáveis (vermelhas), sem a presença de células viáveis (verdes). 



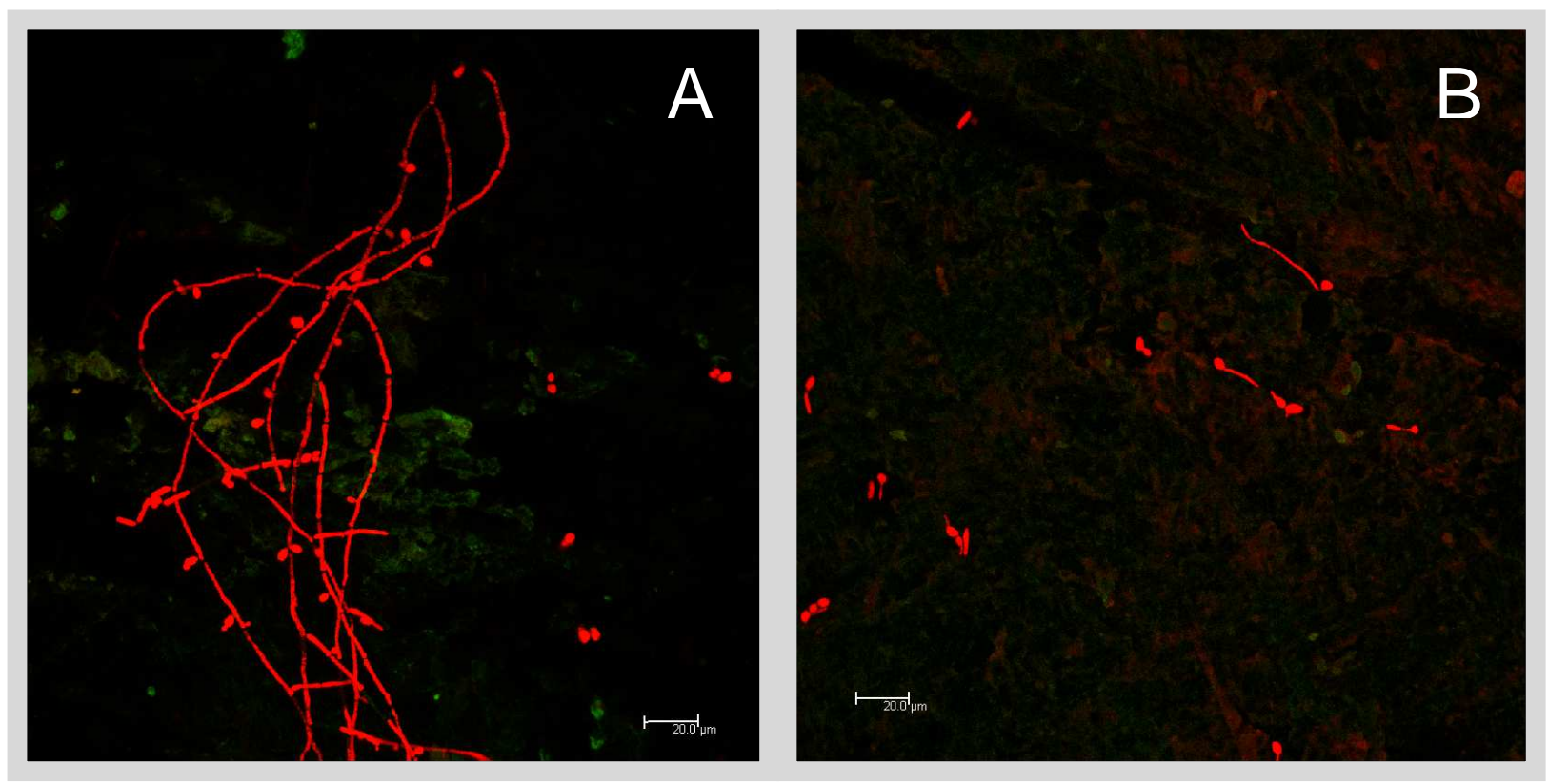

Figura 5. Imagens do biofilme de C. albicans sobre resina acrílica termopolimerizável após o tratamento com gel de $P$. granatum Linné por 1 minuto. (A-B) Biofilme com reduzido número de células não viáveis (vermelhas), sem a presença de células não viáveis (verdes).
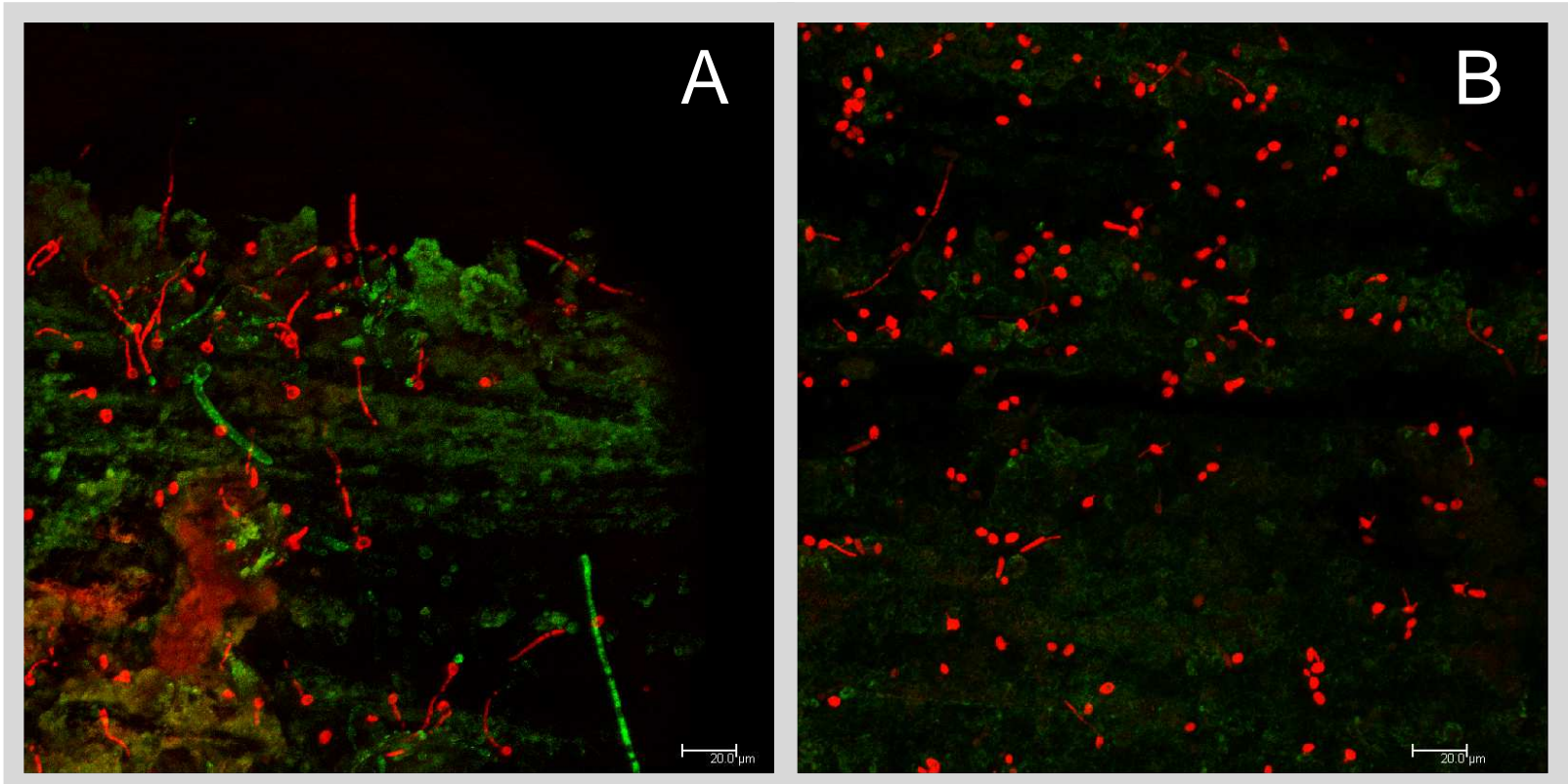

Figura 6. Imagens do biofilme de C. albicans sobre resina acrílica termopolimerizável após o tratamento com gel de $U$. tomentosa por 1 minuto. (A-B) Biofilme rico em células não viáveis (vermelhas), com reduzido número de células viáveis (verdes). 



\subsubsection{Análise quantitativa}

Tabela 4 - Mediana e desvio interquarlítico (DI) utilizados na análise de teste de KruskalWallis com post-hoc de Dunn para comparação intergrupos em relação ao número de células viáveis, não viáveis e total de células.

\begin{tabular}{|c|c|c|c|c|c|c|}
\hline Grupos & G1 & G2 & G3 & G4 & G5 & p \\
\hline \multicolumn{7}{|c|}{ Med \pm DI } \\
\hline Viáveis & $2.839 \pm 928^{a}$ & $0 \pm 0^{b}$ & $0 \pm 0^{b}$ & $0 \pm 0^{b}$ & $39 \pm 31^{b}$ & 0.0006 \\
\hline Não viáveis & $13 \pm 11^{c}$ & $2.475 \pm 2049^{a}$ & $2.874 \pm 1004^{a}$ & $120 \pm 228^{b, c}$ & $915 \pm 240^{a, b, c}$ & 0.0006 \\
\hline Total & $2.858 \pm 935^{a}$ & $2.475 \pm 2049^{a}$ & $2.874 \pm 1004^{a}$ & $120 \pm 228^{b}$ & $928 \pm 245^{a, b}$ & 0.0015 \\
\hline
\end{tabular}

Letras iguais nas linhas indicam que os grupos são estatisticamente semelhantes $(p<0,05)$.

Em relação ao número de células viáveis, os resultados da tabela 4 indicam que houve diferença estatística entre o grupo G1, o qual apresentou o maior valor, e os grupos G2, G3 e G4, os quais não apresentaram células viáveis $(p<0,05)$. Também, pode ser observado um número reduzido de céluas viáveis no grupo G5, o qual não foi estatisticamente diferente em relação os grupos G2, G3 e G4, os quais não apresentaram células viáveis $(p>0,05)$.

No tocante ao número de células não viáveis, os dados demonstraram elevado número de células nos grupos G2, G3 e G5, não havendo diferença estatística entre estes grupos ( $p>0,05$ ). No grupo $G 4$, notou-se significante redução do número de células não viáveis em relação aos grupos G2 e G3, no entanto, sem diferença estatística em relação ao grupo G5. No grupo G1, observou-se o menor valor de células não viáveis, porém, foram semelhantes estatisticamente aos grupos G4 e G5.

No que se refere ao total de células remanescentes, notou-se elevado número nos grupos G1, G2, G3, sendo estatisticamente semelhantes entre si. Apesar da redução no número total de células no grupo G5, não houve diferença estatística em relação aos grupos G1, G2 e G3. No grupo G4 notou-se significante 
diferença no número total de células em relação aos grupos G1, G2 e G3, contudo, este valor foi semelhante estatisticamente ao grupo G5.

\subsection{Avaliação laboratorial do efeito de produtos naturais sobre a rugosidade superficial e na microdureza de uma resina acrílica termopolimerizável}

Tabela 5 - Médias e desvios padrão (DP) utilizados na comparação intragrupos da rugosidade superficial dos espécimes antes (T0) e depois (T1) das aplicações dos produtos testados (Teste t pareado).

\begin{tabular}{cccc}
\hline \hline Grupos & Rugosidade T0 & Rugosidade T1 & Pédia \pm DP \\
\hline \multicolumn{1}{c}{ Me } & 0.282 \\
\hline G1 & $0.065 \pm 0.05^{a}$ & $0.069 \pm 0.02^{a}$ & 0.252 \\
\hline G2 & $0.056 \pm 0.01^{a}$ & $0.076 \pm 0.04^{a}$ & 0.000 \\
\hline G3 & $0.061 \pm 0.02^{a}$ & $0.414 \pm 0.09^{b}$ & 0.436 \\
\hline G4 & $0.059 \pm 0.01^{a}$ & $0.061 \pm 0.01^{a}$ & 0.215 \\
\hline G5 & $0.063 \pm 0.01^{a}$ & $0.075 \pm 0.01^{a}$ & \\
\hline \hline
\end{tabular}

Letras iguais nas linhas indicam que os grupos são estatisticamente semelhantes $(p<0,05)$.

Tabela 6 - Médias e desvios padrão (DP) utilizados na comparação intragrupos da microdureza superficial dos espécimes antes (T0) e depois (T1) das aplicações dos produtos testados (Teste t pareado).

\begin{tabular}{|c|c|c|c|}
\hline Grupos & Microdureza T0 & Microdureza T1 & $\mathbf{p}$ \\
\hline \multicolumn{4}{|c|}{ Média \pm DP } \\
\hline G1 & $16.27 \pm 0.54^{a}$ & $15.72 \pm 1,06^{a}$ & 0,388 \\
\hline G2 & $15.86 \pm 0.88^{a}$ & $15.40 \pm 0.63^{a}$ & 0.700 \\
\hline G3 & $16.05 \pm 1.02^{a}$ & $35.54 \pm 14.55^{b}$ & 0.000 \\
\hline G4 & $15.79 \pm 0.58^{a}$ & $16.00 \pm 0.59^{a}$ & 0.181 \\
\hline G5 & $16.12 \pm 0.79^{a}$ & $16.45 \pm 0.53^{a}$ & 0.386 \\
\hline
\end{tabular}

Letras iguais nas linhas indicam que os grupos são estatisticamente semelhantes $(p<0,05)$. 
Os resultados das tabelas 5 e 6 demonstraram que no G3, cujos espécimes foram imersos em extrato alcoólico de própolis a $20 \%$, houve elevado aumento na rugosidade e na microdureza em $\mathrm{T} 1$, os quais diferiram estatisticamente dos valores em relação a T0 $(p<0,05)$.

Tabela 7 - Médias e desvios padrão (DP) utilizados na análise de variância (ANOVA) para comparar a rugosidade e a microdureza dos espécimes no primeiro dia de avaliação (T0).

\begin{tabular}{|c|c|c|c|c|c|c|}
\hline Grupos & G1 & G2 & G3 & G4 & G5 & $\mathbf{p}$ \\
\hline \multicolumn{7}{|c|}{ Média \pm DP } \\
\hline Rugosidade & $0.089 \pm 0.05$ & $0.056 \pm 0.05$ & $0.061 \pm 0.02$ & $0.059 \pm 0.01$ & $0.063 \pm 0.01$ & 0.113 \\
\hline Microdureza & $16.27 \pm 0.54$ & $15.86 \pm 0.88$ & $16.05 \pm 1.02$ & $15.79 \pm 0.58$ & $16.12 \pm 0.79$ & 0.655 \\
\hline
\end{tabular}

Tabela 8 - Médias e desvios padrão utilizados na análise (ANOVA) e Teste de Tukey para comparar a rugosidade e a microdureza dos espécimes no décimo quarto dia de avaliação (T1).

\begin{tabular}{|c|c|c|c|c|c|c|}
\hline Grupos & G1 & G2 & G3 & G4 & G5 & $\mathbf{p}$ \\
\hline \multicolumn{7}{|c|}{ Média (DP) } \\
\hline Rugosidade & $0.069 \pm 0.02^{a}$ & $0.076 \pm 0.04^{a}$ & $0.414 \pm 0.09^{b}$ & $0.061 \pm 0.01^{a}$ & $0.075 \pm 0.01^{a}$ & 0.000 \\
\hline Microdureza & $16.45 \pm 0.53^{a}$ & $16.00 \pm 0.59^{a}$ & $16.05 \pm 2.02^{b}$ & $15.40 \pm 0.63^{a}$ & $15.72 \pm 1.06^{a}$ & 0.000 \\
\hline
\end{tabular}

Letras iguais nas linhas indicam que os grupos são estatisticamente semelhantes $(p<0,05)$. 
Ao analisar as tabelas 7 e 8 , verificou-se não haver diferenças estatísticas significantes $(p>0,05)$ entre os grupos analisados, no primeiro tempo de avaliação, em ambas as propriedades superficias analisadas.

Porém, no tocante ao segundo tempo de avaliação (T1), observou-se que apenas o grupo G3 diferiu significantemente dos demais grupos avaliados $(p<0,05)$, apresentando os maiores valores de rugosidade e de microdureza superficial. 
3(d)PAULO MAURICIO R

AGUA DESTILADA

DS:EXTERNO

क: $10 / 00 / 11$

\section{Discussão}





\section{DISCUSSÃO}

O presente estudo teve como propósito analisar, de forma mais abrangente e inédita, o efeito de produtos naturais no tratamento da EP. Para isso, diferentemente de estudos anteriores realizados apenas in vitro, nesta pesquisa foi realizado um ensaio clínico e duas análises laboratoriais, visando observar o efeito dessas drogas em células tanto na forma planctônica quanto em biofilmes, estrutura na qual os micro-organismos se encontram agregados e com avantajada resistência aos agentes antimicrobianos, e na superfície resinosa, onde estes micro-organimos se aderem e, em seguida, desenvolvem a EP.

Para isto, três drogas naturais foram selecionadas: o extrato alcoólico de própolis a $20 \%$, o gel de $P$. granatum Linné e o gel de $U$. tomentosa. A seleção destas substâncias foi baseada na literatura, em estudos clínicos e laboratoriais, os quais comprovaram previamente a eficácia antimicrobiana das mesmas. Outros biofármacos em evidência na literatura corrente, como a Melaleuca alternifólia, não foram utilizados neste estudo, visto que não são plantas nativas brasileiras e tampouco cultivadas em nosso país, tornando difícil a obtenção de seus extratos no mercado.

Nos últimos anos, pesquisas sobre estes e outros medicamentos naturais têm aumentado devido à crescente resistência microbiana aos medicamentos alopáticos disponíveis no comércio e aos efeitos indesejávies produzidos por estas drogas, como náuseas, enjoos e reações alérgicas. Desta forma, esforços têm sido concentrados na busca de compostos naturais que apresentem baixa toxicidade, mínimo efeito colateral e, sobretudo, possam ser utilizados como substitutos dos princípios ativos sintéticos de fármacos antibióticos e antifúngicos no combate às doenças infecciosas, como a EP. 


\subsection{Da metodologia}

Em relação à metodologia aplicada, alguns aspectos merecem ser esclarecidos em cada análise deste estudo.

A fim de se evitar perda da amostra por faltas dos participantes às avaliações, quer seja por dificuldade de transporte ou por problemas financeiros, este estudo foi desenvolvido em abrigos de idosos, ou seja, o pesquisador foi ao encontro dos pacientes e não o contrário.

Mesmo assim, durante a realização deste estudo, outros fatores dificultaram a obtenção da amostra. Entre os quais, destacam-se os critérios adotados para seleção da amostra, em especial, a exclusão de pacientes por uso de medicamentos para diabetes ou hipertensão, uma vez que a maioria dos residentes dos abrigos é formada por idosos, os quais geralmente apresentam alterações endócrinas ou cardíacas, com necessidade do uso crônico desses medicamentos no controle destas enfermidades. Assim, como estas doenças e estes medicamentos podem interferir diretamente na EP, grande parte dos residentes dos abrigos não pode fazer parte desta pesquisa. Somado a isso, como a EP é uma patologia assintomática e quase oculta na cavidade bucal, muitos pacientes não acreditaram no tratamento e não se interessaram em participar da pesquisa.

Nesta avaliação, foi utilizado o parâmetro micológico de contagem de UFC/mL de fungos do gênero Candida. Estudos relatam que $93 \%$ dos indivíduos com EP apresentam infecção por Candida spp.. (BUDTZ-JORGENSEN, 1990), portanto, a presença destes micro-organismos, associada aos sinais e sintomas clínicos, pode ser considerada satisfatória para o estabelecimento do diagnóstico e como critério para a avaliação da efetividade do tratamento da patologia em questão. Vale ressaltar que este mesmo parâmetro micológico também foi utilizado como critério para a avaliação da eficácia dos produtos naturais sobre a quantidade de Candida spp. na superfície interna das próteses. Assim, este trabalho se diferenciou de outros estudos, nos quais o efeito antimicrobiano dessas drogas foi apenas analisado na mucosa palatal de pacientes com EP.

Não foram realizados registros fotográficos intrabucais da região da mucosa palatina para avaliação da efetividade dos produtos naturais no tratamento da EP, pois foi encontrada, durante testes-piloto, muita dificuldade pelos pacientes em realizar uma abertura bucal que pudesse ser compatível com a colocação de 
afastadores labiais e do espelho intrabucal, os quais são necessários para a padronização das tomadas fotográficas.

Estudos a respeito da efetividade de antifúngicos sobre a EP têm sido realizados com diferentes tempos de tratamento (VASCONCELOS et al., 2003; SANTOS et al., 2005; PAIVA et al., 2008; SANTOS et al., 2008). Em nosso estudo, a fim de que houvesse padronização no período de uso dos medicamentos, foi estabelecido o período de 14 dias, o qual corresponde ao período de utilização da nistatina, droga padrão-ouro no tratamento da EP.

Já para a padronização da aplicação na mucosa palatina e na superfíce interna prótese das drogas deste estudo, não foi seguida a forma de emprego da nistatina, por meio de bochecho, pois a $U$. tomentosa e $P$. granatum linne foram utilizadas na forma de gel e, por consequência, não apresentavam fluidez. Assim, os pacientes foram orientados a utilizar todos os medicamentos de maneira semelhante, através da aplicação com cotonetes nas áreas recomendadas.

Nesta linha, embora a correta orientação quanto ao uso de próteses removíveis seja a remoção das mesmas quando o paciente for dormir, para que a saliva possa exercer de forma adequada a ação antimicrobiana e de limpeza mecânica, em nosso estudo, foi diuturnamente recomendada a utilização desse aparelho protético. Assim, conseguiu-se a padronização do uso das próteses totais, uma vez que a maioria dos pacientes selecionados foi extremamente contrária à retirada da prótese antes de dormir.

Tradiocionalmente, o método de cultura microbiológica, por meio da contagem de UFC/mL em placa de Petri, tem sido o mais utilizado na análise do efeito de agentes antimicrobianos sobre a viabilidade de células microbianas em biofilmes. Para a realização deste procedimento, há a necessidade prévia da remoção das células dos biofilmes sobre o substrato, a qual pode ser realizada através de ultrassom. Em seguida, ocorre o maior incoviniente desta técnica, pois os micro-organismos extraídos dos biofilmes, após o contato com as substâncias antimicrobianas, podem perder a capacidade de formação de colônias em placa de ágar, continuando, no entanto, a exibir significativa atividade metabólica em estado de latência. Assim, ao subestimar as populações microbianas expostas a essas substâncias, o potencial antimicrobiano das drogas testadas acaba sendo erradamente superestimado (STEWART et al., 1994). 
A partir destas constatações, nesta pesquisa, o efeito antifúngico dos produtos naturais sobre células fúngicas em biofilmes foi verificado por meio de microscopia confocal de fluorescência a laser, a qual foi de capaz de julgar a viabilidade das células fúngicas em biofilmes sobre espécimes de resina acrílica, sem levar em consideração o seu crescimento em cultura.

Embora o biofilme sobre dentaduras seja formado por inúmeros microorganismos (NIKAWA, HAMADA e YAMAMOTO, 1998), avaliamos apenas o efeito dos produtos naturais sobre biofilmes compostos por $C$. albicans, os quais são os micro-organimos que mais comumente contaminam estas próteses, assim como são considerados, pela maioria dos autores, o principal agente etiológico da EP (ARENDORF e WALKER, 1987; NIKAWA, HAMADA e YAMAMOTO, 1998).

A utilização de espécime em resina acrílica termopolimerizável transparente e com de dimensões reduzidas ( $5 \times 5 \times 1 \mathrm{~mm}$ ) ocorreu a fim de possibilitar a análise do efeito dos produtos naturais sobre $C$. albicans em biofilmes sobre resina acrílica através do microscópio confocal. Durante esta análise, os espécimes foram adaptados a uma lamínula de vidro, limitando, assim, a largura e comprimento dos mesmos. A espessura e a transparência dos espécimes foram determinadas com o intuito de não haver a interferência na passagem do laser do microscópio confocal, e estão em consonância com trabalhos de semelhante metodologia (LAMFON et al., 2003; PEREIRA-CENCl et al., 2008),

Ainda sobre os espécime, este estudo utilizou espécime com rugosidade superficial média entre 1 e $2 \mu \mathrm{m}$ (SILVA et al., 2011), com o propósito de reproduzir rugosidade compatível com certas áreas da prótese total críticas para o polimento, como a superfície interna (PHILLIPS, 1986). Com isso, facilitou-se a adesão das C. albicans à superfície da resina acrílica. Segundo Donlan (DONLAN, 2001), bactérias, fungos e outros micro-organismos têm tendência natural de se aderir e colonizar as superfícies como mecanismo de sobrevivência. Este processo de adesão pode ser influenciado por fatores microbiológicos, físicos, químicos e relacionados ao material (BOLLEN, LAMBRECHTS e QUIRYNEN, 1997). No que tange aos fatores relacionados à resina acrílica, a rugosidade superficial tem sido largamente estudada, uma vez que ranhuras ou fendas na superfície deste material conferem proteção às células contra tensões de corte, permitindo que a adesão seja estabelecida mais facilmente, sendo, por isso, locais preferenciais para a colonização inicial. Além disso, as irregularidades da superfície contribuem para um 
aumento da área superficial disponível para a adesão (QUIRYNEN e BOLLEN, 1995).

Para a contaminação dos espécimes, optou-se pela padronização do inóculo fúngico em $1.10^{7} \mathrm{cel} / \mathrm{mL}$, uma vez que, segundo Chandra et al. (CHANDRA et al., 2001b), esta é a concentração ideal para formação dos biofilmes de C. albicans. Contudo, observa-se na literatura uma grande variação na concentração do inóculo microbiano empregado nos ensaios de desinfecção sobre resinas acrílicas, o que pode explicar divergências entre alguns resultados encontrados, pois uma concentração microbiana elevada pode favorecer uma contaminação mais intensa e extensa da superfície da resina acrílica, influenciando na ação das substâncias antimicrobianas avaliadas.

Os resultados obtidos neste estudo, através de microscopia confocal, demonstraram que o período de $24 \mathrm{~h}$ foi adequado para promover a formação do biofilme sobre os espécimes. A estipulação deste período foi determinada em estudos-piloto, onde foi observado que até este tempo os biofilmes apresentavam-se rico em células predominantemente viáveis. A partir deste tempo, um significante aumento no número de células não viáveis era observado. Assim, assegurou-se que os efeitos dos medicamentos não foram superestimados pela morte celular por deficiência de nutrientes. Além disso, neste período houve a formação de biofilmes pouco espessos (10 a $30 \mu \mathrm{m})$, o que assegurou a total difusão dos fluorocromos pelo biofilme e, principalmente, permitiu, após a aquisição das imagens no microscópio confocal, a contagem dos micro-organismos sobre a superfície da resina acrílica de forma individual através do programa ImageJ.

Como todo estudo in vitro, o presente trabalho também apresentou limitações, sendo que a principal delas foi a ausência do fluxo salivar, importante no controle do acúmulo de placa microbiana. Assim, a fim de minimizar essa limitação, os espécime foram mantidos sob agitação constante durante todo o período em que permaneceram nos poços das placas sob cultura. Desta forma, evitou-se o acúmulo das células fúngicas nos espécime por deposição e não por aderência. Além disso, de acordo com Thein, Samaranayake e Samaranayake (THEIN, SAMARANAYAKE e SAMARANAYAKE, 2007), há uma maior formação de biofilme de C. albicans em ambiente dinâmico do que em meio estático.

Uma vez que as drogas usadas neste estudo não são para desinfecção de próteses totais por meio de imersão, mas sim para serem aplicadas na mucosa 
palatal afetadas por EP, foi necessária a estipulação de um tempo de contato que estes produtos ficam em contato com os biofilmes sobre as próteses totais.

Assim, levando-se em consideração que, depois da aplicação destas substâncias na mucosa palatal e da instalação da prótese total, existe um tempo de contato reduzido entre estas e os biofilmes devido à ação da saliva, estudos pilotos por meio de microscopia confocal foram realizados, a fim de se determinar o tempo necessário que a nistatina (droga-padrão para o tratamento da EP) promove a perda total da viabilidade das células dos biofilmes sobre os espécimes.

Como resultado, foi observado que a nistatina após 1 min já promoveu a total morte das células dos biofilmes presentes sobre os espécimes de resina acrítica. Desta forma, para efeito de comparação, $1 \mathrm{~min}$ foi adotado como o tempo de aplicação de todas as substâncias sobre os biofilmes presentes nos espécimes de resina acrílica.

A literatura tem demonstrado frequentemente a utilização do fluorocromo FUN-1 com esse propósito (MILLARD et al., 1997; CHANDRA et al., 2001a; KUHN et al., 2002). Através deste, as células fúngicas metabolicamente não ativas (não viáveis) emitem uma coloração fluorescente difusa verde-amarelada, enquanto que nas células metabolicamente ativas (viáveis), o FUN-1 é convertido em estruturas cilíndricas intravacuolares de coloração laranja-avermelhada, fazendo com que estas células emitam esta mesma coloração (MILLARD et al., 1997). Entretanto, o FUN-1 pode provocar a formação de múltiplas estruturas cilíndricas intravacuolares nas células metabolicamente ativas na forma de hifas, possibilitando a superestimação do número de células viáveis quando a densidade celular é elevada no biofilme. Deste modo, o FUN-1 não é ideal para a avaliação da viabilidade celular de biofilmes fúngicos (JIN et al., 2005).

Portanto, o presente estudo optou pela análise do efeito dos produtos naturais na viabilidade de $C$. albicans nos biofilmes através dos fluorocromos SYTO9 e iodeto de propídeo no microscópio confocal. Esta técnica ofereceu como vantagem ser um processo rápido (completa-se em menos de $20 \mathrm{~min}$ ), quando comparado com os tradicionais testes de cultura celular em placa, pois estes geralmente requerem, no mínimo, $24 \mathrm{~h}$ de incubação. Além disso, esses fluorocromos determinam a viabilidade celular pela integridade da membrana citoplasmática celular (JIN et al., 2005), e não pelo seu estado metabólico ou crescimento, tornando, assim, essa determinação mais precisa. Segundo JIN et al. 
(JIN et al., 2005), quando usado isoladamente, o fluorocromo SYTO-9 penetra tanto em células viáveis, quanto em não viáveis, pigmentando-as de verde. Em contraste, o iodeto de propídeo penetra somente em micro-organismos não viáveis, com membrana comprometida, tornando-os vermelhos. Uma vez utilizados simultaneamente em micro-organismos não viáveis, ambos os fluorocromos penetrarão, porém quem determinará a cor destes será o iodeto de propídeo, pois o mesmo tem a capacidade de reduzir a coloração verde oferecida pelo SYTO-9, proporcionando-Ihes uma coloração avermelhada.

No presente estudo, este comportamento foi confirmado em todos os grupos analisados, onde a imagem adquirida para a identificação do SYTO-9 demonstrou as células viáveis em verde, enquanto a imagem adquirida para a identificação do iodeto de propídeo demonstrou as células não viáveis em vermelho (Figuras 2A-B, $3 A-B, 4 A-B$ e $6 A-B)$.

A seleção de uma droga antimicrobiana, a ser utilizada no tratamento da EP, não deve ser exclusivamente baseada na sua capacidade biocida. Outros aspectos devem ser levados em consideração, entre os quais se destacam os efeitos desta substância sobre a superfície resinosa das próteses removíveis.

Alterações na superfície deste tipo de prótese, sobretudo, aumento na rugosidade e diminuição da dureza, podem prejudicar a eficácia dos próprios produtos antimicrobianos aplicados na mucosa palatina acometida por EP. Estas alterações proporcionam o surgimento de um maior número de ranhuras na referida superfície, as quais servirão de abrigo e de depósito de micro-organismos e, por consequência, facilitarão a recorrência desta patologia (RAHAL et al., 2004).

Vários estudos (VASCONCELOS et al., 2003; SANTOS et al., 2005; PAIVA et al., 2008; SANTOS et al., 2008) relatam que para apresentar eficácia antifúngica, durante o tratamento da EP, as drogas utilizadas nesta pesquisa devem ser aplicadas 3 vezes na mucosa palatina, e, como resultado, também na superfíce interna da prótese. Porém, neste ensaio in vitro, optou-se pela imersão dos espécimes de resina acrílica por $24 \mathrm{~h}$, de forma initerrupta, nestas substâncias, a fim de se obter uma padronização e posterior confrontação dos dados obtidos. 


\subsection{Dos resultados}

Neste estudo, os produtos naturais testados foram eficazes no tratamento da infecção fúngica na mucosa paltina, utilizados três vezes ao dia, durante 14 dias. Estes produtos promoveram significativa inibição do crescimento fúngico nesta área, com significante redução dos valores de UFC/ml em T1, em todos os grupos, quando comparados com T0 $(p<0,05)$.

Corroborando com estes achados, outros ensaios laboratoriais (KOO et al., 2000a; KOO et al., 2000b; BRAGA et al., 2005; VASCONCELOS et al., 2006; CCAHUANA-VASQUEZ et al., 2007; SILVA et al., 2008; AL-ZOREKY, 2009; CHOI et al., 2011; SOUZA JÙNIOR et al., 2011) demonstraram a eficácia antimicrobiana dos produtos naturais testados neste estudo. Além disso, estudos clínicos prévios (OTA et al., 2001; VASCONCELOS et al., 2003; SANTOS et al., 2005; PAIVA et al., 2008; SANTOS et al., 2008) também estão de acordo com nossos resultados. Nestes estudos, as mesmas substâncias naturais testadas no presente estudo também foram efetivas no tratamento tópico da EP, em períodos que variaram de 7 a 14 dias, havendo redução da contaminação fúngica e regressão das lesões eritematosas em todos os pacientes tratados.

Os produtos naturais apresentam na sua composição princípios bioativos, os quais Ihes conferem notável efeito antimicrobiano, anti-inflamatório, antioxidante e propriedades imunomoduladoreas. Entre os compostos, destacam-se os alcalóides oxindólicos e indólicos, os taninos e os flavonóides, os quais estão em abundância na composição química da $U$. tomentosa, da $P$. granatum Linné e da Própolis, respectivamente (MARCUCCI, 1996; VASCONCELOS et al., 2003; HEITZMAN et al., 2005; CCAHUANA-VASQUEZ et al., 2007; PAIVA et al., 2008).

Apesar de o grupo controle ter apresentado os maiores valores de UFC/mL após 14 dias de tratamento da EP (T1), não houve diferença estatística entre este e os demais grupos avaliados. Assim, há de se considerar o efeito da escovação com escova dental e dentifrício da mucosa palatina no tratamento desta infecção.

Considerando o caráter recidivante das infecções fúngicas após o término dos tratamentos antifúngicos (BARBEAU et al., 2003), o presente estudo realizou uma avaliação 30 dias (T2) após a suspensão do uso da medicação, com apenas a execução pelos pacientes da higiene da mucosa palatina com escova dental e dentifrício. Como resultado, para todos os grupos, foi observado um ligeiro aumento 
na contagem de UFC/mL em todos os grupos avaliados, exceto para o grupo tratado com o extrato de $P$. granatum Linné, o qual manteve a inibição no crescimento fúngico. Nesta avaliação, apesar do grupo controle ter apresentado, mais uma vez, os maiores valores de UFC/mL, não houve diferença entre este e os demais grupos testados. Tal achado confirma a importância da higiene, por meio de escova dental e de dentifrício, da mucosa palatina durante o tratamento da EP. Nesta linha, considerando os resultados do estudo de Da Silva, et al. (DA SILVA et al., 2011), o qual demonstrou, por meio de cromatografia líquida de alta performance e de MEV, que a resina acrílica não absorve ou libera agentes antifúngicos durante 14 dias de avaliação, a ação após a suspensão dos medicamentos se deve, de fato, à escovação e ao dentifrício. Ainda, no estudo de Paraskevas et al. (PARASKEVAS et al., 2007), foi observado que a escovação manual sem dentifrício promoveu maior redução de placa microbiana do que quando associado a este produto. Assim, estes autores concluíram que o uso a escovação manual é o principal fator no processo de redução de placa microbiana, a qual é um dos fatores etiológicos para a EP.

O efeito da higiene bucal, sobretudo da escovação manual, possivelmente foi potencializado pela ação do extrato de $P$. granatum Linné, pois este grupo foi o único que manteve a redução no crescimento fúngico em T2.

Apesar de não ter sido objetivo deste estudo, a eficácia dos produtos naturais também foi observada por meio da análise visual das áreas eritematosas das mucosas palatinas, as quais se apresentaram mais claras ou imperceptíveis em T1 na maioria dos pacientes, com a manutenção deste quadro em T2. Além disso, dos 30 pacientes da amostra, apenas 1, o qual foi tratado com nistatina, relatou enjôo durante os 14 dias de tratamento.

Na superfície interna das próteses, já na avaliação incial (T0), foi constatado poucas células fúngicas em todos os grupos, o que comprometeu a comparação com as demais avaliações. Os reduzidos valores iniciais de UFC/mL podem estar associados, principalmente, ao método de coleta do material da superfície interna da prótese. De fato, a coleta da placa microbiana da prótese, por meio de espátula metálica, visivelmente removeu um reduzido volume deste material. A coleta deste material por meio de ultrassom não foi realizada, pois este procedimento seria muito demorado para os idosos, além de não haver este equipamento nos abrigos.

Consequentemente, apesar da redução no número de UFC/mL nas demais avaliações, não houve diferenças estatísticas entre os tempos de avaliação, assim 
como entre os diferentes grupos em cada tempo analisado. Cabe ressaltar que a mínima redução no número de UFC/mL observada em todos os grupos, pode ser também explicada pela higiene da prótese por meio de escova dental e de dentifrício, uma vez que os valores em T2, 30 dias após a suspensão do uso dos medicamentos, foram semelhantes aos encontrados em T1. Corrobarorando com estes achados, Lee et al. (LEE et al., 2011), verificou que a escovação com escova dental, sem a associação com outro agente limpador ou antimicrobiano, foi totalemente competente na eliminação de $C$. albicans de espécimes de resina acrílica usadas em base protéticas.

A análise através do microscópio confocal demonstrou que todos os grupos experimentais apresentaram elevada eficácia antifúngica. Os resultados demonstraram ausência células fúngicas viáveis remanescentes nos biofilmes em todos os grupos experimentais, com exceção do grupo G5, no qual foi identificado um reduzido número destas células após ação do gel de $U$. tomentosa. Porém, a análise estatística não demonstrou diferenças em relação ao número de células viáveis entre este e os demais grupos experimentais.

Ratificando a eficácia antifúngica de todos os grupos experimentais, foi observado um número elevado de células não viáveis nos biofilmes nos grupos G2, G3 e G5, não havendo diferença estatística entre os mesmos. Para os biofilmes tratados com o gel de $P$. granatum Linné, notou-se significante redução do número de células não viáveis em relação aos grupos G2 e G3, no entanto, sem diferença estatística em relação ao grupo G5.

Nos estudos de Chandra et al. (CHANDRA et al., 2001a; CHANDRA et al., 2001b), as células fúngicas exibiram, in vitro, níveis de resistência fenotípica aos agentes antifúngicos, entre eles a nistatina, quando se encontraram em biofilmes. A organização do biofilme tem sido relatada como uma forma de resistência aos agentes antimicrobianos, através de mecanismos, tais como: diminuição na taxa de crescimento e limitação de nutrientes e expressão de genes de resistência às drogas. Apesar dessas teorias, muito pouco ainda é sabido a respeito da eficácia de substâncias antimicrobianas na inativação de fungos, como C. albicans, em biofilmes. Em nosso estudo, a não resistência demonstrada pelas células fúngicas à nistatina pode ser justificada pelo uso da nistatina em maior concentração quando comparados aos estudos supracitados. Segundo Dolan (DONLAN, 2001), a quantidade e a idade do biofilme influenciam diretamente na resistência dos 
microrganismos às substâncias antimicrobianas. Sob esta premissa, a quantidade de células formadas nos biofilmes após $24 \mathrm{~h}$ pode não ter sido capaz de suportar a ação da nistatina e dos produtos naturais testados neste estudo, com exceção do grupo tratado com o gel de $U$. tomantosa, o qual apresentou poucas células viáveis remanescentes após o emprego desta droga (Figuras 6A-B).

Embora haja diferença na metodologia quando comparado ao presente estudo, sobretudo, na composição química da U. tomentosa utilizada, CcahuanaVasquez et al. (CCAHUANA-VASQUEZ et al., 2007) também observaram que esta substância não apresentou efeito inibitório sobre cepas de $C$. albicans isoladas de cavidades bucais humanas. A maior ineficácia antifúngica da U. tomentosa observada no estudo de Ccahuana-Vasquez et al. pode ser justificada pelo uso deste produto na forma micropulverizada e não de extrato, como empregado no Imuno-Max Gel.

Ainda na tabela 4, os resultados para os espécimes tratados com nistatina, extrato alcoólico própolis a $20 \%$ e gel de $U$. tomentosa demonstraram que não houve siginificativo decréscimo no número total de células do biofilme sobre a resina após o contato contato com estas substâncias, quando comparado ao grupo controle (Figuras 2A-B, 3A-B, 4A-B e 6A-B).

Não há relatos na literatura que possam ser comparados a este estudo, e, desta forma, esclatecer a ausência de removedor de biofilmes do extrato alcoólico própolis a $20 \%$ e do gel de $U$. tomentosa.

Egusa et al. (EGUSA et al., 2000) observaram resultados divergentes em relação ao do nosso estudo, no tocante ao efeito da nistatina na adesão de microorganismos. Estes autores expuseram isolados de Candida spp. à concentrações subterapêuticas de nistatina e anfotericina $B$, com o propósito de verificar o efeito na adesão microbiana à superfície de resina acrílica. Os resultados demonstraram que a exposição à concentração menor desses antifúngicos foi capaz de diminuir a adesão inicial dos micro-organismos. Esta diferença de comportamento da nistatina possivelmente foi influenciada pelo longo tempo de exposição dos micro-organimso à esta droga, o qual foi de $30 \mathrm{~min}$. Como no presente estudo o período de exposição à nistatina foi de apenas 1 minuto, este reduzido tempo pode ter sido suficiente para promover a inviabilização celular, porém insatisfatório para que houvesse alguma influência na adesão dos micro-organismos à resina. 
Por outro lado, o gel de $P$. granatum Linné demonstrou grande capacidade removedora sobre biofilmes formados na superfície da resina acrílica quando comparada aos demais grupos. Através das figuras $5 \mathrm{~A}-\mathrm{B}$, demonstrou-se que esta substância exibiu grande poder de eliminação do biofilme sobre a resina, eliminando mais de $90 \%$ do biofilme, sendo esta propriedade um dos fatores fundamentais na determinação da eficácia de um produto antimicrobiano (NIKAWA et al., 1999). Um biofilme residual, composto por células mortas, pode ainda atuar como uma fonte de endotoxinas, permitindo a sua rápida recolonização e provendo proteção para novos patógenos (MEILLER et al., 1999; CHEN e STEWART, 2000; LIAQAT e SABRI, 2008).

Corroborando com estes achados, Vasconcelos et al. (VASCONCELOS et al., 2006) se propuseram a determinar o efeito antimicrobiano do gel de $P$. granatum Linné e do miconazol (Daktarin® gel oral) na adesão ao vidro de 3 cepas padrão de Streptococos (mutans, sangui, e mitis), do $S$. mutans isoladas clinicamente (IC) e da C. albicans com e sem associações. Segundo estes autores, o gel de P. granatum Linné demonstrou maior eficiência em inibir a adesão microbiana do que 0 miconazol. Ainda, Schreiner et al. (SCHREINER et al., 2009) avaliaram a ação antimicrobiana do chá de romã na inibição da adesão de micro-organismos oriundos da saliva sobre ligaduras ortodônticas elásticas. Como resultado, foi verificado que, com o uso do chá de romã, a média de $U F C / m L$ recuperada de ligaduras ortodônticas foi significativamente inferior ao controle negativo, mas superior a da clorexidina. Os resultados destes dois estudos sugerem que o fitofámaco em questão pode ser usado no controle da adesão de diferentes micro-organismos na cavidade bucal.

De acordo com os dados das tabelas 5, 6, 7 e 8 é possível verificar que a rugosidade e a dureza não sofreram alterações estatisticamente significantes durante o período analisado em todos os grupos analisados, exceto no G3, onde os espécimes foram imersos no extrato alcoólico de própolis a 20\%. Nesse grupo, foi observado um aumento significante nos valores de rugosidade e dureza superficiais após 14 dias de imersão.

A literatura é extremamente escassa no que diz respeito aos efeitos de drogas naturais ou alopáticas sobre resinas acrílicas. Em um dos poucos estudos existentes, o qual corrabora com os achados desta pesquisa, Da Silva et al. (DA SILVA et al., 2008) demonstraram as mesmas alterações na rugosidade de dureza 
de resinas acrílicas promovidas pelo gel orabase de extrato etanólico de própolis a $20 \%$, após 14 dias de imersão. Segundo estes autores a deposição e o acúmulo da própolis sobre a superfície resinosa foram os responsáveis por esses efeitos neste material. Ainda, Regis et al. (REGIS et al., 2009) relatam que o álcool, substância que compõe $80 \%$ do extrato alcoólico de própolis a $20 \%$, provocou aumento na rugosidade e diminuição na dureza de espécimes polimerizados por micro-ondas quando presente em concentrações maiores do que $42 \%$.

De posse dessas informações, presume-se que a própolis, uma vez depositada na superfície resinosa, não acarretaria amolecimento da camada superficial, mas desintegraria esta superfície, gerando imperfeições ou ranhuras. A própolis conseguiria interagir mais facilmente na matriz polimérica das resinas acrílicas, uma vez que possui também origem resinosa. Vale ressaltar que este quadro pode ser agravado clinicamente, pois a escovação, realizada durante a higiene da prótese, favorece ainda mais o aumento na rugosidade superficial.

Em outra pesquisa, Al-Dwairi, Al-Quran e Al-Omari (AL-DWAIRI, AL-QURAN e AL-OMARI, 2012) observaram que, após 14 dias de imersão, a nistatina não alterou a dureza superficial, mas exarcebou a rugosidade superficial. As diferenças nos resultados encontradas por estes autores podem ser explicadas pelo fato que, após 14 dias, os espécimes imersos em nistatina foram comparados com os do grupo controle, os quais foram armazenados a seco.

Em linhas gerais, os resultados obtidos pela cultura microbiológica, pelo microscópio confocal e pela análise da superfíe resinosa, demonstraram que o gel de $P$. granatum Linné apresentou propriedades superiores em relação aos produtos natrais testados. Em nosso estudo, esta substância manifestou um efeito mais completo, uma vez que, associada à escovação manual, proporcionou a maior redução da contaminação fúngica da mucosa palatina de pacientes com EP em longo prazo (T2), promoveu, in vitro, supressão total da viabilidade e maior remoção das células fúngicas em biofilmes e não alterou, in vitro, a rugosidade e a dureza da resina acrílica.

Todavia, considerando o baixo custo e os incomuns efeitos colaterias dos produtos naturais junto ao aumento da resistência microbiana frente aos medicamentos alopáticos, mais estudos devem ser realizados, com intuito de que haja o desenvolvimento de novos biofármacos de elevada eficácia na terapêutica das infecções fúngicas e bacterianas. 
Neste contexto, futuras pesquisas clínicas, utilizando uma metodologia com similitude ao nosso estudo, porém com maior número de pacientes, devem ser realizadas, a fim de esclarecer se os nossos achados estão relacionados à ação dos produtos naturais, ao tamanho reduzido da amostra, ou à higiene bucal e da prótese.

Já para futuros estudos in vitro, a respeito do efeito de produtos naturais sobre biofilmes, seria interessante ampliá-los a um leque mais variado de espécies de fungos e de substâncias testadas, dado que com o uso generalizado dos antifúngicos, observa-se o surgimento de novas espécies de micro-organismos cada vez mais resistentes. Ademais, nestes estudos deveriam ser desenvolvidos biofilmes em condições padronizadas e mais próximas da realidade por meio de equipamentos, como o CDFF (Constant Depth Film Fermentar) (LAMFON et al., 2005), o qual regula condições de crescimento do biofilme, como a temperatura e o $\mathrm{pH}$, ou atarvés de dispositivos de acrílico, o qual promovem a formação de biofilmes de modo intra-bucal. Também, poderia ser realizada uma análise da efetividade das substâncias naturais durante as várias fases de desenvolvimento de um biofilme, o que poderia permitir uma avaliação mais precisa sobre qual, ou quais os possíveis mecanismos de resistência que o biofilme poderia apresentar.

Por fim, outros estudos devem ser realizados, a fim de se verificar os efeitos dos produtos naturais utilizados neste experimento, em longo prazo, sobre outras propriedades da resina acrílica, sobretudo, relacionadas à adesão de microorganimos, como a energia livre de superfície. Assim, poderíamos obter novas informações a reseito da eliminação de biofilmes sobre a superfície resinosa e, por conseguinte, comparar com os resultados obtidos por meio de microscopia confocal deste estudo. 
(3)(a)PAULO MAURICIO R AGUA DESTILADA

D: EXTERNO

fo: 10/08/11

(a)PAULO MAURICIO Ro

ITURA DE PROPOLIS 20

So:INTERNO

[0.10/00/11

6 Conclusão 



\section{CONCLUSÃO}

De acordo com os resultados obtidos neste estudo, foi possível concluir que:

- $\quad$ O gel de $P$. granatum Linné apresentou propriedades superiores em relação aos produtos natrais testados. Esta substância apresentou um efeito mais completo, uma vez que, associada à escovação manual, proporcionou a maior redução da contaminação fúngica da mucosa palatina de pacientes com EP em longo prazo, promoveu, in vitro, perda total da viabilidade e maior remoção das células fúngicas em biofilmes e não alterou, in vitro, a rugosidade e a dureza da resina acrílica testada.

- Os demais produtos naturais testados, apesar de apresentarem elevada eficácia antifúngica in vitro e in vivo, apresentaram baixo poder de remoção do biofilme e, ainda, como no caso do extrato alcoólico de própolis a $20 \%$, alteraram as propriedades superficiais da resina acrílica testada. 

3(a)PAULO MAURICIO R

AGUA DESTILADA

DS:EXTERNO

क: $10 / 00 / 11$

\section{Referências}

nistatina

$100.000 \mathrm{UI}$ por done do $1 \mathrm{~m}$

Suspenslo Ora

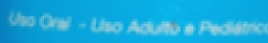

Contalos 50 mi com conth gats 



\section{REFERÊNCIAS}

Aguilar JL, Rojas P, Marcelo A, Plaza A, Bauer R, Reininger E, et al. Antiinflammatory activity of two different extracts of Uncaria tomentosa (Rubiaceae). J Ethnopharmacol. 2002 Jul;81(2):271-6.

Al-Dwairi ZN, Al-Quran FA, Al-Omari OY. The effect of antifungal agents on surface properties of poly(methyl methacrylate) and its relation to adherence of Candida albicans. J Prosthodont Res. 2012 Oct;56(4):272-80.

Al-Zoreky NS. Antimicrobial activity of pomegranate (Punica granatum L.) fruit peels. Int J Food Microbiol. 2009 Sep 15;134(3):244-8.

Alberts B. Biologia molecular da célula. 4 ed. Porto Alegre: Artmed; 2004.

Allegra F, Gennari PU. Doenças da mucosa bucal. 1 ed. São Paulo: Editora Santos; 2000.

Arendorf TM, Walker DM. Denture stomatitis: a review. J Oral Rehabil. 1987 May;14(3):217-27.

Aviram M, Dornfeld L. Pomegranate juice consumption inhibits serum angiotensin converting enzyme activity and reduces systolic blood pressure. Atherosclerosis. 2001 Sep;158(1):195-8.

Aviram M, Dornfeld L, Rosenblat M, Volkova N, Kaplan M, Coleman R, et al. Pomegranate juice consumption reduces oxidative stress, atherogenic modifications to LDL, and platelet aggregation: studies in humans and in atherosclerotic apolipoprotein E-deficient mice. Am J Clin Nutr. 2000 May;71(5):1062-76.

Barbeau J, Seguin J, Goulet JP, de Koninck L, Avon SL, Lalonde B, et al. Reassessing the presence of Candida albicans in denture-related stomatitis. Oral Surg Oral Med Oral Pathol Oral Radiol Endod. 2003 Jan;95(1):51-9.

Bergendal T, Isacsson G. Effect of nystatin in the treatment of denture stomatitis. Scand J Dent Res. 1980 Oct;88(5):446-54. 
Blomgren J, Berggren $U$, Jontell M. Fluconazole versus nystatin in the treatment of oral candidosis. Acta Odontol Scand. 1998 Aug;56(4):202-5.

Bollen CM, Lambrechts P, Quirynen M. Comparison of surface roughness of oral hard materials to the threshold surface roughness for bacterial plaque retention: a review of the literature. Dent Mater. 1997 Jul;13(4):258-69.

Bosio K, Avanzini C, D'Avolio A, Ozino O, Savoia D. In vitro activity of propolis against Streptococcus pyogenes. Lett Appl Microbiol. 2000 Aug;31(2):174-7.

Braga LC, Shupp JW, Cummings C, Jett M, Takahashi JA, Carmo LS, et al. Pomegranate extract inhibits Staphylococcus aureus growth and subsequent enterotoxin production. J Ethnopharmacol. 2005 Jan 4;96(1-2):335-9.

Brasil. Agência Nacional de Vigilância Sanitária.Resolução RDC no 132, de 29 de Maio de 2003. Diário Oficial da União, de 02 de Outubro de 2003. 2003.

Budtz-Jorgensen E. Etiology, pathogenesis, therapy, and prophylaxis of oral yeast infections. Acta Odontol Scand. 1990 Feb;48(1):61-9.

Campagnoli EB, Sandrin R, Durscki J, Grégio AMT, Lima AAS. Candidose, qual o melhor tratamento? . JBC j. bras. clin. odontol. integ. 2004 Jan-Fev;8(43):72-6.

Campanha NH, Pavarina AC, Brunetti IL, Vergani CE, Machado AL, Spolidorio DM. Candida albicans inactivation and cell membrane integrity damage by microwave irradiation. Mycoses. 2007 Mar;50(2):140-7.

Casaroto AR, Lara VS. Phytomedicines for Candida-associated denture stomatitis. Fitoterapia. $2010 \mathrm{Jul} ; 81(5): 323-8$.

Ccahuana-Vasquez RA, Santos SS, Koga-Ito CY, Jorge AO. Antimicrobial activity of Uncaria tomentosa against oral human pathogens. Braz Oral Res. 2007 JanMar;21(1):46-50.

Chandra J, Kuhn DM, Mukherjee PK, Hoyer LL, McCormick T, Ghannoum MA. Biofilm formation by the fungal pathogen Candida albicans: development, architecture, and drug resistance. J Bacteriol. 2001a Sep;183(18):5385-94. 
Chandra J, Mukherjee PK, Leidich SD, Faddoul FF, Hoyer LL, Douglas LJ, et al. Antifungal resistance of candidal biofilms formed on denture acrylic in vitro. J Dent Res. 2001b Mar;80(3):903-8.

Chen X, Stewart PS. Biofilm removal caused by chemical treatments. Wat. Res. $2000 ; 34(17): 4229-33$.

Choi JG, Kang OH, Lee YS, Chae HS, Oh YC, Brice OO, et al. In Vitro and In Vivo Antibacterial Activity of Punica granatum Peel Ethanol Extract against Salmonella. Evid Based Complement Alternat Med. 2011;2011:690518.

Coco BJ, Bagg J, Cross LJ, Jose A, Cross J, Ramage G. Mixed Candida albicans and Candida glabrata populations associated with the pathogenesis of denture stomatitis. Oral Microbiol Immunol. 2008 Oct;23(5):377-83.

Cowan MM. Plant products as antimicrobial agents. Clin Microbiol Rev. 1999 Oct;12(4):564-82.

Cumming CG, Wight C, Blackwell CL, Wray D. Denture stomatitis in the elderly. Oral Microbiol Immunol. 1990 Apr;5(2):82-5.

da Silva WJ, Gonçalves LM, Faot F, Trevizan LRP, Del Bel Cury AA. Poly (Methyl Methacrylate) absorption and releasing of nystatin and fluconazole. Archives of Oral Research. 2011;7(3):Set./Dez. .

da Silva WJ, Rached RN, Rosalen PL, Del bel Cury AA. Effects of nystatin, fluconazole and propolis on poly(methyl methacrylate) resin surface. Braz Dent J. 2008;19(3):190-6.

de Souza A, Cimerman S. Uncaria tomentosa (Cat's claw): uma potencial estratégia terapêutica para herpes labial

Rev Panam Infectol 2010;12(2):51-7.

Djipa CD, Delmee M, Quetin-Leclercq J. Antimicrobial activity of bark extracts of Syzygium jambos (L.) alston (Myrtaceae). J Ethnopharmacol. 2000 Jul;71(1-2):30713.

Donlan RM. Biofilm formation: a clinically relevant microbiological process. Clin Infect Dis. 2001 Oct 15;33(8):1387-92. 
Egusa H, Ellepola AN, Nikawa H, Hamada T, Samaranayake LP. Exposure to subtherapeutic concentrations of polyene antifungals suppresses the adherence of Candida species to denture acrylic. Chemotherapy. 2000 Jul-Aug;46(4):267-74.

Gracious Ross R, Selvasubramanian S, Jayasundar S. Immunomodulatory activity of Punica granatum in rabbits--a preliminary study. J Ethnopharmacol. 2001 Nov;78(1):85-7.

Grange JM, Davey RW. Antibacterial properties of propolis (bee glue). J R Soc Med. 1990 Mar;83(3):159-60.

Groeschke J, Solassol I, Bressolle F, Pinguet F. Stability of amphotericin B and nystatin in antifungal mouthrinses containing sodium hydrogen carbonate. J Pharm Biomed Anal. 2006 Sep 26;42(3):362-6.

Havsteen BH. The biochemistry and medical significance of the flavonoids. Pharmacol Ther. 2002 Nov-Dec;96(2-3):67-202.

Hawser SP, Douglas LJ. Biofilm formation by Candida species on the surface of catheter materials in vitro. Infect Immun. 1994 Mar;62(3):915-21.

Heitzman ME, Neto CC, Winiarz E, Vaisberg AJ, Hammond GB. Ethnobotany, phytochemistry and pharmacology of Uncaria (Rubiaceae). Phytochemistry. 2005 Jan;66(1):5-29.

Jin Y, Zhang T, Samaranayake YH, Fang HH, Yip HK, Samaranayake LP. The use of new probes and stains for improved assessment of cell viability and extracellular polymeric substances in Candida albicans biofilms. Mycopathologia. 2005 Apr;159(3):353-60.

Jurenka JS. Therapeutic applications of pomegranate (Punica granatum L.): a review. Altern Med Rev. 2008 Jun;13(2):128-44.

Koo H, Gomes BP, Rosalen PL, Ambrosano GM, Park YK, Cury JA. In vitro antimicrobial activity of propolis and Arnica montana against oral pathogens. Arch Oral Biol. 2000a Feb;45(2):141-8. 
Koo H, Rosalen PL, Cury JA, Ambrosano GM, Murata RM, Yatsuda R, et al. Effect of a new variety of Apis mellifera propolis on mutans Streptococci. Curr Microbiol. 2000b Sep;41(3):192-6.

Kubinova L, Janacek J. Confocal microscopy and stereology: estimating volume, number, surface area and length by virtual test probes applied to three-dimensional images. Microsc Res Tech. 2001 Jun 15;53(6):425-35.

Kuhn DM, Chandra J, Mukherjee PK, Ghannoum MA. Comparison of biofilms formed by Candida albicans and Candida parapsilosis on bioprosthetic surfaces. Infect Immun. 2002 Feb;70(2):878-88.

Kumamoto CA. Candida biofilms. Curr Opin Microbiol. 2002 Dec;5(6):608-11.

Lamfon H, Al-Karaawi Z, McCullough M, Porter SR, Pratten J. Composition of in vitro denture plaque biofilms and susceptibility to antifungals. FEMS Microbiol Lett. 2005 Jan 15;242(2):345-51.

Lamfon H, Porter SR, McCullough M, Pratten J. Formation of Candida albicans biofilms on non-shedding oral surfaces. Eur J Oral Sci. 2003 Dec;111(6):465-71.

Langley P. Why a pomegranate? Bmj. 2000 Nov 4;321(7269):1153-4.

Lee $\mathrm{H}-\mathrm{E}$, Li C-Y, Chang H-W, Yang Y-H, Wu J-H. Effects of different denture cleaning methods to remove Candida albicans from acrylic resin denture based material. Journal of Dental Sciences. 2011;6:216-20.

Liaqat I, Sabri AN. Effect of biocides on biofilm bacteria from dental unit water lines. Curr Microbiol. 2008 Jun;56(6):619-24.

Lu LC, Chen YW, Chou CC. Antibacterial activity of propolis against Staphylococcus aureus. Int J Food Microbiol. 2005 Jul 15;102(2):213-20.

Lu Y, Wu C, Yuan Z. Determination of hesperetin, cinnamic acid and nicotinic acid in propolis with micellar electrokinetic capillary chromatography. Fitoterapia. 2004 Jun;75(3-4):267-76.

Machado TB, Pinto AV, Pinto MC, Leal IC, Silva MG, Amaral AC, et al. In vitro activity of Brazilian medicinal plants, naturally occurring naphthoquinones and their 
analogues, against methicillin-resistant Staphylococcus aureus. Int J Antimicrob Agents. 2003 Mar;21(3):279-84.

Marcucci M. Propriedades biológicas e terapêuticas dos constituintes químicos da própolis. São Paulo: Química Nova; 1996.

Meiller TF, Depaola LG, Kelley JI, Baqui AA, Turng BF, Falkler WA. Dental unit waterlines: biofilms, disinfection and recurrence. J Am Dent Assoc. 1999 Jan;130(1):65-72.

Millard PJ, Roth BL, Thi HP, Yue ST, Haugland RP. Development of the FUN-1 family of fluorescent probes for vacuole labeling and viability testing of yeasts. Appl Environ Microbiol. 1997 Jul;63(7):2897-905.

Mima EG, Pavarina AC, Neppelenbroek KH, Vergani CE, Spolidorio DM, Machado AL. Effect of different exposure times on microwave irradiation on the disinfection of a hard chairside reline resin. J Prosthodont. 2008 Jun;17(4):312-7.

Mur E, Hartig F, Eibl G, Schirmer M. Randomized double blind trial of an extract from the pentacyclic alkaloid-chemotype of uncaria tomentosa for the treatment of rheumatoid arthritis. J Rheumatol. 2002 Apr;29(4):678-81.

Neppelenbroek KH, Pavarina AC, Palomari Spolidorio DM, Sgavioli Massucato EM, Spolidorio LC, Vergani CE. Effectiveness of microwave disinfection of complete dentures on the treatment of Candida-related denture stomatitis. J Oral Rehabil. 2008 Nov;35(11):836-46.

Neville BW. Patologia Oral e Maxilofacial. 2 ed. Rio de Janeiro: Guanabara Koogan; 2004.

Nikawa H, Hamada T, Yamamoto T. Denture plaque--past and recent concerns. J Dent. 1998 May;26(4):299-304.

Nikawa $\mathrm{H}$, Hamada $\mathrm{T}$, Yamashiro $\mathrm{H}$, Kumagai $\mathrm{H}$. A review of in vitro and in vivo methods to evaluate the efficacy of denture cleansers. Int J Prosthodont. 1999 MarApr;12(2):153-9.

Ota C, Unterkircher C, Fantinato V, Shimizu MT. Antifungal activity of propolis on different species of Candida. Mycoses. 2001 Nov;44(9-10):375-8. 
Paiva LCA, Ribeiro RA, Pereira JV, Oliveira NMC. Avaliação clínica e laboratorial do gel da Uncaria tomentosa (Unha de Gato) sobre candidose oral. Revista Brasileira de Farmacognosia. 2008 Abr - Jun;19(2A):423-8.

Paraskevas S, Rosema NA, Versteeg P, Timmerman MF, van der Velden U, van der Weijden GA. The additional effect of a dentifrice on the instant efficacy of toothbrushing: a crossover study. J Periodontol. 2007 Jun;78(6):1011-6.

Patton LL, Bonito AJ, Shugars DA. A systematic review of the effectiveness of antifungal drugs for the prevention and treatment of oropharyngeal candidiasis in HIV-positive patients. Oral Surg Oral Med Oral Pathol Oral Radiol Endod. 2001 Aug;92(2):170-9.

Pereira-Cenci T, Cury AA, Cenci MS, Rodrigues-Garcia RC. In vitro Candida colonization on acrylic resins and denture liners: influence of surface free energy, roughness, saliva, and adhering bacteria. Int J Prosthodont. 2007 MayJun;20(3):308-10.

Pereira-Cenci T, Deng DM, Kraneveld EA, Manders EM, Del Bel Cury AA, Ten Cate $\mathrm{JM}$, et al. The effect of Streptococcus mutans and Candida glabrata on Candida albicans biofilms formed on different surfaces. Arch Oral Biol. 2008 Aug;53(8):75564.

Phillips FA. Materiais dentários de Skinner. 8 ed. Rio de Janeiro: Guanabara; 1986.

Pinto LR, Acosta EJ, Tavora FF, da Silva PM, Porto VC. Effect of repeated cycles of chemical disinfection on the roughness and hardness of hard reline acrylic resins. Gerodontology. 2010 Jun;27(2):147-53.

Quirynen M, Bollen CM. The influence of surface roughness and surface-free energy on supra- and subgingival plaque formation in man. A review of the literature. J Clin Periodontol. 1995 Jan;22(1):1-14.

Rahal JS, Mesquita MF, Henriques GE, Nobilo MA. Surface roughness of acrylic resins submitted to mechanical and chemical polishing. J Oral Rehabil. 2004 Nov;31(11):1075-9.

Ramage G, Saville SP, Thomas DP, Lopez-Ribot JL. Candida biofilms: an update. Eukaryot Cell. 2005 Apr;4(4):633-8. 
Regis RR, Soriani NC, Azevedo AM, Silva-Lovato CH, Paranhos HF, de Souza RF. Effects of ethanol on the surface and bulk properties of a microwave-processed PMMA denture base resin. J Prosthodont. 2009 Aug;18(6):489-95.

Reis SR, Valente LM, Sampaio AL, Siani AC, Gandini M, Azeredo EL, et al. Immunomodulating and antiviral activities of Uncaria tomentosa on human monocytes infected with Dengue Virus-2. Int Immunopharmacol. 2008 Mar;8(3):46876.

Samet N, Laurent C, Susarla SM, Samet-Rubinsteen N. The effect of bee propolis on recurrent aphthous stomatitis: a pilot study. Clin Oral Investig. 2007 Jun;11(2):143-7.

Santos VR, Gomes RT, de Mesquita RA, de Moura MD, Franca EC, de Aguiar EG, et al. Efficacy of Brazilian propolis gel for the management of denture stomatitis: a pilot study. Phytother Res. 2008 Nov;22(11):1544-7.

Santos VR, Pimenta FJ, Aguiar MC, do Carmo MA, Naves MD, Mesquita RA. Oral candidiasis treatment with Brazilian ethanol propolis extract. Phytother Res. 2005 Jul;19(7):652-4.

Sartori EA, Schmidt CB, Walber LF, Shinkai RS. Effect of microwave disinfection on denture base adaptation and resin surface roughness. Braz Dent J. 2006;17(3):195200.

Schreiner F, Retzlaff G, Siqueira MFR, Rezende EC, Simão LC, Kozlowski-Junior VA, et al. Uso do chá de Punica granatum (Romã) no controle da aderência de bactérias orais em ligaduras ortodônticas. Robrac. 2009 Jun;18(45):56-61.

Schubert SY, Lansky EP, Neeman I. Antioxidant and eicosanoid enzyme inhibition properties of pomegranate seed oil and fermented juice flavonoids. J Ethnopharmacol. 1999 Jul;66(1):11-7.

Sforcin JM, Fernandes A, Jr., Lopes CA, Bankova V, Funari SR. Seasonal effect on Brazilian propolis antibacterial activity. J Ethnopharmacol. 2000 Nov;73(1-2):243-9.

Sforcin JM, Orsi RO, Bankova V. Effect of propolis, some isolated compounds and its source plant on antibody production. J Ethnopharmacol. 2005 Apr 26;98(3):301-5. 
Sheng $\mathrm{Y}$, Bryngelsson C, Pero RW. Enhanced DNA repair, immune function and reduced toxicity of C-MED-100, a novel aqueous extract from Uncaria tomentosa. J Ethnopharmacol. 2000 Feb;69(2):115-26.

Silva M, Higino J, Pereira J, Siqueira-Júnior J, Pereira M. Antibiotic activity of the extract of Punica granatum Linn. over bovine strains of Staphylococcus aureus. Brazilian Journal of Pharmacognosy. 2008;18(2):209-12.

Silva MM, Vergani CE, Giampaolo ET, Neppelenbroek KH, Spolidorio DM, Machado AL. Effectiveness of microwave irradiation on the disinfection of complete dentures. Int J Prosthodont. 2006 May-Jun;19(3):288-93.

Silva PM, Acosta EJ, Pinto Lde R, Graeff M, Spolidorio DM, Almeida RS, et al. Microscopical analysis of Candida albicans biofilms on heat-polymerised acrylic resin after chlorhexidine gluconate and sodium hypochlorite treatments. Mycoses. 2011 Nov;54(6):e712-7.

Simões CC, de Araújo DB, de Araújo RPC. Estudo in vitro e ex vivo da ação de diferentes concentrações de extratos de própolis frente aos microrganismos presentes na saliva de humanos. Rev. Bras. Farmacogn. 2008 Jan./Mar;18(1):84-9.

Smith K, Hunter IS. Efficacy of common hospital biocides with biofilms of multi-drug resistant clinical isolates. J Med Microbiol. 2008 Aug;57(Pt 8):966-73.

Souza Jùnior U, Pereira J, Pereira M, Costa M, Pereira A, Antunes R. Atividade antifúngica in vitro do extrato da Uncaria Tomentosa L. (unha de gato) sobre cepas do gênero Candida. Pesq Bras Odontoped Clin Integr. 2011 out./dez;11(4):477-80.

Stewart PS, Griebe T, Srinivasan R, Chen CI, Yu FP, deBeer D, et al. Comparison of respiratory activity and culturability during monochloramine disinfection of binary population biofilms. Appl Environ Microbiol. 1994 May;60(5):1690-2.

Tavares W. Manual de Antibióticos e Quimioterápicos Antiinfecciosos. 3 ed. Rio de Janeiro: Atheneu; 2001.

Thein ZM, Samaranayake YH, Samaranayake LP. In vitro biofilm formation of Candida albicans and non-albicans Candida species under dynamic and anaerobic conditions. Arch Oral Biol. 2007 Aug;52(8):761-7. 
Theraud M, Bedouin Y, Guiguen C, Gangneux JP. Efficacy of antiseptics and disinfectants on clinical and environmental yeast isolates in planktonic and biofilm conditions. J Med Microbiol. 2004 Oct;53(Pt 10):1013-8.

Vasconcelos LC, Sampaio FC, Sampaio MC, Pereira Mdo S, Higino JS, Peixoto MH. Minimum inhibitory concentration of adherence of Punica granatum Linn (pomegranate) gel against S. mutans, S. mitis and C. albicans. Braz Dent J. 2006;17(3):223-7.

Vasconcelos LC, Sampaio MC, Sampaio FC, Higino JS. Use of Punica granatum as an antifungal agent against candidosis associated with denture stomatitis. Mycoses. 2003 Jun;46(5-6):192-6.

Verpoorte R, Memelink J. Engineering secondary metabolite production in plants. Curr Opin Biotechnol. 2002 Apr;13(2):181-7.

Verpoorte R, van der Heijden R, Memelink J. Engineering the plant cell factory for secondary metabolite production. Transgenic Res. 2000;9(4-5):323-43; discussion 1.

Verran J, Maryan CJ. Retention of Candida albicans on acrylic resin and silicone of different surface topography. J Prosthet Dent. 1997 May;77(5):535-9.

Williams RJ, Spencer JP, Rice-Evans C. Flavonoids: antioxidants or signalling molecules? Free Radic Biol Med. 2004 Apr 1;36(7):838-49.

Wood SR, Kirkham J, Marsh PD, Shore RC, Nattress B, Robinson C. Architecture of intact natural human plaque biofilms studied by confocal laser scanning microscopy. J Dent Res. 2000 Jan;79(1):21-7.

Zaura-Arite E, van Marle J, ten Cate JM. Conofocal microscopy study of undisturbed and chlorhexidine-treated dental biofilm. J Dent Res. 2001 May;80(5):1436-40. 



\section{APÊNDICE A COMITÊ DE ÉTICA EM PESQUISA}

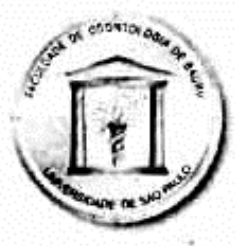

Processo $n^{2}$ 078/2010

Bauru, 27 de agosto de 2010.

\section{Universidade de São Paulo \\ Faculdade de Odontologia de Bauru .}

Al. Dr. Octávio Pinheiro Brisolla, 9-75 - Bauru-SP - CEP $17012-901$ - C.P. 73

PABX (0XX14)3235-8000-FAX (0XX14)3223-4679

Comitê de Ética em Pesquisa (14)3235-8356

mferrari@fob.usp.br

Senhor Professor,

Informamos que após o envio da documentaçăo solicitada referente ao projeto de pesquisa encaminhado a este Comitê de Ética em Pesquisa Avallaçăo clinica e laboratorial do tratamento fitoterápico sobre a estomatite protética, de autoria Paulo Mauricio Batista da Silva, sob sua orientação, foi novamente analisado e considerado APROVADO por este Colegiado, em reuniāo realizada no dia 25 de agosto de 2010.

Solicitamos que ao término do trabalho, seja enviado a este Comitê um relatório final para novo parecer, o qual será utilizado para publicação cientifica.

Atenciosamente,

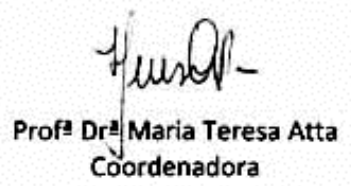

Prof. Dr. Vinicius Carvalho Porto

Docente do Departamento de Prótese 


\section{APÊNDICE B TERMO DE CONSENTIMENTO LIVRE E ESCLARECIDO}

\section{TERMO DE CONSENTIMENTO LIVRE E ESCLARECIDO}

Prezado Sr.(a), essa pesquisa tem como objetivo avaliar se os remédios à base de produtos naturais são eficazes no tratamento das infecções causadas por fungos no céu da boca sob as dentaduras, e se estes produtos trazem alguma vantagem sobre os medicamentos convencionalmente usados neste tratamento. Os remédios utilizados nesta pesquisa são medicamentos naturais, obtidos a partir de plantas medicinais e do mel de abelha, os quais são amplamente utilizados no tratamento de várias doenças e apresentam baixo efeito colateral quando comparados aos medicamentos convencionais. O tratamento das infecções causadas por fungos no céu da boca sob as dentaduras é necessário, pois, apesar de geralmente não apresentar nenhum sintoma, se esta doença se agravar, pode haver o aparecimento de coceira, queimação, inchaço, dor, sabor desagradável, mau hálito e até hemorragias na área afetada. Caso o Sr.(a) concorde, a sua infecção será tratada de forma gratuita através de um produto natural ou através de uma medicação convencional para o tratamento a estomatite. Para aqueles pacientes que receberão tratamento com produtos naturais, vale lembrar que, no final do tratamento, caso a medicação não tenha feito o efeito desejado, estes pacientes receberão tratamento através da medicação convencional. Independente da medicação prescrita, o tratamento da estomatite será avaliada em 3 períodos em todos os pacientes: antes do tratamento, após 14 dias do início do tratamento e 30 dias após o término do tratamento. Em cada avaliação, o paciente será submetido a um procedimento clínico simples, que possibilitará constatar o estado da sua infecção. Neste procedimento clínico, será passado um cotonete estéril na região do céu da boca e outro cotonete estéril na superfície interna da prótese. Todo este período de avaliação é importante, pois, deste modo, será possível observar se o medicamento prescrito foi eficaz durante este período. Essas informações serão extremamente importantes para o desenvolvimento de novos produtos, os quais possam ser aplicados no tratamento desta infecção tão freqüentemente observada nos pacientes portadores de dentaduras. Vale ressaltar que, além da medicação, o Sr.(a) ganhará uma escova dental nova e um creme dental e receberá instruções de higiene bucal. Também, fica claro que a identidade do Sr.(a) será preservada, ou seja, em nenhum momento o nome do Sr.(a) será exposto. Caso o Sr.(a) decida não participar mais da pesquisa, poderá notificar o pesquisador, sem nenhum constrangimento e será excluído da pesquisa. Se houver alguma dúvida e desejar entrar em contato com o pesquisador (Paulo Maurício Silva), os telefones para contato são: (91) 3224-2073 ou (91) 81196860.

Pelo presente instrumento que atende às exigências legais, o Sr.(a) identidade_, após leitura minuciosa das informações constantes portador da cédula de explicada pelos profissionais em seus mínimos detalhes, ciente dos serviços e procedimentos aos quais será submetido, não restando quaisquer dúvidas a respeito do lido e explicado, firma seu CONSENTIMENTO LIVRE E ESCLARECIDO concordando em participar da pesquisa proposta. 
Fica claro que o sujeito da pesquisa ou seu representante legal, pode a qualquer momento retirar seu CONSENTIMENTO LIVRE E ESCLARECIDO e deixar de participar desta pesquisa e ciente de que todas as informações prestadas tornaram-se confidenciais e guardadas por força de sigilo profissional (Art. 9o do Código de Ética Odontológica).

Por estarem de acordo assinam o presente termo.

Belém-PA, de de 


\section{APÊNDICE C FICHA CLÍNICA}

Data:

Nome:

Idade:

Data de nascimento:

Naturalidade:

Nacionalidade:

Estado Civil: Sexo:

Profissão: Fone profissional: Raça:

Endereço completo:

Cidade: Estado: Fone:

\section{QUESTIONÁRIO DE SAÚDE GERAL}

Está tomando algum medicamento? ( ) sim ( ) não

1. ( ) Hipoglicemiantes 2. ( ) Anticoncepcionais 3. ( ) Antihipertensivos

4. ( ) Insulina 5. ( ) Antialérgicos 6. ( ) Antibióticos 7. ( ) Corticóides

8. ( ) Anticoagulantes 9. ( ) Psiquiátricos 10. ( ) Analgésicos

11. ( ) Anticonvulsivantes 12. Outros 13. ( ) Não soube relatar

Qual (is)?

Apresenta ou apresentou algum problema de saúde relacionado aos seguintes sistemas? ( ) sim ( ) não

1. ( ) Cardiovascular 2. ( ) Endócrino 3. ( ) Genito-urinário

4. ( ) Hematológico 5. ( ) Neurológico 6. ( ) Psiquiátrico

7. ( ) imunológico 8. ( ) Respiratório 9. ( ) Gastro-intestinal

10. ( ) Músculo/esquelético 11. ( ) Pele

12. ( ) Doenças infecto-contagiosas 13. ( ) Outros

14. ( ) Não apresenta problemas 16) ( ) História-familiar

Qual (is)?

Vícios:

1. Tabaco ( ) sim ( ) não

Fuma ( ) Masca ( ) Tipo

Há qto tempo? Qto/dia/semana?

Ex-tabagista? Há qto deixou? Qto/dia/semana?

2. Álcool ( ) sim ( ) não

Tipo

Há qto tempo?

Ex-alcoolista?

Há qto deixou?

Qto/dia/semana?

3. Outras drogas? ( ) sim ( ) não Qto/dia/semana?

Qto/dia/semana? 


\section{QUESTIONÁRIO DE SAÚDE BUCAL}

1. Sente a boca seca? ( ) sim ( ) não

2. Usa prótese removível?

Superior ( ) sim ( ) não Tipo :

Inferior ( ) sim ( ) não Tipo :

3. Há quanto usa prótese?

Superior

Inferior

4. Há quanto tempo é desdentado?

Superior

Inferior

5. Há quanto tempo usa a (s) prótese (s) atual (is) ?

Superior:

Inferior:

6. Freqüência de uso: Contínuo ( ) Esporádico ( )

Retira pra dormir? ( ) sim ( ) não

7. Condições da (s) prótese (s) atual (is)?

Suporte Adequado ( ) Inadequado ( )

Retenção Adequada ( ) Inadequada ( )

Estabilidade Adequada ( ) Inadequada ( )

Adaptação Adequada ( ) Inadequada ( )

8. Condições de higienização da (s) prótese (s)

Superior Boa ( ) Satisfatória ( ) Regular ( ) Insatisfatória ( )

Placa ( ) sim ( ) não Cálculo ( ) sim ( ) não

Inferior Boa ( ) Satisfatória ( ) Regular ( ) Insatisfatória ( )

Placa ( ) sim ( ) não Cálculo ( ) sim ( ) não

9. Condições de higiene bucal

Escovação da língua ( ) sim ( ) não

Higiene Bucal Boa ( ) Satisfatória ( ) Regular ( ) Insatisfatória ( )

10. Estomatite protética

Tipo de estomatite protética : I ( ) II ( ) III ( )

Sintomatologia dolorosa ( ) sim ( ) não 


\section{APÊNDICE D ORIENTAÇÕES}

\section{USO DO MEDICAMENTO IMUNO-MAX GEL}

Antes da aplicação do medicamento Imuno-Max Gel, você deve higienizar a sua boca e a sua dentadura como descrito a seguir:

1-. Escovar toda a cavidade bucal (gengiva, língua, bochecha e céu da boca), através de escova com creme dental.

20- Escovar a dentaura (parte de dentro e de fora), através de escova com creme dental.

Após higiene, este medicamento deve ser aplicado no céu da boca com cotonetes limpos. Fazer este procedimento 3 vezes ao dia, de 8/8 h, durante 14 dias.

Após a aplicação deste medicamento, colocar a dentadura sobre o céu da boca com o medicamento.

Obs: Em caso de dúvida, ligar a cobrar para Dr. Paulo Maurício Silva, através do número de telefone (91)8891-6860 ou (91) 3224-2073. 